Valguima Victoria Viana Aguiar Odakura

\title{
Localização de Markov para Multirrobôs Cooperativos
}

\author{
Tese apresentada à Escola Politécnica \\ da Universidade de São Paulo para \\ obtenção do Título de Doutor em Enge- \\ nharia Elétrica. \\ Área de concentração: \\ Sistemas Digitais \\ Orientador: \\ Profa. Dra. Anna Helena Reali \\ Costa
}


Este exemplar foi revisado e alterado em relação à versão original, sob responsabilidade única do autor e com a anuência de seu orientador.

São Paulo, 15 de fevereiro de 2007.

Assinatura do autor

Assinatura do orientador

\section{Ficha Catalográfica}

Odakura, Valguima Victoria Viana Aguiar

Localização de Markov para Multirrobôs Cooperativos. - ed. rev.

- São Paulo, Fevereiro de 2007. 127 p.

Tese (Doutorado) - Escola Politécnica da Universidade de São Paulo. Departamento de Engenharia de Computação e Sistemas Digitais.

1.Inteligência artificial 2.Robôs 3.Robótica (Inteligência artificial) Departamento de Engenharia de Computação e Sistemas Digitais. II. Título. 


\section{Agradecimentos}

Esta tese não teria chegado ao fim sem o apoio e incentivo de muitas pessoas, as quais tenho agora a oportunidade de agradecer.

À professora Anna Helena Reali Costa, por ter me orientado no decorrer deste trabalho, pela sua dedicação e paciência, e sobretudo pela sua valiosa contribuição para o meu amadurecimento.

Aos amigos e companheiros do Laboratório de Técnicas Inteligentes da Escola Politécnica da USP: Alexandre, Anarosa, André, Antônio, Diana, Inácio, Lucas, Luciano, Rodrigo e Valdinei que foram sempre muito companheiros e colaboraram de inúmeras maneiras durante esse período.

Aos professores Jaime Simão Sichman e Geraldo Lino de Campos da Escola Politécnica da USP, que acompanharam este trabalho, indicando os melhores caminhos a seguir. Ao professor Pedro Lima, do Instituto Superior Técnico de Lisboa, pela acolhida e pelos ensinamentos.

Ao Joe e ao André pelo apoio incondicional. Agradeço a confiança e oportunidade que vocês me propuseram.

Este trabalho não teria sido possível sem o apoio da FAPESP (processo número 01/14246-4), CAPES (processo BEX 0803/03-0), CNPq e pelo projeto Capes/Grices 099/03.

Às minhas amigas Ana Flavia, Eliany e Fátima, pelo companheirismo nos momentos felizes e nas dificuldades, pelo cuidado, pela paciência e pelas conversas.

Ao Reinaldo Bianchi pela fundamental colaboração na finalização deste trabalho, mas muito mais pela preciosa amizade construída ao longo desses anos.

Um agradecimento especial ao Fábio, pelo incentivo e apoio no tempo em que caminhamos juntos.

À minha família, minha mãe Daguimar e meu irmão Oswaldo, que são meu porto seguro em todas as situações.

Ao Maurício que pacientemente cuidou de mim no final deste trabalho e que tem me mostrado que é possível chegar ao todo juntando as partes. 


\section{Resumo}

Esta tese propõe um modelo probabilístico geral para a localização cooperativa de multirrobôs. O problema da localização multirrobôs pode ser definido como: dado um modelo do ambiente, estimar a localização de cada robô em um grupo atuando em um mesmo ambiente, com base nas informações sensoriais oferecidas pelas medidas de odometria, medidas do ambiente e detecções. Detecção é a habilidade de um robô identificar outro e determinar a distância relativa entre eles. A idéia principal da localização cooperativa de multirrobôs consiste em integrar medidas coletadas por diferentes robôs, de modo que todos possam se beneficiar dos dados adquiridos pelos outros robôs do grupo. Desta forma, detecções podem ser usadas para refinar a estimativa de postura de cada robô com base nas estimativas dos outros. Comunicação fornece aos robôs a habilidade de compartilhar suas crenças de postura de forma que possam cooperar para melhorar a acurácia da localização. Aqui é explorado o uso de diferentes tipos de informação para comunicar entre os robôs: propagação da detecção positiva, detecção negativa e multidetecção, os quais são integrados em um novo algoritmo, chamado Localização de Markov para Multirrobôs Cooperativos (LMMC). Também é proposto um protocolo de comunicação para a troca de dados entre os robôs e um conjunto de critérios que possibilitam a redução da comunicação por meio da diminuição da quantidade de dados trocados entre robôs, de um modo eficaz e eficiente. Os experimentos realizados em ambientes simulados demonstram que a abordagem proposta pode conduzir a resultados significativamente melhores de localização quando comparada à abordagem com detecção única e ainda com uma menor quantidade de mensagens trocadas entre os robôs. 


\section{Abstract}

In this thesis we propose a general probabilistic model to cooperative multirobot localization. The multirobot localization problem can be stated as follows: given a model of the environment, estimate the location of each robot in a group within the same environment based on sensors information that provides odometric measurements, environment measurements, and detections. Detection is the ability of one robot to identify others and to determine the relative location of other robots relative to its own. The key idea behind the multirobot localization approach is to integrate measurements taken by different robots, so that each one can benefit from data gathered by other robots in a group. In this sense, detections can be used to refine the pose estimates of a robot based on the other's estimate. Communication provides robots with the ability to exchange their pose beliefs, so that they can cooperate in order to improve their localization accuracy. We explore the use of different types of information to exchange among robots: propagation of positive detection, negative detection, and multidetection, which are integrated in a new algorithm, called Cooperative Multirobot Markov Localization, CMML. We also contribute a communication protocol that deals with the data transmitted among robots, and a set of communication rules that aims at reducing the amount of data exchanged among robots in an effective and efficient way. Experimental results, carried out in simulated environments, demonstrate that our approach can yield better localization results than a single-detection approach, at significantly smaller communication overhead. 


\section{Sumário}

Lista de Figuras

Lista de Tabelas

Lista de Abreviaturas

Lista de Símbolos

Lista de Algoritmos

1 Introdução 1

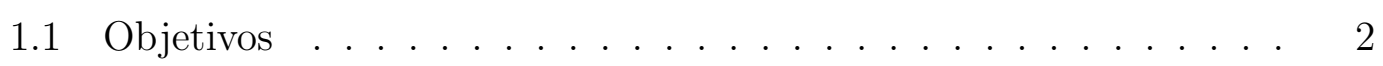

1.2 Contribuições . . . . . . . . . . . . . . . . . . 3

1.3 Organização da Tese . . . . . . . . . . . . . . . . . . 3

2 Localização de Robôs Móveis $\quad 5$

2.1 Robôs Móveis Autônomos . . . . . . . . . . . . . . 5

2.1.1 Sistema de Referência . . . . . . . . . . . . 8

2.1 .2 Sensores . . . . . . . . . . . . . . . . . 9

2.1.3 Locomoção . . . . . . . . . . . . . . . . . . . . 11

2.2 Representação do Ambiente . . . . . . . . . . . . . . . . . 12

2.3 Técnicas de Localização . . . . . . . . . . . . . . . . . . . . . . 14

2.4 Considerações Finais . . . . . . . . . . . . . . . . . 17

3 Técnicas Probabilísticas para Localização 18

3.1 Filtro de Kalman . . . . . . . . . . . . . . . . . . . . . . . 20

3.2 Localização de Markov . . . . . . . . . . . . . . . . . . 26 
3.3 Filtro de Partículas . . . . . . . . . . . . . . 30

3.4 Modelo de Arquitetura para Localização de um Robô . . . . . . . 32

3.5 Considerações Finais . . . . . . . . . . . . . . . . . . . 34

4 Localização para Multirrobôs Cooperativos 37

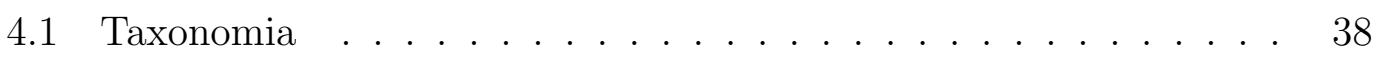

4.2 Trabalhos Relacionados . . . . . . . . . . . . . . . 39

4.3 Discussão dos Trabalhos Relacionados . . . . . . . . . . . . . 45

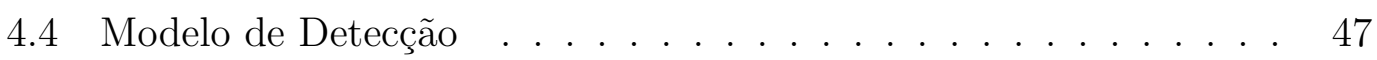

4.5 Modelo de Arquitetura para Localização de Multirrobôs . . . . . . 49

4.6 Representação Fatorada . . . . . . . . . . . . . . . . . . 51

4.7 Considerações Finais . . . . . . . . . . . . . . . . . . . . . . . . 54

5 Proposta do Modelo Geral de Detecção 55

5.1 Modelo de Detecção Negativa . . . . . . . . . . . . . . 56

5.2 Modelo de Propagação de Detecção Positiva . . . . . . . . . . . 58

5.3 Modelo de Multidetecção . . . . . . . . . . . . . . . . . . . . . 60

5.4 Algoritmo de Localização de Markov para Multirrobôs Cooperati$\operatorname{vos}-\mathrm{LMMC} \ldots \ldots \ldots \ldots 4 \ldots$

5.5 Discussão . . . . . . . . . . . . . . . . . . 6 65

6 Proposta do Modelo para Comunicação 68

6.1 Linguagens e Protocolos de Comunicação . . . . . . . . . . . . . 68

6.2 Modelo de Comunicação . . . . . . . . . . . . . . . . . . . . 69

6.3 Protocolo de Comunicação . . . . . . . . . . . . . . . . . . . 71

6.4 Reduzindo Comunicação . . . . . . . . . . . . . . . . . 73

6.5 Considerações Finais . . . . . . . . . . . . . . . . 78

$\begin{array}{lll}7 & \text { Experimentos } & 81\end{array}$

7.1 Modelo de Detecção Negativa . . . . . . . . . . . . . . . . 82 
7.2 Modelo de Propagação de Detecção Positiva . . . . . . . . . . . 85

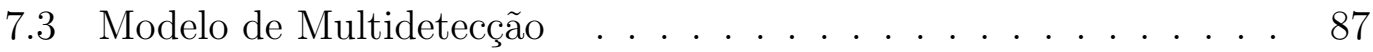

7.4 Integração dos Modelos . . . . . . . . . . . . . . . . . . . . . 97

7.5 Reduzindo Comunicação . . . . . . . . . . . . . . . . . . . . . . . 104

7.6 Discussão . . . . . . . . . . . . . . . . . . . . . . . 109

8 Conclusões e Trabalhos Futuros 115

8.1 Principais Contribuições e Limitações . . . . . . . . . . . . . . . 116

8.2 Trabalhos Futuros . . . . . . . . . . . . . . . . . . . 117

$\begin{array}{lr}\text { Referências Bibliográficas } & 119\end{array}$

$\begin{array}{lr}\text { Índice Remissivo } & 126\end{array}$ 


\section{Lista de Figuras}

2.1 Robô Pioneer 2DX equipado com 8 sonares e computador. . . . . 7

2.2 Sistemas de coordenadas do ambiente, do robô e dos sensores. . 9

2.3 Representações do ambiente: (a) grade de ocupação, (b) mapa geométrico e (c) mapa topológico. . . . . . . . . . . . . . . . . 13

3.1 O filtro de Kalman para localização. . . . . . . . . . . . . . . . . 21

3.2 Modelo de arquitetura para localização de um robô móvel. . . . . 33

4.1 Campo de visão de um robô. . . . . . . . . . . . . . . . . . . . . 48

4.2 Modelo de arquitetura para localização de multirrobôs. . . . . . . 49

5.1 Modelo de arquitetura para localização de multirrobôs. . . . . . . 56

5.2 (a) Informação de detecção negativa (área branca). (b) Oclusão no campo de visão (preto: obstáculo, cinza: informação de detecção negativa). . . . . . . . . . . . . . 57

5.3 Exemplo: posturas de 3 robôs. $R 1$ está certo sobre sua postura, $R 2$ está incerto sobre sua postura e $R 3$ está em dúvida sobre sua postura (as células cinzas). . . . . . . . . . . . . . . . . 59

5.4 Multidetecção: (a) Robô $R 1$ detecta $R 2, R 3$ e $R 4$ (linhas ao redor dos robôs $R 2, R 3$ e $R 4$ representam o campo de visão de $R 1$; (b) $R 1$ detecta $R 2, R 2$ detecta $R 3$ e $R 3$ detecta $R 4$, ao mesmo tempo.

5.5 Grafo representando oito robôs em a situação em que não ocorre detecção.

5.6 Grafo representando quatorze robôs em uma situação em que dois subgrupos de robôs participam de multidetecção.

5.7 Grafo representando a situação em que todos os quatro robôs detectam e são detectados uns pelos outros. 
5.8 Ordem de atualização das crenças de posturas: (a) Configuração dos robôs (b) $1^{o}:(R 2, R 3), 2^{o}:(R 1, R 2)$, e $3^{o}:(R 3, R 4)$. (b) $1^{o}$ : $(R 1, R 2)$ e $2^{\circ}:(R 3, R 4)$. . . . . . . . . . . . 64

6.1 Modelo de arquitetura para localização de multirrobôs. ..... 70

6.2 Grafo representando a situação em que dois subgrupos de robôs participam de multidetecção. . . . . . . . . . . . . . . . . 71

6.3 Protocolo de comunicação para o modelo geral de detecção. . . . . 79

6.4 Protocolo de comunicação para detecção com redução da comunicação. . . . . . . . . . . . . . . . . . 80

7.1 Ambientes de teste: (a) Duas salas simétricas (A e B) e um corredor C. (b) Ambiente aberto. (c) Ambiente de corredores (A, B, C e D). (d) Três salas. . . . . . . . . . . . . . . . . .

7.2 (a) Função densidade de probabilidade do robô $R 1$. (b) Função densidade de probabilidade do robô $R 2$. (c) Informação de detecção negativa comunicada pelo robô $R 1$. (d) Função densidade de probabilidade do robô $R 2$ após incorporar a informação de detecção negativa. . . . . . . . . . . . . . . . . .

7.3 Comparação entre LMM e LMM acrescido do modelo de detecção negativa com três robôs no ambiente simétrico da Figura 7.1(a).

(a) Erros de localização. (b) Resultado do teste $t$ de Student. . . . 86

7.4 Comparação entre LMM e LMM acrescido do modelo de propagação da detecção positiva com três robôs no ambiente simétrico da Figura 7.1(a). (a) Erros de localização. (b) Resultado do teste t de Student. . . . . . . . . . . . . . . . . 88

7.5 Comparação entre LMM e LMM acrescido do modelo de propagação da detecção positiva com quatro robôs no ambiente aberto da Figura 7.1(b). (a) Erros de localização. (b) Resultado do teste

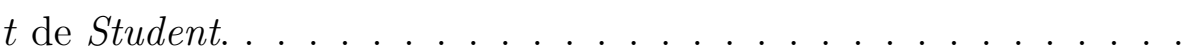

7.6 Comparação entre LMM e LMM acrescido do modelo de propagação da detecção positiva com oito robôs no ambiente de corredores da Figura 7.1(c). (a) Erros de localização. (b) Resultado do teste $t$ de Student. . . . . . . . . . . . . . . . . . . 
7.7 Comparação entre LMM e LMM acrescido do modelo de propagação da detecção positiva com dez robôs no ambiente de salas da Figura 7.1(d) com 10 robôs. (a) Erros de localização. (b) Resultado do teste $t$ de Student. . . . . . . . . . . . . . . . . . . 91

7.8 Comparação entre LMM e LMM acrescido do modelo de multidetecção com três robôs no ambiente simétrico da Figura 7.1(a). (a) Erros de localização. (b) Resultado do teste $t$ de Student. . . . . .

7.9 Comparação entre LMM e LMM acrescido do modelo de multidetecção com quatro robôs no ambiente aberto da Figura 7.1(b).(a) Erros de localização. (b) Resultado do teste $t$ de Student. . . . . .

7.10 Comparação entre LMM e LMM acrescido do modelo de multidetecção com 8 robôs no ambiente de corredores da Figura 7.1(c). (a) Erros de localização. (b) Resultado do teste $t$ de Student. . . .

7.11 Comparação entre LMM e LMM acrescido do modelo de multidetecção com dez robôs no ambiente de salas da Figura 7.1(d). (a) Erros de localização. (b) Resultado do teste $t$ de Student. . . . . .

7.12 Comparação entre três ordens de atualização das crenças de posturas no ambiente simétrico da Figura 7.1(a) com 3 robôs. Ordem 1 - menor entropia (proposta), Ordem 2 - maior entropia, Ordem 3 - numérica.

7.13 Comparação entre três ordens de atualização das crenças de posturas no ambiente aberto da Figura 7.1(b) com 4 robôs. Ordem 1 - menor entropia (proposta), Ordem 2 - maior entropia, Ordem 3 - numérica.

7.14 Comparação entre três ordens de atualização das crenças de posturas no ambiente de corredores da Figura 7.1(c) com 8 robôs. Ordem 1 - menor entropia (proposta), Ordem 2 - maior entropia, Ordem 3 - numérica

7.15 Comparação entre três ordens de atualização das crenças de posturas no ambiente de salas da Figura 7.1(d) com 10 robôs. Ordem 1 - menor entropia (proposta), Ordem 2 - maior entropia, Ordem 3 - numérica. 
7.16 Comparação entre LMM e LMM acrescido dos modelos de detecção negativa e propagação da detecção positiva com três robôs no ambiente simétrico da Figura 7.1(a). (a) Erros de localização. (b) Resultado do teste $t$ de Student. . . . . . . . . . . . . . . . . . . 100

7.17 Comparação entre LMM e LMM acrescido dos modelos de detecção negativa e propagação da detecção positiva com quatro robôs no ambiente aberto da Figura 7.1(b). (a) Erros de localização. (b) Resultado do teste $t$ de Student. . . . . . . . . . . . . . . . 101

7.18 Comparação entre LMM e LMM acrescido dos modelos de detecção negativa e propagação da detecção positiva com oito robôs no ambiente de corredores da Figura 7.1(c). (a) Erros de localização. (b) Resultado do teste $t$ de Student. . . . . . . . . . . . . . . . . 102

7.19 Comparação entre LMM e LMM acrescido dos modelos de detecção negativa e propagação da detecção positiva com dez robôs no ambiente de salas da Figura 7.1(d). (a) Erros de localização. (b) Resultado do teste $t$ de Student. . . . . . . . . . . . . . . . . 103

7.20 Comparação entre LMM e LMM acrescido dos modelos de multidetecção e detecção negativa com três robôs no ambiente simétrico da Figura 7.1(a). (a) Erros de localização. (b) Resultado do teste t de Student. . . . . . . . . . . . . . . . . . . . . . . 105

7.21 Comparação entre LMM e LMM acrescido dos modelos de multidetecção e detecção negativa com quatro robôs no ambiente aberto da Figura 7.1(b). (a) Erros de localização. (b) Resultado do teste $t$ de Student.

7.22 Comparação entre LMM e LMM acrescido dos modelos de multidetecção e detecção negativa com oito robôs no ambiente de corredores da Figura 7.1(c). (a) Erros de localização. (b) Resultado do teste $t$ de Student.

7.23 Comparação entre LMM e LMM acrescido dos modelos de multidetecção e detecção negativa com dez robôs no ambiente de salas da Figura 7.1(d). (a) Erros de localização. (b) Resultado do teste $t$ de Student.

7.24 Comparação entre técnicas mais e menos comunicativas com três robôs no ambiente simétrico da Figura 7.1(a). (a) Detecção. (b) Multidetecção. 
7.25 Comparação entre técnicas mais e menos comunicativas com quatro robôs no ambiente aberto da Figura 7.1(b). (a) Detecção. (b) Multidetecção. . . . . . . . . . . . . . . . . . 111

7.26 Comparação entre técnicas mais e menos comunicativas com oito robôs no ambiente de corredores da Figura 7.1(c). (a) Detecção. (b) Multidetecção. . . . . . . . . . . . . . . . . . . . . . . 112

7.27 Comparação entre técnicas mais e menos comunicativas com dez robôs no ambiente de salas da Figura 7.1(d). (a) Detecção. (b) Multidetecção. . . . . . . . . . . . . . . . . . . . . . . . . . 113 


\section{Lista de Tabelas}

3.1 Equações do Filtro de Kalman Discreto. . . . . . . . . . . . . . 23

3.2 Equações do Filtro de Kalman Estendido. . . . . . . . . . . . . . 25

3.3 Comparação de algoritmos para localização de robôs. . . . . . . . 35

4.1 Classificação de trabalhos de localização cooperativa de multirrobôs. . . . . . . . . . . . . . . . . . 4 46

6.1 Condições para redução da comunicação. . . . . . . . . . . . . . . 77

7.1 Resumo dos experimentos de comparação entre LMM e modelos propostos na tese, referência as figuras dos experimentos correspondentes. . . . . . . . . . . . . . . . . 104

7.2 Resumo dos experimentos de redução de comunicação para os casos de detecção e multidetecção. ............. 109 


\section{Lista de Abreviaturas}

CCD Dispositivo de carga acoplada (Charge Coupled Device)

FIPA ACL Fundação para Agentes Físicos Inteligentes - Linguagem de Comunicação de Agentes (Foundation for Intelligent Physical Agents AgentCommunication Language)

FK Filtro de Kalman

FKE Filtro de Kalman Estendido

FP Filtro de Partículas

KQML Linguagem de Manipulação e Pergunta de Conhecimento (Knowledge Query and Manipulation Language)

LCA Linguagem de Comunicação de Agentes

LM Localização de Markov

LMC Localização Monte Carlo

LMM Localização de Markov para Multirrobôs

LMMC Localização de Markov para Multirrobôs Cooperativos

MAP Máximo a Posteriori

MC Modelo de Comunicação

MD Modelo de Detecção

MGD Modelo Geral de Detecção

MLE Estimação por Verossimilhança Máxima (Maximum Likelihood Estimation)

MM Modelo de Movimento

MO Modelo de Observação 


\section{Lista de Símbolos}

$\left(X^{A}, Y^{A}\right)$ - Sistema de coordenadas do ambiente.

$\left(X^{R}, Y^{R}\right)$ - Sistema de coordenadas do robô.

$\left(X^{S}, Y^{S}\right)$ - Sistema de coordenadas do sensor.

$\mathbf{u}(t)$ - Comandos de movimento do robô no tempo $t$.

$x=(\mathrm{x}, \mathrm{y}, \theta)$ - Postura do robô no sistema de coordenadas do ambiente.

$(\mathrm{x}, \mathrm{y})$ - Posição do robô no sistema de coordenadas do ambiente.

$\mathbf{x}_{t}$ - Variável aleatória da postura do robô no tempo $t$.

$p\left(\mathbf{x}_{t}\right)$ - Distribuição de probabilidade da postura do robô no tempo $t$.

$\mathbf{o}_{t}$ - Observação dos sensores externos, observação positiva do ambiente no tempo

$t$.

$\mathbf{a}_{t}$ - Observação dos sensores internos no tempo $t$.

$d_{t}$ - Conjunto de leituras dos sensores até o tempo $t$.

$p\left(\mathbf{x}_{t}=x\right)$ - Crença que o robô atribui para a possibilidade de estar na postura $x$ no tempo $t$.

$\mathbf{o}_{t}^{-}-$Observação negativa do ambiente no tempo $t$.

$\mathbf{v}$ - Área de visibilidade do robô.

obs - Obstáculos identificados.

$n, m, k$ - Identificadores de robôs.

$\mathbf{x}_{t}^{n}$ - Variável aleatória da postura do robô $n$ no tempo $t$.

$p\left(\mathbf{x}_{t}^{n}=x\right)$ - Crença que o robô $n$ atribui para a possibilidade de estar na postura $x$ no tempo $t$.

$\mathbf{r}_{t}^{n}$ - Distância relativa entre os dois robôs, como medida pelo robô $n$ no tempo $t$.

$\mathbf{d}_{t}^{-}-$Evento de não detectar nenhum robô no tempo $t$.

$\mathbf{v}^{n}$ - Área de visibilidade do robô $n$.

obs - Obstáculos identificados.

$G(V, E)$ - Grafo com vértices $V$ e arestas $E$.

$M$ - Número de robôs do grupo.

$H$ - Valor de entropia de $p(\mathbf{x})$.

$H_{i j}$ - Valor de entropia do encontro dos robôs $R_{i}$ e $R_{j}$.

$C_{j}=\left(V_{C_{j}}, E_{C_{j}}^{\prime}\right)$ para $j=1, \cdots, N_{c}$ - Componentes conexos do grafo $G$.

$N_{c}$ - Número de componentes conexos de $G$.

$T$ - Valor testado no teste $t$ de Student. 
$t_{\alpha}$ - Nível de confiança do teste $t$ de Student. 


\title{
Lista de Algoritmos
}

\author{
1 Localização de Markov - LM \\ 2 Filtro de Partículas - FP \\ 3 Localização de Markov para Multirrobôs - LMM \\ 4 Localização de Markov para Multirrobôs Cooperativos - LMMC
}




\section{Introdução}

A navegação de robôs móveis autônomos é uma área de pesquisa com muitos desafios e inúmeros problemas não solucionados. A pesquisa na área é motivada pela esperança de que robôs possam fazer parte do dia-a-dia das pessoas, realizando diversas tarefas, tanto serviços como entretenimento, atuando em casas, escritórios, hospitais e indústrias.

Navegar em um ambiente envolve as tarefas de localização, construção de mapa e planejamento de trajetória. A idéia básica da localização de robôs móveis é combinar medidas de sensores internos, que fornecem informação sobre o movimento do robô, com sensores externos, que fornecem informação do ambiente. As informações sensoriais são comparadas com um mapa conhecido a priori, resultando na informação de posicionamento do robô em relação ao ambiente no qual está inserido. No entanto, as informações que os robôs recebem de seus sensores são incertas. No caso de sensores externos, as medidas não são acuradas e são ruidosas e estão limitadas pelo fato dos sensores, em geral, poderem medir apenas parte do ambiente. Para os sensores internos, o controle dos atuadores, no caso, dispositivos responsáveis pela locomoção do robô, também não são acurados. Desta maneira é necessário fundir medidas de diferentes sensores, obtidas em posturas e tempos distintos, de modo a obter uma melhor estimativa da localização de robôs móveis.

A pesquisa em sistemas multirrobôs é ainda mais atrativa pois um grupo de robôs móveis atuando de forma cooperativa pode executar tarefas mais complexas, percorrer uma área maior do que um único robô e ainda, pode ser mais barato construir vários robôs simples do que um único robô complexo. Desta forma, sendo a localização uma tarefa fundamental para que robôs consigam atuar de forma autônoma, deve-se considerar a localização para multirrobôs.

Na localização para multirrobôs, além da fusão de informações dos diferentes sensores de um mesmo robô, é necessário fundir informações provenientes dos sensores de outros robôs do grupo. A comunicação entre os robôs possibilita que estes compartilhem informações úteis para a localização, de maneira que 
todos os robôs do grupo melhorem suas estimativas de postura. A cooperação na localização para multirrobôs ocorre de maneira semelhante ao que acontece com seres humanos. Se uma pessoa está perdida e não consegue, apenas com a observação do ambiente, encontrar sua localização, esta pode pedir ajuda para outra pessoa que, sabendo onde está, pode ajudar na tarefa de localização.

A cooperação entre os robôs envolve as questões: o quê, quando e para quem comunicar. A maioria das técnicas de localização para multirrobôs existentes são guiadas por detecções, ou seja, a comunicação acontece quando um robô detecta e identifica outro, e mede a distância relativa entre eles. Os robôs envolvidos na detecção comunicam suas crenças de postura e a informação de distância e utilizam estas informações para atualizar suas crenças de posturas.

Este é o ponto de partida de investigação nesta tese: explorar a cooperação entre robôs através de troca de informações úteis para a tarefa de localização, de forma a melhorar a qualidade das estimativas de posturas dos robôs.

\subsection{Objetivos}

O objetivo principal da tese é propor uma solução para o problema de localização para multirrobôs cooperativos, que contribua para melhorar a acurácia das estimativas de posturas de todos os robôs do grupo. Para tal é explorada a cooperação entre os robôs, que ocorre através da comunicação de informações que auxiliam na tarefa de localização. Desta forma, os objetivos gerais da tese compreendem:

- Investigar quais informações os robôs podem compartilhar para contribuir na melhora de suas estimativas de postura e propor novas formas de atualização de postura com informação proveniente do grupo.

- Reduzir a quantidade de informação comunicada pelos robôs. Para isso, avaliar a relação entre a quantidade de informação comunicada entre os robôs e a melhora na qualidade das estimativas das posturas dos robôs.

- Propor uma técnica para solucionar o problema de localização para multirrobôs cooperativos que incorpore as soluções encontradas nos dois itens anteriores. 


\subsection{Contribuições}

Com base nos objetivos propostos, as contribuições alcançadas no decorrer do desenvolvimento desta tese foram:

- Proposta de novas formas de atualização das crenças das posturas dos robôs com informações de propagação da informação de detecção positiva, detecção negativa e multidetecção.

- Proposta de uma técnica de localização para multirrobôs chamada de Localização de Markov para Multirrobôs Cooperativos (LMMC).

- Proposta de um protocolo de comunicação para lidar com as trocas de mensagens da LMMC.

- Redução da quantidade de informação comunicada entre robôs através da restrição da comunicação considerando como critério a utilidade da informação comunicada.

- Melhores resultados de localização para multirrobôs quando comparados com aqueles algoritmos utilizando técnicas anteriormente propostas na literatura.

\subsection{Organização da Tese}

Para solucionar o problema de localização de robôs móveis é necessário entender o que é um robô móvel, como funciona, quais são os problemas relacionados com a navegação do robô no ambiente, entre outros. Para responder estas questões, no Capítulo 2, a área de robótica móvel é introduzida, com ênfase na tarefa de localização.

A localização de robôs móveis depende das informações obtidas pelos sensores, que são incertas. Para lidar com a incerteza inerente da localização são utilizadas técnicas probabilísticas. As principais técnicas probabilísticas para localização de robôs móveis são descritas no Capítulo 3.

Para que um grupo de robôs possa se localizar em um mesmo ambiente de forma cooperativa, estes trocam informações quando um detecta o outro e mede a distância relativa entre eles. As técnicas de localização para multirrobôs cooperativos são apresentadas no Capítulo 4. 
Os robôs podem compartilhar mais do que apenas a informação da detecção envolvendo um par de robôs. O acréscimo de outras formas de estimar as posturas dos robôs utilizando informação comunicada pelo grupo é descrito no Capítulo 5, onde um modelo geral de detecção é proposto. O algoritmo de localização resultante, chamado LMMC também é apresentado.

Para que os robôs compartilhem informações seguindo o modelo geral de detecção é preciso adaptar o modelo de comunicação. Isto é feito com uma proposta de um protocolo de comunicação. Além disso, o aumento de informações compartilhadas entre os robôs aumenta a quantidade de comunicação e o processamento das atualizações das crenças de posturas dos robôs. Uma forma de reduzir a quantidade de informação comunicada baseada na utilidade é proposta, o que resulta em um protocolo de comunicação adaptado. Estas contribuições são descritas no Capítulo 6.

Os experimentos realizados para ilustrar a LMMC proposta nesta tese são apresentados no Capítulo 7, em que são comparadas a localização de Markov para multirrobôs e a LMMC.

Por fim, no Capítulo 8 são apresentadas as conclusões referentes a esta tese, bem como os possíveis trabalhos futuros. 


\section{Localização de Robôs Móveis}

Neste capítulo são introduzidos alguns conceitos da área de robótica móvel, especificamente para a tarefa de localização de robôs móveis. A localização, que consiste em encontrar a postura do robô em relação a uma ambiente, é uma tarefa fundamental para que robôs móveis consigam agir de maneira autônoma.

Para iniciar o estudo da robótica móvel é necessário definir o que é um robô móvel, bem como quais são os mecanismos que permitem com que se locomova e observe o ambiente que o cerca, temas abordados na Seção 2.1. Robôs móveis são capazes de navegar no ambiente, o que envolve as tarefas de representação do ambiente e localização do robô, apresentadas nas Seções 2.2 e 2.3, respectivamente. Por fim, as considerações finais são apresentadas na Seção 2.4.

\subsection{Robôs Móveis Autônomos}

A robótica móvel é uma área de pesquisa que gera muito interesse e que tem sido bastante investigada, como pode ser percebido pela vasta e diversa literatura a respeito. Além dos inúmeros artigos que tratam das diferentes tarefas envolvidas no desenvolvimento de robôs móveis, existem alguns livros recentes que abordam os fundamentos da robótica móvel, como Nehmzow (1999), Dudek e Jenkin (2000), Murphy (2000), Siegwart e Nourbakhsh (2004) e Thrun, Burgard e Fox (2005).

A riqueza e diversidade de linhas de pesquisa que emergem da robótica móvel podem ser percebidas no texto de Nehmzow (1999):

"Transformar um robô de um computador sobre rodinhas, capaz meramente de perceber algumas propriedades físicas do ambiente através de seus sensores, em um agente inteligente, capaz de identificar atributos, detectar padrões e regularidades, aprender a partir de experiência, localizar-se, construir mapas e navegar, necessita da aplicação si- 
multânea de muitas disciplinas de pesquisa. Neste sentido, a robótica móvel revoga a tendência da ciência em relação a mais e mais especialização, e reivindica o pensamento lateral ${ }^{1}$ e a combinação de muitas disciplinas."

Para iniciar o estudo da robótica móvel é necessário definir o que é um robô. A palavra robô vem do checo robota, que significa "trabalho forçado", e foi usada pela primeira vez com o sentido de uma máquina automática pelo escritor Karel Capek em 1921 em sua peça "R.U.R." (Rossumovi Univerzálni Roboti)", segundo Nehmzow (1999). Atualmente existem diversas definições para um robô, mais elaboradas que sua versão original. Por exemplo, para o dicionário Cambridge (2006), um robô é:

"Uma máquina usada para realizar tarefas automaticamente, que é controlada por computador."

Existem inúmeros tipos e modelos de robôs em produção no mundo, que variam em forma, tamanho, velocidade, entre outras características. Uma possível maneira de se classificar os robôs é com base na aplicação para qual foram projetados. Neste caso, uma primeira distinção que é geralmente feita é entre os manipuladores industriais fixos e os robôs móveis.

Os manipuladores industriais são utilizados na indústria para realizar tarefas de montagem, pintura, solda, manipulação, entre outras. Tais robôs são programados para uma tarefa específica, como empacotamento de produtos, e não necessitam possuir capacidades de locomoção.

No entanto, uma variedade maior de tarefas podem ser realizadas quando os robôs possuem capacidade de locomoção. Por exemplo, robôs para busca e salvamento, para entrega de correspondência ou remédios e robôs para limpeza.

Segundo Nehmzow (1999), um robô móvel pode ser definido como um robô que pode mudar sua localização por meio de locomoção. Um dos temas principais tratados pela disciplina de robótica móvel é o controle de robôs móveis autônomos. Os robôs móveis podem ou não ser autônomos: a autonomia do robô está relacionada com a capacidade do robô adaptar-se às mudanças no ambiente e na tarefa; isto implica um robô capaz de determinar suas ações pelo seu próprio processo de raciocínio, ao invés de seguir instruções definidas por agentes externos.

\footnotetext{
${ }^{1}$ um meio de solucionar um problema pensando sobre ele imaginativa e originalmente e não usando métodos tradicionais ou esperados (CAMBRIDGE, 2006).
} 
Desta forma, um robô móvel autônomo tem a capacidade de movimentarse no ambiente em que estiver inserido, perceber o ambiente através de seus sensores, adaptar-se às mudanças no ambiente, aprender a partir de experiências, construir representações internas do seu ambiente que possam ser usadas no seu processo de tomada de decisão.

Um robô móvel pode ser considerado por uma perspectiva diferente. Em um nível físico, segundo Dudek e Jenkin (2000), um robô pode ser decomposto em:

- Um mecanismo para fazer o robô locomover-se pelo ambiente.

- Um ou mais computadores para controlar o robô.

- Uma coleção de sensores com os quais o robô obtém informação do ambiente.

- Dispositivos de comunicação que possibilitem que o robô se comunique com computadores externos, por exemplo outros robôs, ou com seres humanos.

Um robô móvel pode ser visto na Figura 2.1. Neste robô é possível identificar as rodas, que são responsáveis por sua locomoção, o computador, utilizado para controlá-lo, os sensores, oito sonares frontais e laterais, utilizados para sensoriar o ambiente.

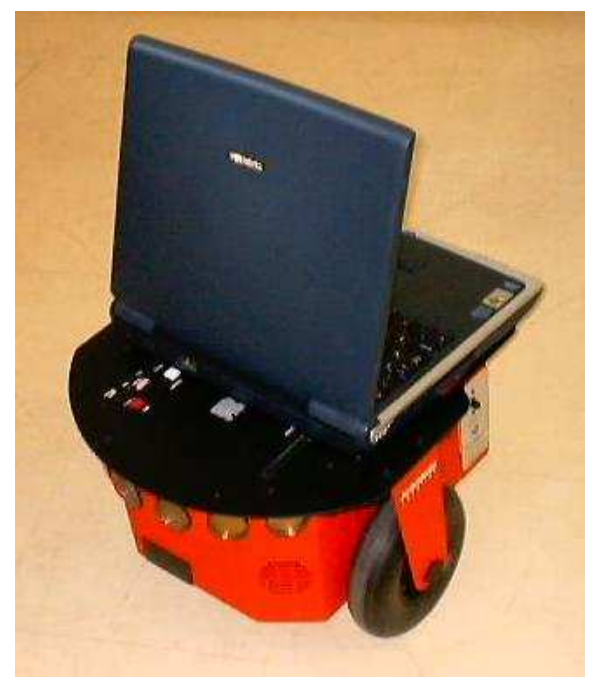

Figura 2.1: Robô Pioneer 2DX equipado com 8 sonares e computador.

A principal capacidade exigida de um robô móvel é a de navegação no ambiente em que ele está inserido. A navegação de robôs móveis é a capacidade do robô movimentar-se dentro de um ambiente, sendo capaz de atingir uma posição objetivo, enquanto desvia de obstáculos que podem ser encontrados no seu caminho. Segundo Nehmzow (1999), a navegação de robôs móveis está relacionada 
com a realização de três tarefas: localização, construção de mapas e planejamento de trajetórias.

O problema de encontrar sua própria posição no ambiente é chamado de localização ou auto-localização do robô. Muitas vezes esta tarefa é auxiliada pelo conhecimento de um mapa do ambiente no qual o robô está inserido. Um mapa é uma representação interna do ambiente do robô. A construção do mapa pelo próprio robô está baseada na observação e exploração do ambiente. Para atingir uma posição objetivo o robô precisa planejar um caminho até o objetivo. Planejamento de caminho consiste em determinar um caminho no ambiente, entre a posição inicial e a posição objetivo, tal que o robô não colida com nenhum obstáculo do ambiente e que os movimentos planejados sejam consistentes com as restrições físicas do robô.

Nas seções seguintes são apresentadas algumas características a respeito de robôs móveis, como: sistema de referência no qual a navegação dos robôs é baseada; os sensores utilizados para obter informações sobre a localização dos robôs no ambiente; e os mecanismos de locomoção utilizados por robôs móveis com rodas, respectivamente nas Subseções 2.1.1, 2.1.2 e 2.1.3.

\subsubsection{Sistema de Referência}

Um robô móvel precisa de um ponto de referência no qual é baseada sua navegação, ou seja, um sistema de referência. Um sistema de referência pode ser um sistema de coordenadas cartesianas. Neste caso, o sistema de referência é o sistema de coordenadas do ambiente ou sistema de coordenadas global, com eixos denominados $\left(X^{A}, Y^{A}\right)$, no caso de locomoção sobre um plano. $\mathrm{O}$ robô possui seu próprio sistema de coordenadas, centrado no robô, chamado de sistema de coordenadas do robô, com eixos $\left(X^{R}, Y^{R}\right)$. Os sensores do robô, por sua vez, possuem seu próprio sistema de coordenadas, centrado no sensor, denominado sistema de coordenadas do sensor, com eixos $\left(X^{S}, Y^{S}\right)$. Os sistemas de coordenadas envolvidos na navegação de robôs móveis podem ser vistos na Figura 2.2.

Quando o robô realiza uma medida do ambiente com um sensor, esta medida é feita em relação ao sistema de coordenadas do sensor. No entanto, o mapa do ambiente armazena informações em relação às coordenadas do ambiente. Assim, para realizar uma correspondência entre estas duas informações é necessária uma mudança de coordenadas. A mudança de coordenadas do sistema do sensor para 


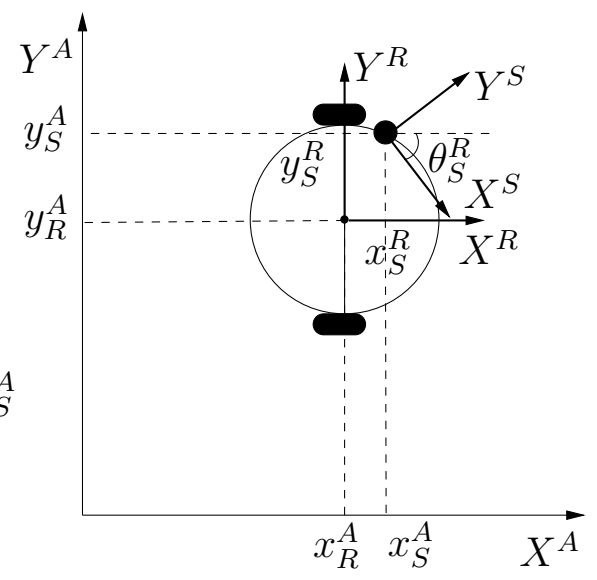

Figura 2.2: Sistemas de coordenadas do ambiente, do robô e dos sensores.

o sistema do ambiente é dada por:

$$
\left[\begin{array}{c}
x_{S}^{A} \\
y_{S}^{A} \\
\theta_{S}^{A}
\end{array}\right]=\left[\begin{array}{c}
x_{R}^{A} \\
y_{R}^{A} \\
\theta_{R}^{A}
\end{array}\right]+\left[\begin{array}{ccc}
\cos \left(\theta_{R}^{A}\right) & -\sin \left(\theta_{R}^{A}\right) & 0 \\
\sin \left(\theta_{R}^{A}\right) & \cos \left(\theta_{R}^{A}\right) & 0 \\
0 & 0 & 1
\end{array}\right]\left[\begin{array}{c}
x_{S}^{R} \\
y_{S}^{R} \\
\theta_{S}^{R}
\end{array}\right]
$$

onde $\left(x_{S}^{A}, y_{S}^{A}, \theta_{S}^{A}\right)$ são as coordenadas do sensor no sistema de coordenadas do ambiente, $\left(x_{R}^{A}, y_{R}^{A}, \theta_{R}^{A}\right)$ são as coordenadas do robô no sistema de coordenadas do ambiente e $\left(x_{S}^{R}, y_{S}^{R}, \theta_{S}^{R}\right)$ são as coordenadas do sensor no sistema de coordenadas do robô.

\subsubsection{Sensores}

Um robô móvel observa o ambiente através de seus sensores. Tais sensores podem ser divididos em internos e externos. Sensores internos medem informações referentes aos estados internos do robô, como movimento, aceleração e direção. Alguns sensores internos são:

Odômetro: mede a informação de movimento do robô, no caso do robô equipado com rodas. A informação de odometria é obtida contando o número de rotações das rodas acopladas ao robô. Esta informação possui erros causados por diâmetro desigual ou não alinhamento das rodas, ou ainda, por deslizamento ou derrapagens das mesmas.

Inercial: mede a segunda derivada da postura, ou seja, a aceleração e a aceleração angular do robô, e são, respectivamente, acelerômetro e giroscópio.

Bússola: fornece medida de direção. Utiliza o campo magnético da Terra para encontrar a direção. Este sensor sofre de desvios causados por grande 
quantidade de metal, que é normalmente encontrado em robôs e em determinados ambientes onde atuam, e campos magnéticos gerados por correntes elétricas, existentes nos ambientes de atuação dos robôs.

Sensores externos fornecem informações sobre o ambiente que cerca o robô, por exemplo, distância ou forma de objetos. Alguns sensores externos são:

Sonar: mede distâncias a objetos que se encontram na faixa de dezenas de centímetros a alguns metros do robô. O sonar emite pulsos de som em uma determinada freqüência. Um pulso é refletido ao encontrar um objeto e, com base no tempo necessário para que o pulso refletido seja detectado pelo sonar, estima-se a distância ao objeto que produziu a reflexão.

Infravermelho: fornece informações sobre a presença de objetos em curtas distâncias, alguns centímetros. Opera emitindo raios de luz infravermelhos e detectando as reflexões dos raios emitidos.

Laser: fornece informações acuradas sobre a presença de objetos em longas distâncias, dezenas de metros. Emite um pulso de luz e pelo tempo gasto entre a emissão e a detecção do retorno do pulso, determina a distância aos objetos.

Câmera: a maioria das câmeras utilizam sensores do tipo Dispositivo de carga acoplada (Charge Coupled Device) (CCD). Estas câmeras fornecem matrizes numéricas que correspondem à distribuição da intensidade de luz refletida pelo ambiente e capturada em uma imagem, que pode ser monocromática ou colorida. Uma matriz de imagem possui muitas informações sobre o ambiente, o que pode significar muito tempo de processamento para a extração de tais informações.

As leituras dos sensores externos são chamadas de observação ou percepção, pois designam a observação do robô acerca do seu ambiente.

A maior parte dos sensores reais, internos ou externos, são ruidosos, retornam uma descrição incompleta do ambiente, e não podem ser modelados completamente. Estas questões devem ser consideradas durante o desenvolvimento de um sistema de navegação robótico. Uma descrição detalhada dos diversos sensores empregados por robôs móveis é apresentada por Borenstein, Everett e Feng (1996). 


\subsubsection{Locomoção}

Robôs móveis podem locomover-se em ambientes terrestre, aquático, aéreo e espacial. Para cada um dos ambientes são necessários dispositivos diferentes de locomoção. Robôs que atuam em ambiente terrestre exploram o contato com o chão para se movimentar. Apesar do robô com rodas ser o mais comum, existem robôs que se locomovem através de hastes, pernas ou lagartas. Nesta seção são considerados dois tipos de robôs sobre rodas, o robô com direção diferencial e o robô com direção síncrona.

Dois problemas diferentes estão relacionados com a locomoção de robôs móveis: o problema da cinemática direta e o problema da cinemática inversa. O problema da cinemática direta consiste em saber como o robô se movimenta, dados os comandos de movimento. O problema da cinemática inversa consiste em encontrar quais os comandos de movimento que resultarão no movimento desejado. Conhecer o modelo cinemático direto do robô é fundamental para a tarefa de localização de robôs. Dada $\left(\mathrm{x}_{0}, \mathrm{y}_{0}, \theta_{0}\right)$, a postura inicial do robô correspondente às coordenadas do robô no sistema de coordenadas do ambiente no instante inicial, é possível computar a postura do robô no tempo $t$, dados os comandos de movimento do robô executados até o instante $t$. Este problema possui uma solução geral, para um robô que pode movimentar-se em uma velocidade angular $\omega(t)$ com uma velocidade $v(t)$, segundo Dudek e Jenkin (2000), dada por:

$$
\begin{aligned}
& \mathrm{x}(t)=\int_{0}^{t} v(t) \cos (\theta(t)) d t \\
& \mathrm{y}(t)=\int_{0}^{t} v(t) \sin (\theta(t)) d t \\
& \theta(t)=\int_{0}^{t} \omega(t) d t
\end{aligned}
$$

Um robô com direção diferencial consiste de duas rodas montadas em um eixo comum, controladas por dois motores separados. Em geral, uma terceira roda de apoio é necessária para manter o equilíbrio do robô. As rodas possuem movimento apenas em uma direção, no eixo perpendicular ao eixo das rodas. Um robô com direção diferencial controla sua postura fornecendo comandos independentes de movimento para cada uma das rodas. Se as velocidades forem iguais para as duas rodas, o robô movimenta-se linearmente, caso contrário, o robô apresenta movimentos curvilíneos. Os comandos de movimento podem ser denotados por $\mathbf{u}(t)=\left[\Delta D_{d}(t) \quad \Delta D_{e}(t)\right]$, em que $\Delta D_{d}(t)$ e $\Delta D_{e}(t)$ são as distâncias percorridas pelas rodas direita e esquerda no intervalo de tempo $t$ até $t+1$, empregando 
as velocidades $v_{d}(t)$ e $v_{e}(t)$, nas rodas direitas e esquerda, respectivamente. A distância percorrida pelo robô e o ângulo de inclinação podem ser calculados por:

$$
\begin{aligned}
\Delta D(t) & =\frac{\Delta D_{d}(t)+\Delta D_{e}(t)}{2} \quad \mathrm{e} \\
\Delta \theta(t) & =\frac{\Delta D_{d}(t)-\Delta D_{e}(t)}{L},
\end{aligned}
$$

onde $L$ é o comprimento do eixo entre as duas rodas. Desta forma, a atualização da postura do robô pode ser definida, seguindo a Equação 2.2, geral da cinemática, como:

$$
\left[\begin{array}{l}
\mathrm{x}(t+1) \\
\mathrm{y}(t+1) \\
\theta(t+1)
\end{array}\right]=\left[\begin{array}{l}
\mathrm{x}(t) \\
\mathrm{y}(t) \\
\theta(t)
\end{array}\right]+\left[\begin{array}{c}
\Delta D(t) \cos (\theta(t))) \\
\Delta D(t) \sin (\theta(t))) \\
\Delta \theta(t)
\end{array}\right] .
$$

Num robô com direção síncrona, as rodas possuem dois motores independentes, um para controlar o movimento para frente e outro para controlar a rotação. Todas as rodas apontam para a mesma direção e movimentam-se com a mesma velocidade. Uma configuração comum envolve três rodas dispostas na forma de um triângulo equilátero. Os comandos de movimento podem ser denotados por $\mathbf{u}(t)=[\Delta D(t) \quad \Delta \theta(t)]$, em que $\Delta D(t)$ e $\Delta \theta(t)$ são a distância percorrida pelo robô e o ângulo de inclinação no intervalo de tempo $t$ até $t+1$, respectivamente. Desta forma, a atualização da postura do robô pode ser calculada como na Equação 2.5.

Maiores informações sobre sistemas de locomoção podem ser encontradas nos textos de Borenstein, Everett e Feng (1996) e Dudek e Jenkin (2000).

\subsection{Representação do Ambiente}

O conhecimento que um robô móvel possui sobre seu ambiente pode ser representado por um modelo ou mapa, que o auxilia durante sua navegação pelo ambiente. Assim, um mapa é uma representação interna do ambiente no qual o robô está inserido. A escolha de uma representação do ambiente adequada pode ser determinante para o sucesso da realização de tarefas por robôs móveis. Segundo Siegwart e Nourbakhsh (2004), as seguintes questões devem ser consideradas para a escolha da representação do mapa: a acurácia do mapa deve corresponder à acurácia em que o robô deve atingir seus objetivos; a acurácia do mapa e o tipo de características representadas devem corresponder à acurácia e tipo de dado retornado pelos sensores do robô; e a complexidade da representação do mapa tem impacto direto na navegação. 
Um mapa pode ser construído considerando a representação espacial do ambiente, o que resulta em duas classes básicas de mapas: métrico e topológico.

Um mapa métrico é baseado em um sistema de coordenadas e na estimação numérica de onde os objetos estão no ambiente. A representação métrica pode ser dividida em grade de ocupação e mapas geométricos.

Na representação por grade de ocupação, o ambiente é dividido em uma grade, onde cada célula representa uma pequena área do ambiente e possui informação a respeito da ocupação ou não da célula. A grade de ocupação foi utilizada por Moravec e Elfes (1985) e Fox, Burgard e Thrun (1999) e pode ser vista na Figura 2.3(a). Na figura, o ambiente é dividido em uma grade com células do mesmo tamanho. As células não preenchidas representam espaço vazio e células pintadas representam espaço ocupado.

No mapa geométrico, os objetos ou obstáculos no ambiente são representados por primitivas geométricas como pontos, linhas, polígonos, etc. No trabalho de Leonard e Durrant-Whyte (1991), as primitivas geométricas utilizadas são planos, quinas, cantos e cilindros, parametrizadas pela sua posição no sistema de coordenadas do ambiente. A Figura 2.3(b) mostra um exemplo de um mapa geométrico, com dois planos, $p_{1}$ e $p_{2}$, um canto indicado por $p_{3}$ e um cilindro anotado por $p_{4}$.

Um mapa topológico representa informação de conectividade entre regiões ou objetos do ambiente. Em teoria, esta forma de representação não envolve nenhuma informação métrica. Esta representação é baseada em grafos, em que seus vértices representam lugares e são conectados por arestas que indicam os caminhos entre os lugares. O mapa topológico foi empregado por Ulrich e Nourbakhsh (2000). Um exemplo de mapa topológico é apresentado na Figura 2.3(c). Na figura está representado um local composto por 5 salas $\left(s_{1}, s_{2}, \ldots, s_{5}\right)$, com um grafo sobreposto. Cada vértice do grafo representa uma das salas e as arestas representam os caminhos entre as salas.

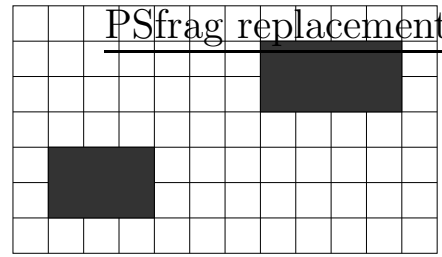

(a)

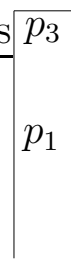

$p_{1}$

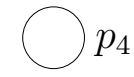

(b)

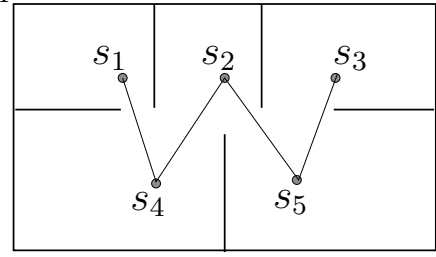

(c)

Figura 2.3: Representações do ambiente: (a) grade de ocupação, (b) mapa geométrico e (c) mapa topológico. 
Os mapas métricos possuem a vantagem de oferecerem valores acurados sobre a posição do robô, mas possuem a desvantagem de necessitarem de mais espaço para armazenamento de informações. Os mapas topológicos possuem a vantagem de serem mais compactos, mas no entanto, oferecem informação mais vaga sobre a posição do robô.

O mapa do ambiente pode ser fornecido a priori, mas, neste caso, o robô fica dependente de um humano para construí-lo. Uma solução para este problema é o robô construir seu próprio mapa, baseado na sua percepção do ambiente, enquanto explora as áreas desconhecidas. A tarefa de mapeamento ou construção de mapas refere-se à construção do mapa pelo próprio robô, baseada nas suas observações do ambiente. Exploração, para construção de mapas, significa a movimentação do robô pelo espaço livre do ambiente mapeando as áreas desconhecidas. Assume-se que o robô começa a exploração sem nenhum conhecimento do ambiente, e então, segue alguma estratégia de movimento que maximize a quantidade mapeada do ambiente no menor tempo ou distância percorrida possíveis.

\subsection{Técnicas de Localização}

Localização, ou auto-localização, de robôs móveis refere-se à capacidade do robô em responder a pergunta "onde estou?". Saber onde se encontra envolve estimar sua posição e orientação em relação a uma representação do ambiente. A informação de posição pode ser obtida tanto em termos qualitativos, por exemplo o robô está na sala 1, ou seja, em relação a um mapa topológico, quanto em termos quantitativos, como o robô está na postura $\left(5,4,30^{\circ}\right)$, ou seja, localizado em relação a um mapa métrico. É preciso distinguir entre dois termos empregados, por vezes indistintamente, na literatura de localização de robôs móveis: postura e posição. O termo postura, $(x, y, \theta)$, refere-se à posição $(x, y)$ e à orientação $\theta$ do robô em um sistema de coordenadas do ambiente.

Uma maneira do robô se localizar em um ambiente é através da integração do caminho percorrido, ou dead reckoning. Supondo que o robô conheça sua posição inicial, à medida que se movimenta no ambiente, sua posição é atualizada através das medidas dos sensores internos de movimento, por exemplo, informação de odometria. A localização baseada puramente em dead reckoning pode ser eficaz nos casos em que o robô percorre pequenas distâncias; no entanto, para distâncias maiores, o robô não consegue localizar-se de forma acurada, devido a erros do sensoriamento. 
A localização baseada puramente em marcos mostra-se uma alternativa ao dead reckoning. Marcos de referência são extraídos a partir da percepção do robô em relação ao ambiente, ou seja, através da leitura de seus sensores externos. Segundo Nehmzow (1999): "Marcos são percepções sensoriais dependentes da localização". Um problema que ocorre com a localização baseada puramente em marcos é que lugares distintos podem parecer similares, o que leva a erros de localização. Este problema é conhecido como percepção ambígua e ocorre em ambientes com a aparência homogênea, como escritórios e laboratórios.

A localização baseada em dead reckoning e a localização baseada em marcos diferem, entre outras coisas, no tipo de informação utilizada para estimar a posição do robô. A primeira utiliza informação interna, por exemplo, odometria, e a segunda utiliza percepção externa, ou seja, percepção do ambiente.

Buscando diminuir os erros encontrados em cada uma das estratégias de localização em separado, utiliza-se um sistema híbrido, combinando dead reckoning e percepção sensorial. Neste sistema, o erro de odometria é corrigido através da correspondência de marcos observados no ambiente com o mapa, e os eventuais casos de percepção ambígua são corrigidos através de dead reckoning. A localização híbrida é bastante utilizada, sendo, em geral, conhecida como localização baseada em marcos (NEHMZOW, 1999; THRUN, 1998; KRÖSE, 2001).

A localização de robôs móveis pode ser classificada considerando:

- o conhecimento sobre a postura inicial do robô:

- Em muitas aplicações, a estimação inicial da postura do robô é conhecida. Nestes casos, a tarefa de localização consiste em rastrear a posição do robô no tempo. Esta técnica é conhecida como localização incremental, localização local ou rastreamento de posição.

- No caso em que o robô não conhece sua posição inicial, o problema de localização consiste do robô encontrar sua posição em relação ao ambiente. Este problema é chamado de localização global ou absoluta. A localização global é necessária não só quando o robô desconhece sua posição inicial, mas também quando o robô perde seu conhecimento sobre sua posição, devido, por exemplo, aos erros de percepção. Neste caso, a localização global possibilita que o robô localize-se novamente no ambiente.

- os tipos de sensores utilizados: 
- Na localização utilizando sensores internos, o robô encontra sua posição no ambiente utilizando a percepção de seus movimentos obtida através do sensores internos, como os odômetros.

- Na localização utilizando sensores externos, o robô encontra sua posição no ambiente através das observações dos sensores externos, como sonar, câmera, etc.

- A localização utilizando sensores internos e externos utiliza informação dos dois tipos de sensores para localizar o robô. Este tipo de localização é o mais comum, uma vez que a maioria dos robôs é dotado de ambos os tipos de sensores que, juntos, fornecem mais e melhores informações sobre a localização do robô.

- a utilização ou não de uma representação do ambiente:

- Na localização sem mapa, o robô consegue encontrar sua posição sem utilizar uma representação do ambiente.

- Na localização com mapa, o robô localiza-se auxiliado pelas informações da sua representação do ambiente.

- a utilização de algoritmos:

- localização não probabilísticos, que não consideram os erros das medidas dos sensores e a incerteza na posição do robô.

- probabilísticos, que modelam os erros dos sensores e representam a incerteza sobre a posição do robô.

Os algoritmos de localização existentes são uma combinação das técnicas de localização descritas acima. Na localização puramente baseada em dead reckoning o robô conhece sua localização inicial no ambiente, e incrementa-a, utilizando as percepções de movimento fornecidas pelos odômetros, ou seja, é uma técnica de localização incremental, com sensores internos, sem mapa e não probabilística.

Outro exemplo de localização não probabilística é a triangulação, que utiliza o conhecimento sobre a geometria de objetos com suas posições conhecidas no ambiente para encontrar a posição do robô. A localização utilizando triangulação pode ser encontrada nos trabalhos de Livatino e Madsen (1999) e Thompson, Zelinsky e Srinivasan (1999). 


\subsection{Considerações Finais}

Neste capítulo foi apresentada uma breve introdução da área de robótica móvel, com ênfase na tarefa de localização. Técnicas probabilísticas de localização mostram-se mais adequadas uma vez que as informações obtidas através das leituras dos sensores são imprecisas. A localização probabilística, que modela o erro dos sensores e representa a incerteza sobre a localização do robô, é apresentada no próximo capítulo. 


\section{Técnicas Probabilísticas para Localização}

Um robô móvel localiza-se em relação a um ambiente conhecido utilizando sua percepção do ambiente e o conhecimento dos seus movimentos. Um robô percebe um ambiente através das medidas obtidas de seus sensores externos. As informações recebidas por sensores são não acuradas e ruidosas. No entanto, mesmo para um sensor livre de erros, a informação fornecida é limitada pelo fato dos sensores poderem medir apenas parte do ambiente. Por exemplo, para um sensor de distância, como um sonar, a região sensoriada é limitada pelo alcance e ângulo de abertura do sensor. Ainda, as informações obtidas pelos sensores podem ser ambíguas, sendo que existem vários locais do ambiente que fornecem o mesmo valor de medida do sensor. Considerando ainda o sonar, não é raro encontrar a mesma medida de distância de diferentes partes do ambiente.

O movimento do robô também pode não ser acurado, sendo que o resultado da execução de um comando para um robô se deslocar 1 metro pode ser um deslocamento, de fato, de alguns centímetros a mais ou a menos. Em geral, a informação sobre o deslocamento dos robôs é obtida pelos odômetros, que medem as rotações das rodas dos robôs. Esta informação pode apresentar erros devido a um deslizamento das rodas ou uma diferença de diâmetro entre as mesmas.

Robôs móveis se localizam em relação a um mapa do ambiente. O mapa é uma representação do ambiente, que é uma aproximação do ambiente real. Esta característica da representação do ambiente leva a mais uma fonte de incerteza para a tarefa de localização de robôs móveis.

Considerando que as informações sensoriais são ruidosas, não acuradas, além de limitadas, os robôs têm que lidar com diversos tipos de incertezas para poderem se localizar em um ambiente, sendo necessário fundir medidas incertas, de diferentes sensores, obtidas em posições e tempos distintos. Para atender estas necessidades, a localização probabilística modela os erros dos sensores e representa a incerteza sobre a postura do robô. A localização probabilística é bastante em- 
pregada na literatura, como nos trabalhos de Leonard e Durrant-Whyte (1991), Jensfelt (2001), Fox (1998), Thrun (1998), Kröse (2001), Thrun (2001) e Fox (1999).

O princípio básico de todos os algoritmos de localização probabilística é o filtro de Bayes. Pelo filtro de Bayes, busca-se estimar a postura do robô $\mathbf{x}_{t}$ baseada nas medidas dos sensores. Isto é feito intercalando medidas dos sensores internos com medidas dos sensores externos. O conjunto de medidas dos sensores é formado por observações dos sensores externos $\mathbf{o}_{1}, \ldots, \mathbf{o}_{t}$, como sonar, câmera, etc., e leituras dos sensores internos $\mathbf{a}_{1}, \ldots, \mathbf{a}_{t}$, como leituras do odômetros, obtidas durante um intervalo de tempo. Este conjunto de medidas constitui toda a informação disponível pelos sensores até o tempo t. Assim, a crença do robô estar na postura $\mathbf{x}_{t}$, dadas as leituras dos sensores $\mathbf{o}_{1}, \ldots, \mathbf{o}_{t}, \mathbf{a}_{1}, \ldots, \mathbf{a}_{t}$ é:

$$
p\left(\mathbf{x}_{t} \mid \mathbf{o}_{1}, \ldots, \mathbf{o}_{t}, \mathbf{a}_{1}, \ldots, \mathbf{a}_{t}\right)=\frac{p\left(\mathbf{o}_{1}, \ldots, \mathbf{o}_{t}, \mathbf{a}_{1}, \ldots, \mathbf{a}_{t} \mid \mathbf{x}_{t}\right) p\left(\mathbf{x}_{t}\right)}{p\left(\mathbf{o}_{1}, \ldots, \mathbf{o}_{t}, \mathbf{a}_{1}, \ldots, \mathbf{a}_{t}\right)}
$$

onde $p\left(\mathbf{o}_{1}, \ldots, \mathbf{o}_{t}, \mathbf{a}_{1}, \ldots, \mathbf{a}_{t} \mid \mathbf{x}_{t}\right)$ é a distribuição de probabilidade de obter as medidas dos sensores $\mathbf{o}_{1}, \ldots, \mathbf{o}_{t}, \mathbf{a}_{1}, \ldots, \mathbf{a}_{t}$, dada a postura $\mathbf{x}_{t}$, e $p\left(\mathbf{x}_{t}\right)$ é a distribuição de probabilidade a priori de $\mathbf{x}_{t}$.

As técnicas de localização probabilística necessitam de dois modelos probabilísticos, um modelo de movimento e um modelo de observação. O modelo de movimentodescreve o efeito de um comando de movimento sobre a postura do robô. Quando o robô executa um movimento, sua crença sobre sua postura deve ser atualizada. O modelo de movimento é dado por $p\left(\mathbf{x}_{t}=x \mid \mathbf{x}_{t-1}=x^{\prime}, \mathbf{a}_{t}\right)$, ou seja, a crença do robô estar na postura $x$, dado que sua postura anterior era $x^{\prime}$ e que tenha efetuado o movimento a. No entanto, o movimento não é acurado e aumenta a incerteza do robô. Para diminuir essa incerteza, o robô faz uma leitura do sensor externo e atualiza sua crença sobre sua postura de acordo com a informação fornecida por este sensor. Este modelo é chamado de modelo de observação e descreve a relação entre a leitura do sensor e a postura do robô. O modelo de observação é dado por $p\left(\mathbf{x}_{t}=x \mid \mathbf{o}_{t}\right)$, ou seja, a crença do robô estar na postura $x$, dado que observou $\mathbf{o}_{t}$.

As técnicas de localização probabilística diferem em como a incerteza sobre a postura do robô é representada. Nas seções seguintes são apresentadas algumas técnicas principais de localização probabilística de robôs, nomeadamente: filtro de Kalman, localização de Markov e filtro de partículas. Por fim, é apresentada uma discussão sobre estas diferentes técnicas. 


\subsection{Filtro de Kalman}

O Filtro de Kalman (FK) foi publicado pela primeira vez por Kalman (1960) como uma solução recursiva para o problema de filtragem linear de sistemas discretos. FK é um conjunto de equações matemáticas que possibilita estimar recursivamente o estado de um sistema linear, com variância mínima segundo um dado critério de otimalidade, por exemplo, o erro médio quadrado (MAYBECK, 1979; GELB, 1996). As informações de interesse no sistema podem ser representadas por um vetor de estado $\mathbf{x}(t), n$-dimensional, no tempo $t$. No caso da localização $\mathbf{x}(t)=(\mathbf{x}(t), \mathbf{y}(t), \theta(t))$. O filtro de Kalman, então, estima o estado do sistema utilizando os conhecimentos de:

- Modelo da dinâmica do sistema - no caso, representa o modelo do movimento do robô, medido pelos sensores internos.

- Modelo de observação - representa o modelo dos sensores externos do robô.

- Estatísticas dos ruídos da dinâmica e erros de observação - incerteza associada ao movimento e aos sensores externos de localização do robô.

- Informações das condições iniciais - localização inicial do robô.

Para iniciar o FK é necessário conhecer os valores estimados para a postura inicial $\mathbf{x}(0)$ e a matriz de covariância $\mathbf{P}(0 \mid 0)$. Assume-se que os erros do movimento do robô $\mathbf{w}(t)$ e da observação $\mathbf{v}(t)$ são seqüências brancas ${ }^{1}$ de média nula não correlacionados, ou seja, $E[\mathbf{w}(t)]=E[\mathbf{v}(t)]=0$ e $E\left[\mathbf{w}(t) \mathbf{v}^{T}(t)\right]=0$.

O FK opera em um ciclo de predição-emparelhamento-atualização, como mostra a Figura 3.1. Na fase de predição, a postura do robô e as observações são estimadas num tempo futuro utilizando o modelo de movimento do robô e o modelo de observação, respectivamente. Na fase de emparelhamento, as observações reais são correspondidas com as observações preditas, selecionando as observações válidas. Por fim, na atualização, a predição da postura é corrigida utilizando as observações válidas.

\section{Modelo de Movimento}

O modelo de movimento do robô descreve como a postura $\mathbf{x}(t)$ muda com o tempo na presença do ruído $\mathbf{w}(t)$, sendo descrito como:

$$
\mathbf{x}(t+1)=\mathbf{F}(t) \mathbf{x}(t)+\mathbf{w}(t),
$$

\footnotetext{
${ }^{1}$ seqüencias de erros não correlacionados no tempo.
} 


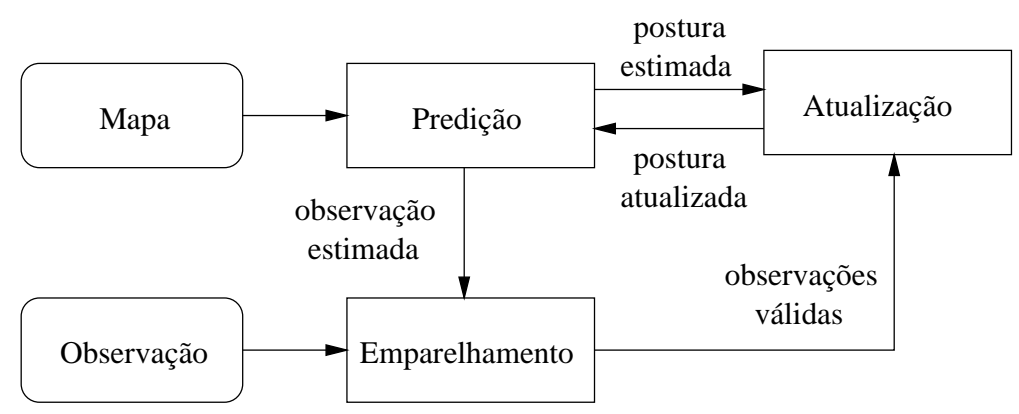

Figura 3.1: O filtro de Kalman para localização.

onde $\mathbf{w}(t)=N(0, \mathbf{Q}(t))$ é o vetor de erro branco da postura, que modela a incerteza nos elementos da postura. A função $\mathbf{F}(t)$ é uma função de transição de estado que projeta o estado real $\mathbf{x}(t)$ no tempo $t+1$. A função $\mathbf{F}(t)$ é linear e incorpora o comando de movimento do robô denotado por $\mathbf{u}(t)$.

\section{Modelo de Observação}

O modelo de observação relaciona as observações com a postura do robô, assumindo que as observações são corrompidas por ruído. O modelo é descrito por:

$$
\mathbf{z}(t)=\mathbf{H}(t) \mathbf{x}(t)+\mathbf{v}(t),
$$

onde $\mathbf{v}(t)=N(0, \mathbf{R}(t))$ é o vetor de erro branco de observações. A função de observação $\mathbf{H}(t)$ relaciona o vetor de postura $\mathbf{x}(t)$ com o vetor de observações $\mathbf{z}(t)$. A função $\mathbf{H}(t)$ é linear e utiliza o mapa do ambiente e a postura atual para calcular a observação $\mathbf{z}(t)$. A existência de uma função $\mathbf{H}(t)$ está condicionada à existência de um modelo de sensor que possa ser invertido.

\section{Predição}

A fase de predição estima a postura do robô no tempo $t+1$ dadas as observações e a estimação até o tempo $t$. A predição da postura é descrita por:

$$
\begin{aligned}
\overline{\mathbf{x}}(t+1 \mid t) & =\mathbf{F}(t) \overline{\mathbf{x}}(t \mid t), \\
\mathbf{P}(t+1 \mid t) & =\mathbf{F}(t) \mathbf{P}(t \mid t) \mathbf{F}^{T}(t)+\mathbf{Q}(t) .
\end{aligned}
$$

A matriz $\mathbf{P}(t+1 \mid t)$ é a matriz de covariância da postura, que representa a incerteza da estimação $\overline{\mathbf{x}}(t+1 \mid t)$.

A predição das observações é calculada usando a postura estimada $\overline{\mathbf{x}}(t+1 \mid t)$, considerando que a predição é a resposta ideal do sensor, livre de erros.

$$
\overline{\mathbf{z}}(t+1 \mid t)=\mathbf{H}(t) \overline{\mathbf{x}}(t+1 \mid t) .
$$




\section{Emparelhamento}

Na fase de emparelhamento, a observação real $\mathbf{z}(t+1)$ é comparada com a observação predita $\overline{\mathbf{z}}(t+1 \mid t)$. A diferença entre as observações é chamada inovação ou resíduo, dada por:

$$
\begin{aligned}
\mathbf{r}(t+1) & =\mathbf{z}(t+1)-\overline{\mathbf{z}}(t+1 \mid t) \\
\mathbf{S}(t+1) & =\mathbf{H}(t+1) \mathbf{P}(t+1 \mid t) \mathbf{H}^{T}(t+1)+\mathbf{R}(t+1)
\end{aligned}
$$

onde $\mathbf{S}(t+1)$ é a matriz de covariância da inovação. Para validar uma observação, utiliza-se: $\mathbf{r}(t+1) \mathbf{S}^{-1}(t+1) \mathbf{r}^{T}(t+1) \geq \alpha$, para um dado limiar $\alpha$. Quando há uma correspondência entre uma observação $\mathbf{z}(t+1)$ e uma predição $\overline{\mathbf{z}}(t+$ $1 \mid t)$, a observação $\mathbf{z}(t+1)$ é considerada uma observação válida. Apenas as observações válidas são utilizadas na fase de atualização. O emparelhamento é utilizado para ignorar observações ruidosas ou predições erradas, pois estas informações incorretas podem levar à divergência do filtro.

\section{Atualização}

A fase de atualização utiliza a inovação para corrigir a predição da postura $\overline{\mathbf{x}}(t+1 \mid t)$, computando a estimação da postura atualizada $\overline{\mathbf{x}}(t+1 \mid t+1)$, dada por:

$$
\begin{aligned}
\overline{\mathbf{x}}(t+1 \mid t+1) & =\overline{\mathbf{x}}(t+1 \mid t)+\mathbf{K}(t+1) \mathbf{r}(t+1) \\
\mathbf{P}(t+1 \mid t+1) & =\mathbf{P}(t+1 \mid t)-\mathbf{K}(t+1 \mid t) \mathbf{H}(t+1) \mathbf{P}(t+1), \\
\mathbf{K}(t+1) & =\mathbf{P}(t+1 \mid t) \mathbf{H}^{T}(t+1) \mathbf{S}^{-1}(t+1)
\end{aligned}
$$

A matriz $\mathbf{P}(t+1 \mid t+1)$ é a matriz de covariância do postura do robô e a matriz $\mathbf{K}(t+1)$ é o ganho de Kalman. O ganho é utilizado na atualização da predição da postura e no cálculo da matriz de covariância da postura, para ponderar a inovação entre as observações preditas e reais.

Um resumo das equações do FK discreto pode ser visto na Tabela 3.1, em que as equações são apresentadas pelas fases de predição, emparelhamento e filtragem.

O FK original assume que os modelos de movimento do robô e observação são lineares. No entanto, a maioria dos modelos de robôs móveis reais não são lineares e possuem erros não gaussianos. Se os erros forem aproximadamente gaussianos, o filtro de Kalman em sua versão estendida pode ser utilizado, embora, neste caso, não haja garantia de otimalidade do filtro. Modelos não lineares podem ser preditos utilizando o Filtro de Kalman Estendido (FKE). O FKE realiza uma linearização dos modelos não lineares, através da utilização do Jacobiano 
Tabela 3.1: Equações do Filtro de Kalman Discreto.

\begin{tabular}{|c|}
\hline Modelos \\
\hline Modelo de Movimento \\
$\mathbf{x}(t+1)=\mathbf{F}(t) \mathbf{x}(t)+\mathbf{w}(t), \mathbf{w}(t)=N(0, \mathbf{Q}(t))$ \\
Modelo de Observação \\
$\mathbf{z}(t)=\mathbf{H}(t) \mathbf{x}(t)+\mathbf{v}(t), \mathbf{v}(t)=N(0, \mathbf{R}(t))$ \\
\hline Predição \\
\hline Estimação da Postura \\
$\overline{\mathbf{x}}(t+1 \mid t)=\mathbf{F}(t) \overline{\mathbf{x}}(t \mid t)$ \\
Covariância da Postura \\
$\mathbf{P}(t+1 \mid t)=\mathbf{F}(t) \mathbf{P}(t \mid t) \mathbf{F}^{T}(t)+\mathbf{Q}(t)$ \\
Estimação das Observações \\
$\overline{\mathbf{z}}(t+1 \mid t)=\mathbf{H}(t) \overline{\mathbf{x}}(t+1 \mid t)$ \\
Emparelhamento \\
Inovação \\
$\mathbf{r}(t+1)=\mathbf{z}(t+1)-\overline{\mathbf{z}}(t+1 \mid t)$ \\
Covariância da Inovação \\
$\mathbf{H}(t+1) \mathbf{P}(t+1 \mid t) \mathbf{H}^{T}(t+1)+\mathbf{R}(t+1)$ \\
Atualização \\
$\mathbf{S}(t+1)=\mathbf{K a ́ l c u l o ~ d o ~ G a n h o ~ d e ~ K a l m a n ~}$ \\
\hline $\mathbf{P}(t+1 \mid t) \mathbf{H}^{T}(t+1) \mathbf{S}^{-1}(t+1)$ \\
Estimação do Estado \\
$\mathbf{K}(t+1)=\overline{\mathbf{x}}(t+1 \mid t)+\mathbf{K}(t+1) \mathbf{r}(t+1)$ \\
Covariância da Postura \\
$\mathbf{\mathbf { x }}(t+1 \mid t+1) \mathbf{P}(t+1) \mathbf{P}(t+1)$ \\
$\mathbf{P}(t+1 \mid t+1)=\mathbf{P}(t+1 \mid t)-\mathbf{K}(t+1 \mid t) \mathbf{H}(t+1)$
\end{tabular}


dos modelos.

Os modelos de movimento e da observação são dados por:

$$
\begin{aligned}
\mathbf{x}(t+1) & =\mathbf{f}(t) \mathbf{x}(t)+\mathbf{w}(t), \\
\mathbf{z}(t) & =\mathbf{h}(t) \mathbf{x}(t)+\mathbf{v}(t),
\end{aligned}
$$

onde $\mathbf{f}(t)$ é uma função não linear de transição de postura e $\mathbf{h}(t)$ é uma função não linear de observação.

\section{Predição}

Para predizer a postura $\overline{\mathbf{x}}(t+1 \mid t)$ utiliza-se uma linearização de $\mathbf{f}(t)$, dada por:

$$
\mathbf{F}(t)=\frac{\partial f(\overline{\mathbf{x}}(t \mid t))}{\partial \overline{\mathbf{x}}(t \mid t)},
$$

em que $\mathbf{F}(t)$ é calculada para $\mathbf{x}(t)=\overline{\mathbf{x}}(t \mid t)$. As predições da postura e da matriz de covariância são dadas por:

$$
\begin{aligned}
\overline{\mathbf{x}}(t+1 \mid t) & =\mathbf{f}(t) \overline{\mathbf{x}}(t \mid t), \\
\mathbf{P}(t+1 \mid t) & =\mathbf{F}(t) \mathbf{P}(t \mid t) \mathbf{F}^{T}(t)+\mathbf{Q}(t) .
\end{aligned}
$$

A predição das observações é calculada usando a postura estimada $\overline{\mathbf{x}}(t+1 \mid t)$,

$$
\overline{\mathbf{z}}(t+1 \mid t)=\mathbf{h}(t) \overline{\mathbf{x}}(t+1 \mid t) .
$$

\section{Emparelhamento}

A fase de emparelhamento utiliza as observações reais $\mathbf{z}(t+1)$ para comparar com as observações preditas $\overline{\mathbf{z}}(t+1 \mid t)$. A inovação é dada por:

$$
\begin{aligned}
\mathbf{r}(t+1) & =\mathbf{z}(t+1)-\overline{\mathbf{z}}(t+1 \mid t) \\
\mathbf{S}(t+1) & =\mathbf{H}(t+1) \mathbf{P}(t+1 \mid t) \mathbf{H}^{T}(t+1)+\mathbf{R}(t+1),
\end{aligned}
$$

onde $\mathbf{H}(t+1)$ é a linearização de $\mathbf{h}(t+1)$ em relação a $\overline{\mathbf{z}}(t+1 \mid t)$, ou seja,

$$
\mathbf{H}(t+1)=\frac{\partial h(\overline{\mathbf{x}}(t+1 \mid t))}{\partial \overline{\mathbf{x}}(t+1 \mid t)},
$$

em que $\mathbf{H}(t+1)$ é calculada para $\mathbf{x}(t+1)=\overline{\mathbf{x}}(t+1 \mid t)$. 
Tabela 3.2: Equações do Filtro de Kalman Estendido.

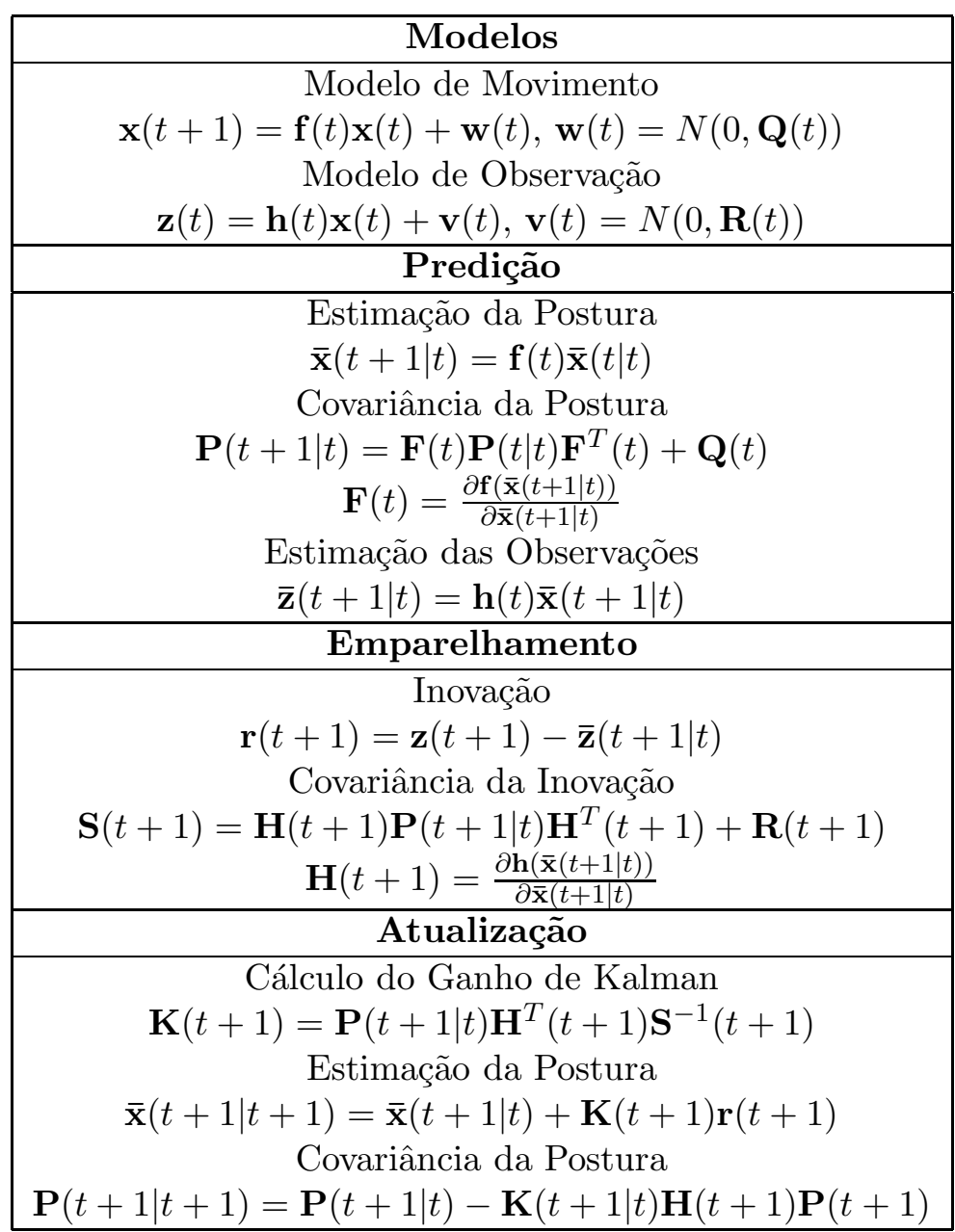




\section{Atualização}

A atualização da postura utilizando as observações válidas é dada por:

$$
\begin{aligned}
\overline{\mathbf{x}}(t+1 \mid t+1) & =\overline{\mathbf{x}}(t+1 \mid t)+\mathbf{K}(t+1) \mathbf{r}(t+1), \\
\mathbf{P}(t+1 \mid t+1) & =\mathbf{P}(t+1 \mid t)-\mathbf{K}(t+1 \mid t) \mathbf{H}(t+1) \mathbf{P}(t+1), \\
\mathbf{K}(t+1) & =\mathbf{P}(t+1 \mid t) \mathbf{H}^{T}(t+1) \mathbf{S}^{-1}(t+1)
\end{aligned}
$$

O algoritmo do FKE é muito similar ao FK linear, com as substituições de $\mathbf{f}(t)$ por $\mathbf{F}(t)$, e $\mathbf{h}(t+1)$ por $\mathbf{H}(t+1)$. As equações do FKE podem ser vistas na Tabela 3.2.

O FKE é bastante utilizado para localização de robôs móveis. No trabalho de Leonard e Durrant-Whyte (1991), o FKE é utilizado para solucionar o problema de localização em um ambiente conhecido, em que o marcos são descritos em termos da geometria do ambiente, ou seja, distâncias até as paredes. O sensor empregado para observar o ambiente é um sonar. No trabalho de Crowley (1995) o FKE é apresentado como uma maneira de corrigir os erros de estimação de postura por odometria através da integração das percepções externas, em que são utilizadas medidas de ângulo e distância de um marco, apenas ângulo ou apenas distância. Roumeliotis e Bekey (1997) também utilizam o FKE para localização de robôs móveis como uma forma de melhorar a localização por dead reckoning.

\subsection{Localização de Markov}

Localização de Markov (LM) é uma técnica probabilística que mantém uma distribuição de probabilidade sobre o espaço de todas as hipóteses de onde o robô pode estar ao invés de manter uma única hipótese sobre sua postura. Seja $\mathbf{x}_{t}$ a variável aleatória correspondente à postura do robô no ambiente no tempo $t$. Como o robô não conhece sua postura exata, ele possui apenas uma crença de onde ele poderia estar, denotada por $p\left(\mathbf{x}_{t}\right)^{2}$, ou seja, a distribuição de probabilidade sobre o espaço de posturas. Seja $x=(\mathrm{x}, \mathrm{y}, \theta)$ a postura do robô, dada pela posição $(\mathrm{x}, \mathrm{y})$ e orientação $\theta$, então $p\left(\mathbf{x}_{t}=x\right)$ é a crença que o robô atribui para a possibilidade de estar na postura $x$ no tempo $t$.

A LM recebe esse nome pois segue a suposição de Markov, em que a postura do robô depende apenas da postura anterior e das observações atuais, e sendo independente das observações passadas.

\footnotetext{
${ }^{2}$ Para simplificação de notação assume-se que $\mathbf{x}(t)=\mathbf{x}_{t}$.
} 
A LM necessita de dois modelos probabilísticos para manter a estimação da postura: o modelo de movimento e o modelo de observação. O espaço de posturas é denotado pelas posturas $\left\{\mathbf{x}_{t}^{1}, \mathbf{x}_{t}^{2}, \cdots, \mathbf{x}_{t}^{N}\right\}$, onde $N$ é o tamanho do espaço de posturas e o conjunto de leituras dos sensores até o tempo $t$ é dado por $d_{t}=\left\{\mathbf{o}_{0}, \ldots, \mathbf{o}_{t}, \mathbf{a}_{1}, \ldots, \mathbf{a}_{t-1}\right\}$.

O modelo de movimento estima a postura atual do robô, $\mathbf{x}_{t}=x$, dadas a leitura dos sensores internos $\mathbf{a}_{t}$ e a postura anterior, $\mathbf{x}_{t-1}=x^{\prime}$ :

$$
p\left(\mathbf{x}_{t}=x \mid \mathbf{a}_{t}\right)=\sum_{x^{\prime}} p\left(\mathbf{x}_{t}=x \mid \mathbf{x}_{t-1}=x^{\prime}, \mathbf{a}_{t}\right) p\left(\mathbf{x}_{t-1}=x^{\prime} \mid d_{t-1}\right),
$$

onde $p\left(\mathbf{x}_{t}=x \mid \mathbf{a}_{t}\right)$ é crença da postura antes de incorporar as leituras dos sensores externos, ou seja, a distribuição de probabilidade a priori.

O modelo de observação descreve a relação entre a observação o o $_{t}$ e a postura $\mathbf{x}_{t}$, dada por:

$$
p\left(\mathbf{x}_{t}=x \mid \mathbf{o}_{t}\right)=\frac{p\left(\mathbf{o}_{t} \mid \mathbf{x}_{t}=x\right) p\left(\mathbf{x}_{t-1}=x \mid d_{t-1}\right)}{\sum_{x^{\prime}} p\left(\mathbf{o}_{t} \mid \mathbf{x}_{t}=x^{\prime}\right) p\left(\mathbf{x}_{t-1}=x^{\prime} \mid d_{t-1}\right)},
$$

onde $p\left(\mathbf{x}_{t}=x \mid \mathbf{o}_{t}\right)$ é crença da postura após incorporar as leituras dos sensores externos, ou seja, a distribuição de probabilidade a posteriori.

A probabilidade $p\left(\mathbf{x}_{t}=x_{0}\right)$ representa o conhecimento inicial sobre a postura do robô. Se a postura inicial é conhecida aproximadamente, então $p\left(\mathbf{x}_{t}=x_{0}\right)$ é uma distribuição gaussiana estreita centrada na postura do robô. Se a postura inicial do robô não é conhecida, $p\left(\mathbf{x}_{t}=x_{0}\right)$ é uniformemente distribuída no espaço de posturas.

\section{Observação Negativa}

A grande maioria dos trabalhos que utilizam localização de Markov contam com um modelo de observação positiva, ou seja, estão baseados na identificação de características discriminantes do ambiente, ou marcos, pelos sensores. No entanto, o modelo de observação pode também ser construído para observações negativas, ou seja, quando a leitura do sensor não retorna o marco esperado.

Uma medida de informação negativa significa que, em um dado instante de tempo, espera-se que o sensor retorne uma leitura, que de fato não ocorre. A maioria das técnicas de estimação de estado usa um modelo do sensor que atualiza a crença do estado quando o sensor retorna uma medida. No entanto é possível ganhar informações úteis na ausência da medida do sensor.

A informação negativa foi utilizada para rastreamento de alvo usando o evento 
de não detectar um alvo como uma evidência para atualizar a função distribuição de probabilidade (KOCH, 2004). A informação negativa significa que o alvo não está localizado na área de visibilidade do sensor, e uma vez que se sabe que o alvo existe, ele está com certeza fora da área de visibilidade do sensor.

Na localização de robôs, a informação negativa, ou seja, a ausência de medidas de marcos, foi incorporada na localização de Markov por Hoffmann (2005). Oclusões são identificadas usando um sensor visual que rastreia cores do chão para determinar se há ou não obstáculos. O ambiente é um campo de futebol verde com linhas brancas, assim, qualquer cor diferente na imagem é considerada como sendo um obstáculo.

O modelo de observação negativa, proposto segundo Hoffmann (2005), descreve a relação entre a observação $\mathbf{o}_{t}^{-}$e a postura $\mathbf{x}_{t}$, dada por:

$$
p\left(\mathbf{x}_{t}=x \mid \mathbf{o}_{t}^{-}\right)=\frac{p\left(\mathbf{o}_{t}^{-} \mid \mathbf{x}_{t}=x, \mathbf{v}, \mathbf{o b s}\right) p\left(\mathbf{x}_{t-1}=x \mid d_{t-1}\right)}{\sum_{x^{\prime}} p\left(\mathbf{o}_{t}^{-} \mid \mathbf{x}_{t}=x^{\prime}\right) p\left(\mathbf{x}_{t-1}=x^{\prime} \mid d_{t-1}\right)}
$$

onde $p\left(\mathbf{x}_{t}=x \mid \mathbf{o}_{t}^{-}\right)$é crença da postura após incorporar a observação negativa $\mathbf{o}_{t}^{-}$. As variáveis $\mathbf{v}$ e obs representam a área de visibilidade do robô e os obstáculos identificados, respecti vamente.

A localização de Markov é utilizada por Fox, Burgard e Thrun (1999), Fox (1998) e Kröse e Bunschoten (1999) com um mapa de grade de ocupação. A distribuição de probabilidade da postura é mantida no espaço de posturas, que é do mesmo tamanho que a grade de ocupação, ou seja, para cada célula da grade é mantida uma probabilidade da postura do robô encontrar-se nesta célula. A LM pode também ser utilizada com um mapa topológico, como no trabalho de Simmons e Koenig (1995). No âmbito do futebol de robôs, a localização de Markov foi empregada por Penedo (2003) em que o campo de futebol foi discretizado em um mapa de grades.

O algoritmo para LM pode ser visto no Algoritmo 1, conforme apresentado por Fox, Burgard e Thrun (1999) e acrescido do modelo de observação negativa de Hoffmann (2005). A atualização da crença de postura do robô utilizando observação do ambiente, seja esta positiva ou negativa, deve ocorrer com o robô parado. As crenças de postura do robô são calculadas intercalando informação do ambiente com informação do movimento do robô. No caso do robô possuir, no mesmo instante de tempo, observação positiva e negativa a respeito de marcos distintos no ambiente, a atualização prefere a observação positiva, pois na maioria das vezes é mais informativa do que a observação negativa. 


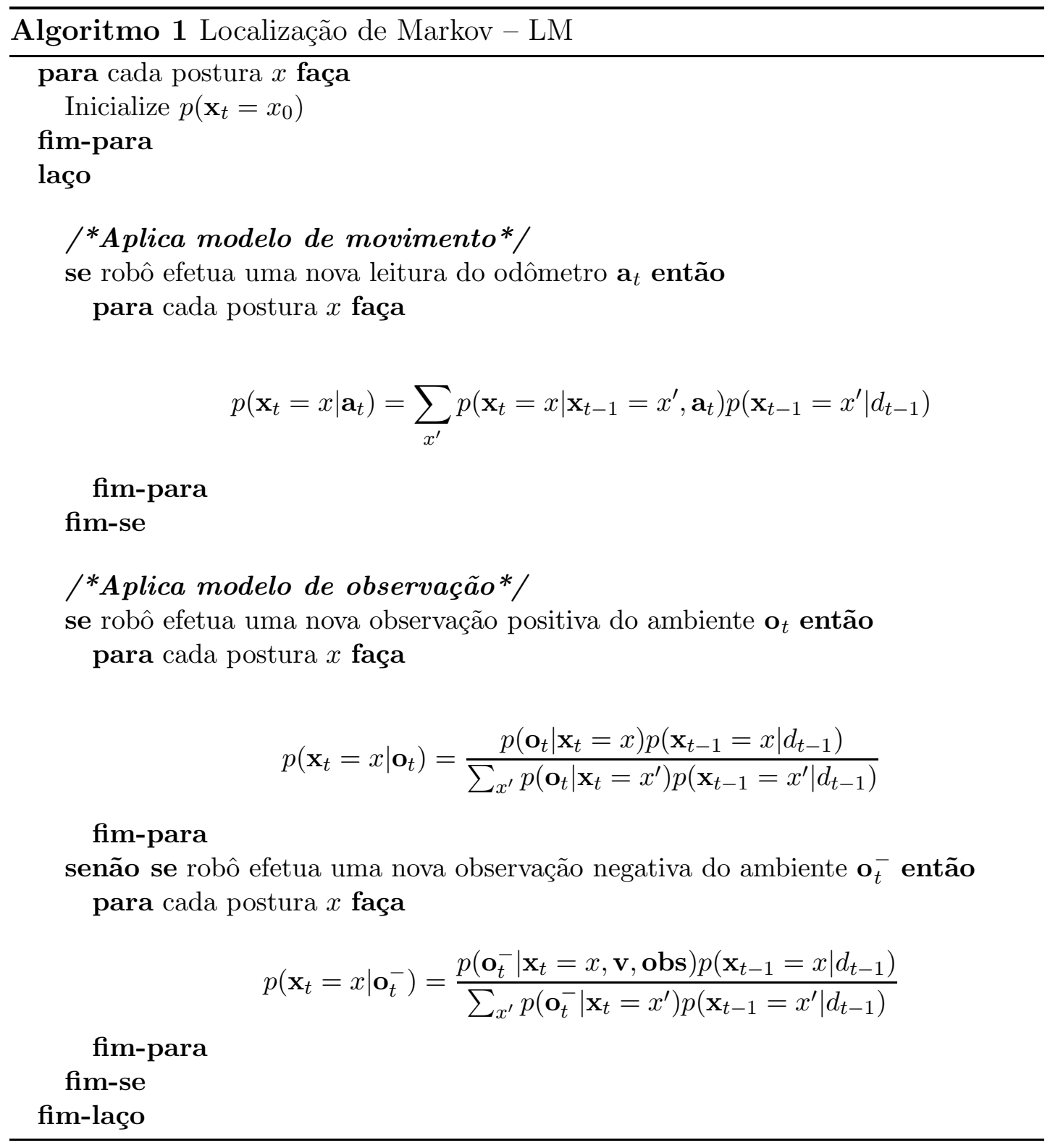




\subsection{Filtro de Partículas}

O Filtro de Partículas (FP), também conhecido como Localização Monte Carlo (LMC), representa a distribuição de probabilidade da postura $\mathbf{x}$ por um conjunto de $N$ amostras aleatórias, ou partículas. Um conjunto de partículas constitui uma aproximação discreta de uma distribuição de probabilidade. Partículas são pares ordenados, incluindo postura e peso, $\left(\mathbf{x}^{i}, \pi^{i}\right)$, para $i=1, \cdots, N$, onde $\mathbf{x}=(\mathrm{x}, \mathrm{y}, \theta)$ e $\pi \geq 0$ é o fator de importância, análogo a uma distribuição de probabilidade discreta com $\sum_{i=1}^{N} \pi^{i}=1$. O conjunto de partículas é denotado por $X=\left\{\left(\mathbf{x}^{1}, \pi^{1}\right),\left(\mathbf{x}^{2}, \pi^{2}\right), \cdots,\left(\mathbf{x}^{N}, \pi^{N}\right)\right\}$.

A função de distribuição de probabilidade inicial da postura do robô representa o conhecimento inicial sobre sua postura. No caso do robô não conhecer sua postura inicial, a distribuição de probabilidade é inicializada com uma distribuição uniforme sobre todas as posturas possíveis. O conjunto de partículas é inicializado escolhendo $N$ partículas distribuídas uniformemente no ambiente e atribuindo pesos também distribuídos uniformemente, ou seja $\pi_{0}^{i}=1 / N$ para $i=1, \cdots, N$.

Quando o robô executa um comando de movimento a, o FP gera $N$ novas partículas que aproximam a postura do robô após o movimento a, sendo este conjunto denotado por $\bar{X}$. Cada nova partícula $\left(\mathrm{x}^{i}, \pi^{i}\right)$, para $i=1, \cdots, N$, é dada por:

$$
\mathbf{x}^{i} \sim p\left(\mathbf{x}^{i} \mid \mathbf{x}^{i}, \mathbf{a}\right)
$$

Quando o robô realiza uma observação o do ambiente, esta observação é incorporada pelo FP, atualizando o valor do fator de importância de forma que:

$$
\pi_{t}^{i}=p\left(\mathbf{o} \mid \mathbf{x}^{i}\right)
$$

Este ajuste atribui pesos maiores para as partículas que correspondem às posturas onde o é mais provável de ser observado.

A fase seguinte é de reamostragem ou amostragem por importância, que transforma o conjunto de partículas $\bar{X}$ em um novo conjunto do mesmo tamanho $X$, em que as novas partículas são ponderadas pelos seus fatores de importância. Por incorporar os pesos das partículas, a distribuição das partículas muda, concentrando-se nas regiões em que há maior peso.

O algoritmo de localização utilizando FP, conforme descrito por Thrun, Bur- 
gard e Fox (2005), é apresentado no Algoritmo 2. Maiores detalhes sobre o filtro de partículas podem ser encontrados em (SMITH; GELFAND, 1992; ARULAMPALAM, 2002; THRUN, 2002).

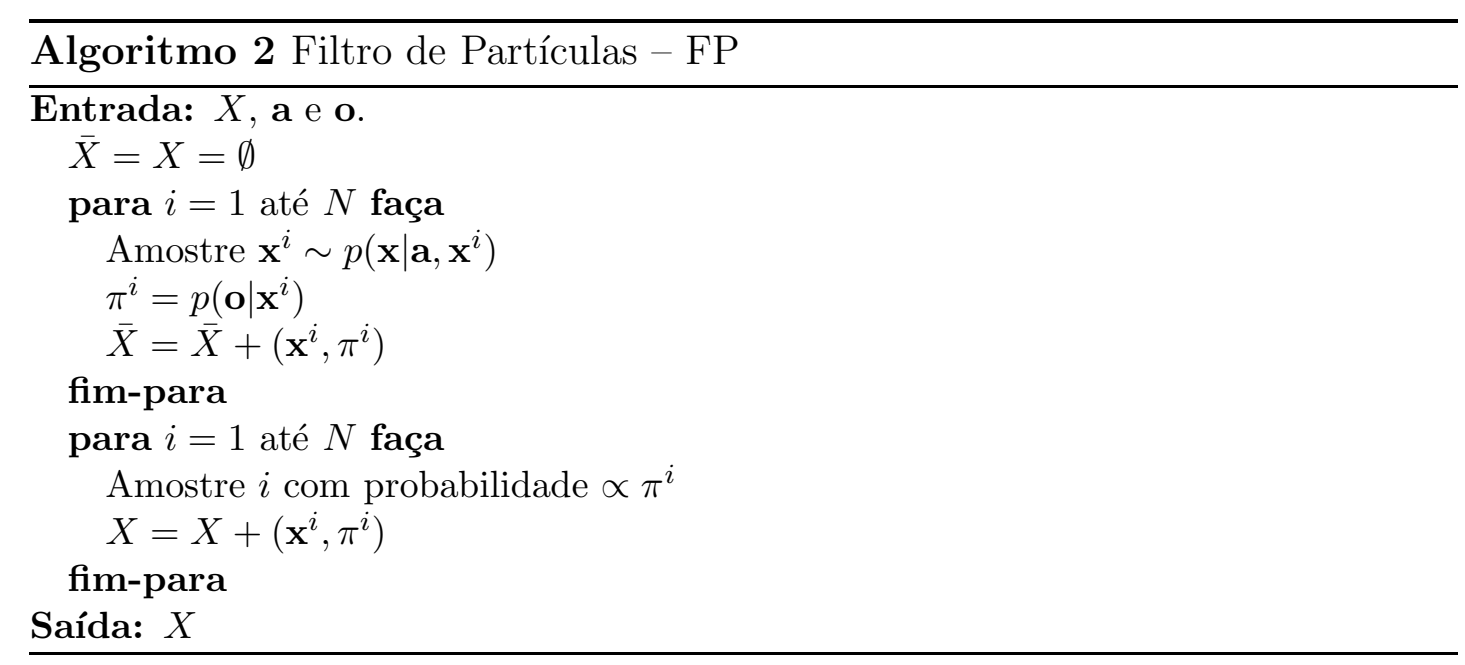

Uma melhora na eficiência do FP foi apresentada por Fox (2002) através de um filtro de partículas adaptativo com o tamanho do conjunto de partículas variável. Manter um conjunto fixo de partículas durante todo o processo de estimação pode ser bastante ineficiente, uma solução é manter um conjunto de partículas menor quando a densidade está concentrada em uma pequena parte do espaço de estados e, um conjunto maior de partículas quando a incerteza na crença de postura é grande.

Na localização utilizando FP, um conjunto de partículas, menor que a discretização do ambiente, é utilizado para manter a crença sobre a postura do robô apenas onde é necessário, ou seja, nas posturas que possuem partículas com peso maior. A localização de Markov com grade de ocupação, empregada por Thrun (2001) e Fox (1999), pode ser vista como um método baseado em partículas, em que cada partícula corresponde a uma célula da grade. A vantagem do FP em relação à LM é a redução na computação e memória necessárias.

O algoritmo de FP é bastante utilizado para localização de robôs móveis, como em (THRUN, 2001) e (REKLEITIS, 2004). No primeiro deles foi feita uma comparação entre diversos tamanhos de conjuntos de partículas e obteve-se bons resultados a partir de 1000 partículas. No segundo é apresentado um tutorial sobre localização de robôs móveis utilizando FP. Gross (2002) empregam o filtro de partículas para localizar um robô móvel que utiliza imagens omnidirecionais e um mapa híbrido, representado através de um grafo, em que seus nós correspondem a regiões do ambiente (informação topológica) e são rotulados com imagens do local e informação odométrica (informação métrica). 


\subsection{Modelo de Arquitetura para Localização de um Robô}

A estimação da postura de robôs móveis em um determinado ambiente é realizada através das percepções do robô sobre o ambiente e sobre seus próprios movimentos, sendo estas informações utilizadas para atualizar a crença de postura do robô. Considerando que as informações pertinentes para estimativa da postura são observações do ambiente e dos movimentos do robô, é possível identificar dois modelos: modelo de observação, que se refere à observação do robô sobre o ambiente e modelo de movimento, que se relaciona ao conhecimento do robô sobre os efeitos dos seus próprios movimentos.

A Figura 3.2 ilustra a relação entre esses modelos e a estimativa de postura, que é o objetivo da tarefa de localização. Uma breve descrição de cada item da arquitetura é dada a seguir:

Observação externa: é a percepção do robô sobre o ambiente obtida da leitura de sensores externos. Esta informação pode ser marcos visuais, como objetos discriminantes do ambiente, adquiridos de imagens obtidas de uma câmera, ou ainda, pode ser medidas das distâncias do robô às paredes, fornecidas por um sonar ou laser. As observações externas alimentam o modelo de observação.

Observação interna: é a observação dos movimentos do robô fornecida pela leitura de sensores internos. Para um robô móvel com rodas e direção diferencial, os movimentos podem ser leituras dos odômetros nas rodas direita e esquerda. As observações internas são entrada para o modelo de movimento.

Mapa: é uma representação do ambiente. Dependendo da aplicação um mapa pode ou não estar disponível. Para robôs que atuam em ambientes internos e bem estruturados como escritórios, hospitais, é possível fornecer uma planta do ambiente para ajudar na tarefa de localização. No entanto, para robôs de busca e salvamento, em uma área desconhecida ou destruída, um mapa pode não estar disponível ou estar desatualizado, não representando a atual configuração do ambiente.

Atualizar: é responsável pela atualização da estimativa da postura utilizando as informações recebidas pelos modelos de movimento e observação. A atualização utiliza um algoritmo de localização, como Filtro de Kalman ou 
localização de Markov.

Estimativa de postura: é a crença de postura do robô em um determinado instante. Representa o estado estimado, que pode ser a postura do robô, dada por $(\mathrm{x}, \mathrm{y}, \theta)$.

MO: é o modelo de observação, que recebe observações externas e informações sobre o mapa do ambiente e utiliza essas informações para relacionar a observação recebida com a postura do robô.

MM: é o modelo de movimento, que recebe observações internas e utiliza o conhecimento sobre como o robô se movimenta para descrever o efeito do movimento executado sobre a postura do robô.

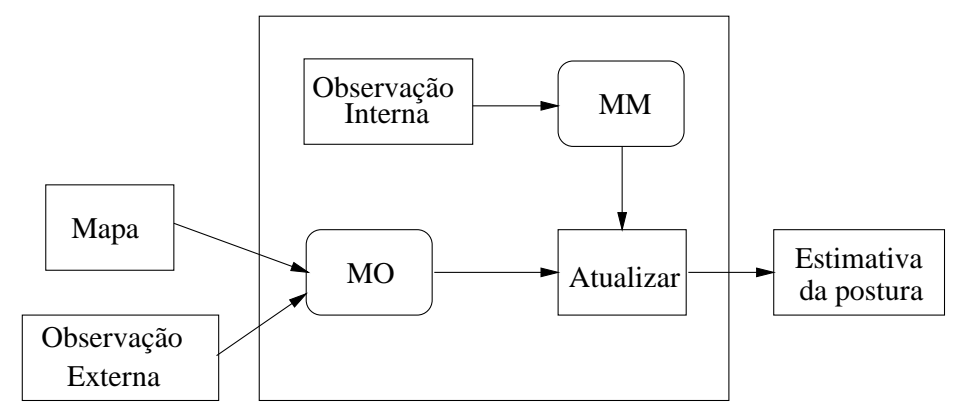

Figura 3.2: Modelo de arquitetura para localização de um robô móvel.

O modelo de observação pode tratar tanto de informações positivas como de negativas. A informação positiva está relacionada com a observação em que o robô percebeu no ambiente algum marco conhecido e esperado. A observação negativa ocorre quando a observação esperada não ocorre. A observação negativa é útil para a tarefa de localização uma vez que o robô pode diminuir sua crença de estar em uma determinada postura, caso ele não identifique os marcos esperados. A maior parte dos trabalhos de localização utiliza apenas o modelo de observação positiva, sendo o modelo de observação negativa relatado em (HOFFMANN, 2005).

Na localização baseada em mapa, o robô tenta se localizar coletando informações dos sensores e atualizando a crença de sua postura em relação ao mapa. A acurácia esperada na estimativa da postura do robô deve corresponder à acurácia da representação dos objetos no mapa.

A representação do mapa pode ser métrica, topológica ou híbrida. A escolha de quais marcos irão compor o mapa também depende de qual sensor é utilizado no robô. Por exemplo, para uma câmera pode-se ter como marcos objetos coloridos, ou de determinada forma e tamanho. No entanto para um sonar que mede 
distâncias, os marcos podem ser um conjunto de segmentos de reta que representam as distâncias aos obstáculos no ambiente, como por exemplo, a distância até as paredes.

Um robô pode representar a crença na sua postura em relação ao mapa como uma única postura atual ou como um conjunto de posturas possíveis. A representação de hipótese única é a mais direta, em que a crença do robô sobre sua postura é expressa por um único ponto no mapa.

Na representação de múltiplas hipóteses a crença do robô sobre sua postura é um conjunto de posturas. Esta representação permite que o robô mantenha incerteza sobre sua postura, podendo rastrear várias posturas possíveis. Nesta representação pode-se incluir a informação de quais posturas são mais prováveis que outras. Uma maneira de representar uma crença de múltiplas hipóteses é modelar a crença como uma distribuição matemática. Uma distribuição bastante utilizada é a gaussiana. A idéia é que a distribuição em cada postura representa a probabilidade do robô estar posicionado naquela postura. A distribuição gaussiana permite apenas uma única postura mais provável. Se for preciso lidar com ambiguidade é necessário utilizar outras distribuições, como uma multimodal.

Na localização sem mapa o robô tenta se localizar integrando sua crença de postura anterior com as percepções dos movimentos realizados, que são obtidas pela leitura dos sensores internos. A localização por dead reckoning é bastante errônea, com o erro de localização crescente em relação ao tempo de realização dos movimentos.

\subsection{Considerações Finais}

Esta seção apresenta uma comparação entre os métodos de localização probabilística. A análise comparativa a seguir está fundamentada nas comparações experimentais realizadas por Gutmann e Fox (2002), Kristensen e Jensfelt (2003) e Choset (2004).

A Tabela 3.3 mostra um comparação entre os algoritmos de localização de robôs móveis apresentados neste capítulo. Os itens comparados são linearidade dos modelos de observação e movimento, tipo da distribuição, representação da crença, tipo de localização e adaptabilidade.

A técnica de FK necessita que os modelos de movimento e observação sejam lineares. O FKE aceita os modelos não lineares, sendo estes linearizados. As técnicas de LM e FP lidam com modelos não lineares. 
Tabela 3.3: Comparação de algoritmos para localização de robôs.

\begin{tabular}{|c||c|c|c|c|c|}
\hline \hline Técnica & $\begin{array}{c}\text { Modelos } \\
\text { Não Lineares }\end{array}$ & $\begin{array}{c}\text { Tipo da } \\
\text { Distribuição }\end{array}$ & $\begin{array}{c}\text { Representação } \\
\text { da Crença }\end{array}$ & $\begin{array}{c}\text { Tipo de } \\
\text { Localização }\end{array}$ & Adaptativa \\
\hline \hline FK & não & unimodal & $(\mu, \Sigma)$ & Local & não \\
\hline FKE & $\operatorname{sim}$ & unimodal & $(\mu, \Sigma)$ & Local & não \\
\hline LM & $\operatorname{sim}$ & multimodal & regiões & Global & não \\
\hline FP & $\operatorname{sim}$ & multimodal & partículas & Global & sim \\
\hline \hline
\end{tabular}

As localizações utilizando o FK e o FKE representam apenas uma hipótese sobre a postura do robô, sendo incapazes de localização global ou recuperação de falhas totais de localização. No entanto, possuem a vantagem de serem eficientes e bastante acuradas. Um trabalho recente de Jensfelt (2001) introduz uma técnica de mistura de gaussianas que mantém um FKE para cada hipótese de postura, permitindo a localização global do robô e recuperação de falhas.

A LM utilizando grades de ocupação representa uma hipótese sobre a postura do robô para cada célula da grade, sendo capaz de localização global e recuperação de falhas. Um problema com esta técnica é a dimensão da grade de ocupação, que exige alguma técnica de otimização para aplicações reais.

A localização utilizando FP representa várias hipóteses sobre a postura do robô, sendo capaz de localização global. O algoritmo apresenta-se ineficiente para recuperar-se de falhas de localização, como no problema do seqüestro do robô, em que o robô é transportado para outra parte do ambiente, sem ser informado. Isso ocorre quando, na distribuição de partículas, não há partículas na nova região onde o robô está localizado, sendo assim impossível que o robô encontre sua postura. Uma solução para este problema é permitir inserir aleatoriamente partículas no conjunto de partículas.

Em relação à representação da crença, o FK e o FKE utilizam uma representação paramétrica que armazena a média e a covariância da distribuição gaussiana. As técnicas de LM e FP são não paramétricas e representam a distribuição de probabilidade como um conjunto de regiões ou um conjunto de partículas, respectivamente.

O fato da distribuição ser unimodal faz com que o FK e o FKE possam apenas realizar localização local, mas também faz com que o tempo de computação seja polinomial na dimensionalidade do espaço de estados. A LM e a localização com FP são ambas multimodais, o que permite que realizem localização global. Se o tamanho do conjunto de partículas for igual à discretização do ambiente, LM 
e FP têm o mesmo custo computacional. A vantagem do FP sobre a LM em relação ao tempo computacional ocorre se o conjunto de partículas for menor que a discretização do ambiente.

A técnica de FP pode ser implementada de forma adaptativa em relação aos recursos computacionais, ou seja, adapta o tamanho do conjunto de partículas em tempo real baseado nos recursos computacionais disponíveis. 


\section{Localização para Multirrobôs Cooperativos}

Existem muitas técnicas de localização para um robô. No caso de um grupo de robôs operando em um mesmo ambiente, o problema de localização pode ser solucionado independentemente para cada robô, em que cada um deles aplica uma técnica de auto-localização, utilizando sua experiência individual. Esta maneira de realizar localização de um grupo de robôs é simples e evita o problema de fundir informações entre os robôs do grupo. No entanto, na localização para multirrobôs cooperativos, cada robô estima sua postura, utilizando suas observações locais e as informações comunicadas pelos outros robôs. Esta abordagem possui a vantagem de compartilhar informações entre os robôs, contribuindo para melhorar a estimativa das posturas. Cada robô realiza observação de parte do ambiente, e como os robôs ocupam lugares distintos no ambiente, suas observações podem ser fundidas resultando em uma percepção aumentada do mesmo. Ainda, para o caso de robôs heterogêneos, que possuem sensores distintos, os robôs podem compartilhar observações que não obteriam isoladamente.

A localização de multirrobôs é abordada considerando um grupo de robôs móveis em que cada robô está equipado com:

- Sensores internos que medem o movimento do robô.

- Sensores externos que observam o ambiente e os outros robôs.

- Dispositivo de comunicação que permite que um robô troque informações com os outros robôs do grupo.

A estimação das posturas do grupo de robôs é calculada utilizando a informação de movimento de cada robô fornecida pelos sensores internos, informações do ambiente observadas por sensores externos de cada robô, e a informação de postura comunicada entre os robôs do grupo.

Desta maneira, a solução do problema de localização de multirrobôs necessita 
efetuar a fusão de informações dos diferentes sensores de cada robô, além da fusão de informações comunicadas pelos robôs do grupo. O problema de fusão de informações, ou fusão sensorial, é o processo de combinação de informações de vários sensores de forma a obter uma observação melhorada do ambiente (CROWLEY; DEMAZEAU, 1993).

Na Seção 4.1 são descritos alguns critérios de classificação para os métodos de localização cooperativa. Em seguida, na Seção 4.2, são relatados os trabalhos relacionados, seguindo-se de uma discussão sobre os mesmos na Seção 4.3. A cooperação entre os robôs é alcançada na maioria dos casos através de detecções, sendo o modelo de detecção apresentado na Seção 4.4. A localização multirrobôs utilizando o modelo de detecção é baseada na representação fatorada, e sua importância e limitações estão descritas na Seção 4.6. Por fim, algumas últimas considerações são feitas.

\subsection{Taxonomia}

Uma decisão importante na estimação da localização para um grupo de robôs é o tipo de arquitetura empregada para fundir as observações obtidas pelos mesmos. As arquiteturas podem ser classificadas, segundo Mutambara (1998), em centralizada, distribuída e descentralizada:

A arquitetura centralizada possui um robô líder que recebe as observações realizadas por todos os robôs do grupo, processa todas as observações obtidas e então devolve as informações processadas para o grupo. A fusão de informações realizada pelo robô líder utiliza todas as informações disponíveis no grupo, permitindo um tratamento adequado das informações. Uma desvantagem desta arquitetura é que uma falha do robô líder leva a falha de todo o grupo de robôs.

$\mathrm{Na}$ arquitetura distribuídao processamento das observações é distribuído entre os robôs, resultando em um processamento paralelo. As informações locais computadas pelos robôs precisam ser integradas por um robô líder. Esta arquitetura reduz o tempo computacional, uma vez que o processamento é dividido entre os robôs. Diferentemente da arquitetura centralizada, esta arquitetura não concentra todo o processamento em um único robô, mas ainda é sensível a uma falha do robô líder, que efetua a integração.

$\mathrm{Na}$ arquitetura descentralizadacada robô realiza o processamento de suas observações, não havendo um robô líder. A fusão de informações entre os 
robôs ocorre localmente em cada robô e consiste das observações locais do robô e as informações comunicadas pelos outros robôs do grupo.

Os vários métodos para localização cooperativa de multirrobôs podem ser classificados segundo alguns critérios. Além dos critérios já utilizados para um robô, como localização local ou global, o algoritmo de localização utilizado e o conhecimento ou não do mapa do ambiente, é possível identificar outros critérios pertinentes a um grupo de robôs como: tipo de arquitetura para estimação das posturas, tipo de informação de postura armazenada pelos robôs, tipo de movimento do grupo e tipo de robôs do grupo.

Em relação à informação de postura armazenada pelos robôs, esta pode ser de dois tipos: absoluta ou relativa. A informação de postura absolutaé a postura do robô em relação ao ambiente, ou seja, em relação a um sistema de coordenadas fixo. Já a postura relativa é a postura de um robô em relação a outro robô do grupo. A informação de postura relativa é muito útil para os problemas de formação, como por exemplo formação de satélites, em que os robôs devem manter uma certa distância e inclinação em relação aos demais robôs, ou a um robô líder; neste caso não é necessário conhecer a postura absoluta (TABUADA; PAPPAS; LIMA, 2001).

Considerando-se o tipo de movimento do grupo é possível identificar dois tipos: simultâneo, ou seja, todos os robôs em movimento ao mesmo tempo, ou alternado, um subgrupo dos robôs parado e outro em movimento, alternadamente.

Um grupo de robôs pode ser, em relação aos sensores utilizados, do tipo homogêneo, em que todos os robôs do grupo estão equipados com os mesmos sensores internos e externos e do tipo heterogêneo, em que os robôs do grupo são compostos de diferentes dispositivos internos e externos.

\subsection{Trabalhos Relacionados}

O interesse no problema de localização cooperativa de multirrobôs existe há mais de uma década. O primeiro trabalho a tratar desse assunto é o de Kurazume, Nagata e Hirose (1994). Os autores estavam preocupados com o fato de que a localização puramente baseada em dead reckoning não era confiável e para reduzir os erros de localização provenientes de odometria, utilizaram um grupo de robôs cooperativos. 
A idéia principal do trabalho é que os robôs são divididos em dois grupos, enquanto um grupo se move no ambiente o outro permanece parado e vice-versa. A motivação é que os robôs sirvam como marcos para localização. Esta abordagem permite a localização dos robôs sem o conhecimento de um mapa do ambiente, sendo que os próprios robôs servem como marcos móveis. O processo começa com um grupo de robôs estacionários que conhecem suas posturas. O grupo de robôs em movimento realiza um movimento de uma certa distância e então pára. Os robôs que estavam em movimento utilizam as informações de postura relativa ao grupo de robôs parados mais as informações locais para estimar suas posturas. Os grupos então invertem os papéis.

A observação das posturas relativas pode ser tanto realizada pelo grupo de robôs parados como pelo grupo em movimento. Os robôs podem ser heterogêneos no que se refere aos sensores utilizados, ou seja, um grupo pode estar equipado com um laser e o outro com algum tipo de marco facilmente identificado pelo laser. As informações coletadas pelos sensores são distância, direção e elevação. O estado do robô é dado por $(x, y, z)$, em que $(x, y)$ refere-se a posição do robô e z corresponde a elevação na superfície. As posturas dos robôs são encontradas através de restrições geométricas.

O fato de que pelo menos um robô deve estar parado enquanto os demais se movimentam é uma desvantagem, uma vez que a velocidade do grupo como um todo é retardada. Entre outras restrições, o robô que conhece sua postura deve ser visto por vários outros robôs e mais ainda, para um grupo grande de robôs, é preciso que pelo menos um grupo pequeno deles possa ver ou ser visto pelo robô referência.

No trabalho de Rekleitis, Dudek e Milios (2002) é feita uma análise comparativa entre o tipo de informação sensorial disponível para os robôs e a acurácia da informação de localização (erro médio da postura do robô) para localização cooperativa de multirrobôs. Considera-se um sensor que retorna informação no sistema de coordenadas do robô observador. São considerados três tipos de informação sensorial: distância relativa entre os robôs, posição e postura dos robôs observados.

Foram realizados experimentos em ambiente simulado com as diferentes informações sensoriais e com diferentes números de robôs (3, 5 e 10). Os menores erros de localização foram obtidos com as informações de postura, posição e distância, respectivamente. Os resultados sempre melhoram com o aumento no número de robôs. Além disso, observou-se que para um grupo com poucos 
robôs obtém-se maiores benefícios utilizando mais informação sensorial do que para grupos maiores.

O algoritmo de localização necessita de um grupo de três ou mais robôs, em que dois robôs permanecem parados enquanto um robô se movimenta. Os dois robôs parados observam o robô em movimento e medem sua postura relativa. O robô em movimento utiliza as leituras comunicadas pelos robôs estáticos para estimar sua postura. A estimativa da postura é calculada utilizando filtro de partículas.

Os trabalhos mais recentes sobre localização cooperativa de multirrobôs não mais utilizam a idéia de dois grupos de robôs, um em movimento e outro estacionário, mas permitem que todos os robôs do grupo se movimentem simultaneamente.

O método proposto por Fox (2000) para solucionar o problema de localização cooperativa de um grupo de robôs móveis é baseado na localização de Markov, inicialmente proposta para localização de um único robô, acrescido de um modelo de detecção. Neste método os robôs conhecem uma mesma representação do ambiente e realizam a estimação de suas posturas individualmente, utilizando as observações do ambiente e de movimento. Quando um robô detecta outro, ambos os robôs atualizam suas crenças de postura utilizando as informações da detecção. O robô que detectou comunica para o robô detectado a crença de sua própria postura e a distância relativa entre eles. O robô detectado, por sua vez, comunica para o robô que o detectou a crença de sua própria postura. Nesse momento, ambos os robôs podem atualizar individualmente suas crenças de postura, tendo como informação a crença de postura do outro robô e a distância entre eles. Esta comunicação melhora a estimativa das posturas dos robôs significativamente quando comparada com a auto-localização.

Howard, Mataric e Sukhatme (2002) solucionam o problema de localização para multirrobôs cooperativos, em que os robôs do grupo se localizam uns em relação aos outros. As informações utilizadas pelos robôs para se localizarem são as suas informações internas dos deslocamentos realizados e as observações de postura relativa aos demais robôs. O cálculo da localização de todos os robôs do grupo é realizada de forma centralizada. Todos os robôs comunicam todas as suas leituras sensoriais (movimento e detecção) para um computador central, e este, por sua vez estima a postura de cada robô do grupo.

A estimação das posturas é calculada através do método de Estimação por Verossimilhança Máxima (Maximum Likelihood Estimation) (MLE). Sejam o 
conjunto de todas as posturas dos robôs dado por $X$, o conjunto de todos os movimentos realizados pelos robôs dado por $M$ e o conjunto de todas as observações (medidas de postura relativas) dado por $O$. A estimação das posturas é obtida encontrando o conjunto $X$ que maximize a probabilidade de obter os conjuntos $(M, O)$, ou seja, $X$ é obtido maximizando a probabilidade condicional $P(M, O \mid X)$.

Para solucionar o problema de estimação deve-se considerar a dimensionalidade de cada um dos conjuntos $X, O$ e $M$. A solução encontrada foi manter uma janela de tempo e considerar apenas as observações e estimações dentro da janela $t-T$, onde $t$ é o tempo atual e $T$ é o tamanho da janela temporal. Outra restrição utilizada está no número de observações utilizadas para cada par de posturas estimadas. Desta forma, é possível ponderar acurácia da localização com custo computacional manipulando o tamanho da janela $T$ e o número máximo de observações por estimação.

Outra solução para o problema de localização para multirrobôs cooperativos é apresentada por Howard, Mataric e Sukhatme (2003). Cada robô do grupo pode estimar a postura de todos os outros robôs em relação a si mesmo. Cada robô está equipado com sensores de movimento e de detecção e todas as informações obtidas são comunicadas para todos os robôs do grupo.

A estimação das posturas é calculada utilizando o filtro de partículas. Para um grupo de $M$ robôs, cada robô estima as posturas dos $M-1$ robôs, mantendo um filtro de partículas para cada um deles. Considerando um robô $R$ como sendo a origem do sistema de coordenadas, $R$ atualiza a postura de cada um dos seus colegas utilizando 5 tipos de informação: seu próprio movimento, o movimento de um robô $R_{i}$, a observação da postura relativa entre dois robôs em três situações: quando $R$ observa um robô $R_{i}$, quando um robô $R_{i}$ observa o robô $R$ e quando um robô $R_{i}$ observa um outro robô $R_{j}$.

Uma desvantagem desse método é o fato de cada robô manter um filtro de partículas para cada um dos outros robôs do grupo. O custo computacional dessa técnica aumenta com o aumento do número de robôs, tornando-se inviável para grupos muito grandes.

Uma outra abordagem apresentada por Roumeliotis e Bekey (2002) e Madhavan, Fregene e Parker (2002) estima as posturas dos robôs utilizando o filtro de Kalman estendido centralizado, sendo que o estado a ser estimado é a postura de todos os robôs do grupo. O FKE centralizado possui a vantagem de manter as relações de interdependência entre os robôs, através dos termos de correlação 
cruzada. No entanto, a atualização do estado e da matriz de covariância para estados muito grandes possui a desvantagem do alto custo computacional. Para solucionar este problema, os cálculos do estado e da matriz de covariância foram distribuídos entre os robôs.

Cada robô do grupo está equipado com um sensor de movimento, um sensor que identifica outro robô e mede a postura relativa entre eles e um dispositivo de comunicação. Assume-se independência de movimentos, ou seja, o movimento de um robô não interfere no movimento do outro robô. Dessa forma, cada robô $i$ é responsável por atualizar o seu estado e sua matriz de covariância $P_{i i}$. O cálculo do termo de correlação cruzada, $P_{i j}$, é distribuído entre os robôs $i$ e $j$.

Quando o robô $i$ encontra o robô $j$, o robô $i$ mede a postura relativa entre eles. Nesse momento os dois robôs atualizam seus estados com esta observação, sendo que cada robô é responsável pela atualização do seu próprio estado e da sua parte da matriz de covariância. Os termos de correlação cruzada $P_{i j}=P_{j i}$ têm que ser atualizados, podendo este cálculo ser efetuado por qualquer um dos robôs. Após a detecção, esta informação é propagada para o resto do grupo através da atualização dos termos de correlação cruzada, nomeados $P_{i k}=P_{k i}$ e $P_{j k}=P_{k j}$, onde $k$ representa os $M-2$ robôs do grupo.

O interessante desse método está na forma em que as equações do FKE foram distribuídas entre os robôs. O cálculo da matriz de covariância de tamanho $(M \times 3) \times(M \times 3)$, foi dividido em vários cálculos de matrizes de tamanho $(3 \times 3)$, onde $M$ é o número de robôs do grupo e 3 é o tamanho do vetor de postura de cada robô.

Uma desvantagem desse método é que a utilização do FKE como algoritmo de localização permite apenas localização local, ou seja, os robôs devem conhecer sua postura inicial.

Um método diferente dos demais é apresentado por Schmitt (2002), em que a estimação cooperativa de estado é realizada no âmbito do futebol de robôs. O estado a ser estimado para cada robô consiste de sua própria postura, da posição da bola, da postura dos seus colegas e da posição dos robôs adversários. As posturas dos colegas não são realmente estimadas, mas sim recebidas pelos robôs. Assim, cada robô comunica para os seus colegas a sua própria estimativa de postura.

Os robôs mantêm um mapa, ou representação do ambiente. Para estimar a própria postura, cada robô utiliza informações das características do ambiente, da 
sua estimativa de postura anterior e da posição da bola. Para estimar a posição da bola são utilizadas a posição anterior da bola, a postura atual do robô realizando a estimação e as posições da bola comunicadas pelos colegas. Cada robô mantém uma posição distinta de bola. Os estimadores de postura e da posição da bola utilizam o método de Máximo a Posteriori (MAP). Neste método o estado $X$ é estimado por: $X=\arg \max _{X} p(X) p($ dados $\mid X)$, onde dados são as informações que o estimador recebe como entrada.

Este método difere dos demais uma vez que não mantém um modelo de detecção entre os robôs, mas a cooperação é atingida considerando que a estimação das suas próprias posturas ocorre quando eles compartilham as informações referentes à posição da bola.

Spletzer e Taylor (2003) apresentam um método em que o objetivo não é encontrar as posturas dos robôs em si, mas as regiões de incerteza das posturas, ou seja, regiões que com certeza os robôs estão. Assume-se que os robôs estão parados e que não conhecem suas posturas.

O trabalho soluciona o problema de localização de um grupo de robôs considerando que cada robô está equipado com sensores que detectam e identificam os outros robôs, e que os robôs podem comunicar as suas leituras dos sensores uns com os outros. Os sensores considerados medem a distância e a direção do robô observado relativas ao robô observador. As informações de distância e direção impõem restrições lineares no espaço de configuração do grupo de robôs, sendo que uma configuração do grupo consiste das posturas de todos os robôs do grupo. Para gerar as restrições do espaço de configurações, assume-se que cada robô pode inferir sua orientação com um erro limitado. A união dessas restrições resulta em um politopo ${ }^{1}$ convexo $\mathcal{P}$ no espaço de configuração que representa o conjunto de configurações consistentes com as medidas dos sensores. A projeção deste politopo em subespaços apropriadamente escolhidos do espaço de configuração fornece a estimação da incerteza nos parâmetros da configuração do grupo, ou seja, a postura absoluta de um robô ou as posturas relativas de dois ou mais robôs. No entanto, encontrar a projeção exata requer tempo exponencial em relação ao número de vértices do politopo. Dessa forma, é utilizada uma aproximação das projeções usando programação linear.

Uma limitação clara deste método é a suposição inicial de que todos os robôs estejam parados, o que impõe uma forte restrição no seu uso em aplicações reais.

\footnotetext{
${ }^{1}$ generalização de polígono de qualquer dimensão para duas dimensões, e poliedro para 3 dimensões.
} 


\subsection{Discussão dos Trabalhos Relacionados}

A tabela 4.1 mostra uma classificação dos trabalhos sobre localização multirrobôs descritos na seção anterior. Considerando o tipo de informação sensorial utilizada, praticamente todas as técnicas contam com a informação de detecção, quando um robô detecta e identifica o outro, mede a distância relativa entre eles, e então, os robôs se comunicam, trocando informações sobre suas posturas.

Muitos dos trabalhos não consideram como informação sensorial a observação do ambiente, e conseqüentemente, não necessitam ter um conhecimento a priori sobre o mapa do ambiente. Para tarefas em que os robôs precisam apenas se localizar uns em relação aos outros, a informação do ambiente também não é fundamental, embora possa ser mais uma fonte de informações úteis. A vantagem da localização sem mapa utilizando robôs como marcos é que não há necessidade de conhecer a estrutura do ambiente ou armazenar sua representação. A localização sem mapa é útil nas aplicações de busca e salvamento em que a estrutura do ambiente está destruída ou indisponível.

Ainda, por se tratar de localização de robôs móveis, a informação do movimento dos robôs é fundamental. Apenas no trabalho de Spletzer e Taylor (2003) a informação de movimento não é considerada, uma vez que restringe seu uso para robôs parados, impondo uma forte restrição para que o método possa ser utilizado em diversas aplicações reais.

O tipo de informação de postura que os robôs utilizam depende das tarefas que os mesmos devem executar. Um grupo de robôs que deve entregar as correspondências em um prédio necessita de informação de localização absoluta para encontrar as salas. Já robôs que devem colaborar no transporte de caixas, devem manter a informação de localização relativa para que todos mantenham-se em uma formação adequada para poderem carregar a caixa.

A maioria dos trabalhos utiliza o filtro de partículas como algoritmo de localização. A vantagem dessa técnica é que possibilita a localização global, com um custo computacional menor em relação à localização de Markov. 


\begin{tabular}{|c|c|c|c|c|c|c|c|}
\hline Método Proposto em: & $\begin{array}{c}\text { Informação } \\
\text { Sensorial }\end{array}$ & Mapa & $\begin{array}{c}\text { Tipo de } \\
\text { Localização }\end{array}$ & $\begin{array}{l}\text { Informação } \\
\text { de Postura }\end{array}$ & $\begin{array}{c}\text { Algoritmo de } \\
\text { Localização } \\
\end{array}$ & Arquitetura & Movimento \\
\hline (KURAZUME; NAGATA; HIROSE, 1994) & $\begin{array}{l}\text { Movimento } \\
\text { Detecção }\end{array}$ & Não & Local & Absoluta & triangulação & Descentralizada & Alternado \\
\hline (REKLEITIS; DUDEK; MILIOS, 2002) & $\begin{array}{c}\text { Movimento } \\
\text { Detecção }\end{array}$ & Não & Local & Relativa & FP & Descentralizada & Alternado \\
\hline (FOX, 2000) & $\begin{array}{c}\text { Movimento } \\
\text { Observação } \\
\text { Detecção }\end{array}$ & Sim & Global & Absoluta & $\mathrm{FP}$ & Descentralizada & Simultâneo \\
\hline (HOWARD; MATARIC; SUKHATME, 2002) & $\begin{array}{l}\text { Movimento } \\
\text { Detecção }\end{array}$ & Não & Global & Relativa & MLE & Centralizada & Simultâneo \\
\hline (HOWARD; MATARIC; SUKHATME, 2003) & $\begin{array}{l}\text { Movimento } \\
\text { Detecção }\end{array}$ & Não & Global & Relativa & $\mathrm{FP}$ & Descentralizada & Simultâneo \\
\hline $\begin{array}{c}\text { (ROUMELIOTIS; BEKEY, 2002) e } \\
\text { (MADHAVAN; FREGENE; PARKER, 2002) }\end{array}$ & $\begin{array}{l}\text { Movimento } \\
\text { Detecção }\end{array}$ & Não & Local & Absoluta & FKE & Distribuída & Simultâneo \\
\hline (SCHMITT, 2002) & $\begin{array}{l}\text { Movimento } \\
\text { Observação }\end{array}$ & Sim & Local & Absoluta & MAP & Descentralizada & Simultâneo \\
\hline (SPLETZER; TAYLOR, 2003) & Detecção & Não & Global & $\begin{array}{c}\text { Absoluta/ } \\
\text { Relativa } \\
\end{array}$ & $\begin{array}{c}\text { Projeção de } \\
\text { Politopo }\end{array}$ & Descentralizada & Simultâneo \\
\hline
\end{tabular}

Tabela 4.1: Classificação de trabalhos de localização cooperativa de multirrobôs. 
Em relação à arquitetura, a grande maioria dos trabalhos utiliza a arquitetura descentralizada, que parece ser a mais adequada. As vantagens desta arquitetura são: a computação da postura pode ser distribuída entre os robôs do grupo; por não haver um robô líder, o desempenho do grupo não depende de um único robô; e como toda computação é realizada localmente, não é necessário um conhecimento global a priori da topologia da rede dos robôs.

E por fim, o movimento de todos os robôs simultaneamente é o mais adequado, sendo também o mais utilizado. Esta maneira de movimentação dos robôs possibilita uma maior velocidade do grupo como um todo, além de não necessitar que os subgrupos de robôs sincronizem seus movimentos para executá-los de forma alternada.

Na próxima seção o modelo de detecção é apresentado com mais detalhes, uma vez que é a informação de detecção que determina a cooperação nos trabalhos de localização multirrobôs.

\subsection{Modelo de Detecção}

A localização cooperativa de um grupo de robôs é realizada através do uso das informações obtidas com uma detecção. Uma detecção é a situação em que um robô detecta e identifica outro, e mede a distância relativa entre eles. Com estas informações os dois robôs envolvidos podem atualizar suas crenças de postura.

As informações de uma detecção podem ser obtidas com sensores capazes de identificar outros robôs e medir a distância entre eles. Estas informações podem ser obtidas, por exemplo, com uma câmera, em que a identificação dos robôs é feita por reconhecimento de padrões de cores. Um sistema de visão esteroscópica ou um sensor a laser utilizado em conjunto com as imagens de uma câmera podem determinar a distância até o robô identificado. Os sensores utilizados para detecção definem um alcance e ângulo de abertura, que determina a área de alcance de percepção dos robôs. A Figura 4.1 ilustra a área de percepção, ou campo de visão, para um robô.

Na localização probabilística para um robô, como apresentada no Capítulo 3, a estimativa de sua postura é atualizada toda vez que o robô recebe uma nova leitura dos sensores. Essa leitura pode ser uma observação do ambiente ou uma informação do movimento do robô, sendo necessários dois modelos, um modelo de observação e um modelo de movimento, respectivamente. Para lidar com a localização de um grupo de robôs foi inserido por Fox (2000) um novo modelo aos 


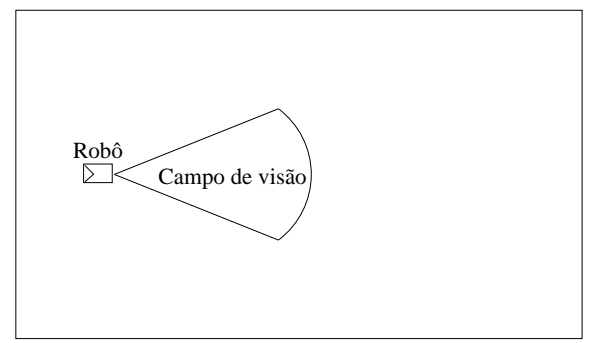

Figura 4.1: Campo de visão de um robô.

dois anteriores, este chamado de modelo de detecção. Tal modelo representa a estimativa de postura de dois robôs, quando um dos robôs encontra e identifica o outro, fazendo uma medida de distância relativa entre eles.

Neste caso, o conjunto de leituras dos sensores até o tempo $t$ para um grupo de $M$ robôs é dado por $d_{t}=\left\{d_{t}^{1} \cup d_{t}^{2} \cup \ldots \cup d_{t}^{M}\right\}$.

No momento que o robô $n$ detecta o robô $m$, a atualização da postura do robô $n$ é dada por:

$$
p\left(\mathbf{x}_{t}^{n}=x \mid d_{t}\right)=p\left(\mathbf{x}_{t}^{n}=x \mid d_{t}^{n}\right) \sum_{x^{\prime}} p\left(\mathbf{x}_{t}^{n}=x \mid \mathbf{x}_{t-1}^{m}=x^{\prime}, \mathbf{r}_{t}^{n}\right) p\left(\mathbf{x}_{t-1}^{m}=x^{\prime} \mid d_{t-1}^{m}\right),
$$

onde $\mathbf{x}_{t}^{n}$ é a postura do robô $n, \mathbf{x}_{t}^{m}$ representa a postura do robô $m$ e $\mathbf{r}^{n}$ é a distância relativa entre os dois robôs, como medida pelo robô $n$. O cálculo $\sum_{x^{\prime}} p\left(\mathbf{x}_{t}^{n}=x \mid \mathbf{x}_{t-1}^{m}=x^{\prime}, \mathbf{r}_{t}^{n}\right) p\left(\mathbf{x}_{t-1}^{m}=x^{\prime} \mid d_{t-1}^{m}\right)$ descreve a crença do robô $n$ sobre a postura do robô detectado. De forma simétrica, a mesma detecção é utilizada para atualizar a estimativa de postura do robô $m$.

Uma vez ocorrida uma detecção, os dois robôs envolvidos atualizam suas estimativas de postura, compartilhando suas crenças de postura e a distância relativa entre eles. Para o caso dos dois robôs $n$ e $m$, quando o robô $n$ detecta o robô $m$, o robô $n$ envia para $m$ sua estimativa de postura e a distância relativa entre eles e o robô $m$, por sua vez, envia sua estimativa de postura para $n$. Cada um dos robôs atualiza sua respectiva estimativa de postura com as informações recebidas, utilizando a Equação 4.1.

O algoritmo para Localização de Markov para Multirrobôs (LMM) pode ser visto no Algoritmo 3, conforme o algoritmo 1 apresentado no Capítulo 3 e acrescido do modelo de detecção de Fox (2000). Vale ressaltar que neste trabalho de Fox (2000) o modelo para observação negativa não é utilizado. O modelo de observação negativa apresentado no Algoritmo 3 foi proposto e incorporado na LM por Hoffmann (2005).

A atualização das crenças de posturas dos robôs utilizando observação do 
ambiente ou detecção de outros robôs deve ocorrer com os robôs parados, uma vez que o modelo de localização de Markov especifica que movimento e sensoriamento se alternam e que, em cada uma destas atividades, o robô atualiza sua crença de postura. As crenças de posturas dos robôs são calculadas intercalando informação dos sensores externos com informação dos movimentos dos robôs, estas últimas dadas pelos sensores internos.

\subsection{Modelo de Arquitetura para Localização de Multirrobôs}

A extensão da tarefa de localização de um robô móvel em um ambiente para a localização de um grupo de robôs apresenta algumas modificações no modelo de arquitetura para localização. Para localização de multirrobôs é necessário ter uma camada de comunicação que permita que os robôs se comuniquem de forma a compartilhar informações. Para tal é utilizado um modelo de detecção que trata uma nova fonte de informações, que ocorre quando um robô detecta outro, e um modelo comunicação que trata da troca de informações. O modelo de arquitetura para localização multirrobôs é apresentado na Figura 4.2.

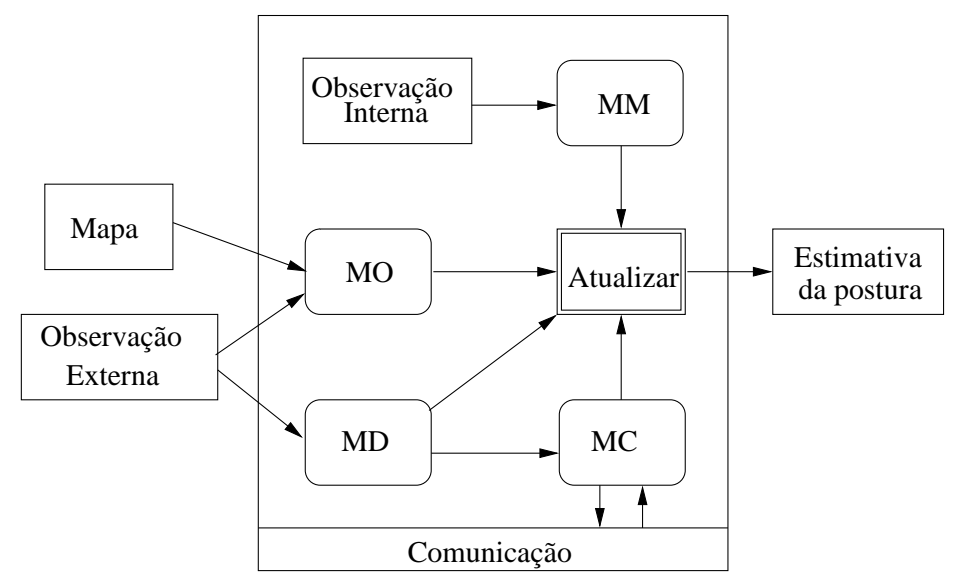

Figura 4.2: Modelo de arquitetura para localização de multirrobôs.

O Modelo de Detecção (MD) obtém informações dos sensores externos que identificam outros robôs do grupo, além de medir a distância relativa entre eles. Neste modelo é iniciado o processo de comunicação para que os robôs envolvidos na detecção possam atualizar suas crenças de postura utilizando a informação de distância relativa entre eles e a crença de postura um do outro. O robô que efetuou a detecção necessita trocar informações com o robô detectado, para que possam atualizar suas estimativas de postura. A troca de informações entre os robôs é feita utilizando-se o Modelo de Comunicação (MC). 


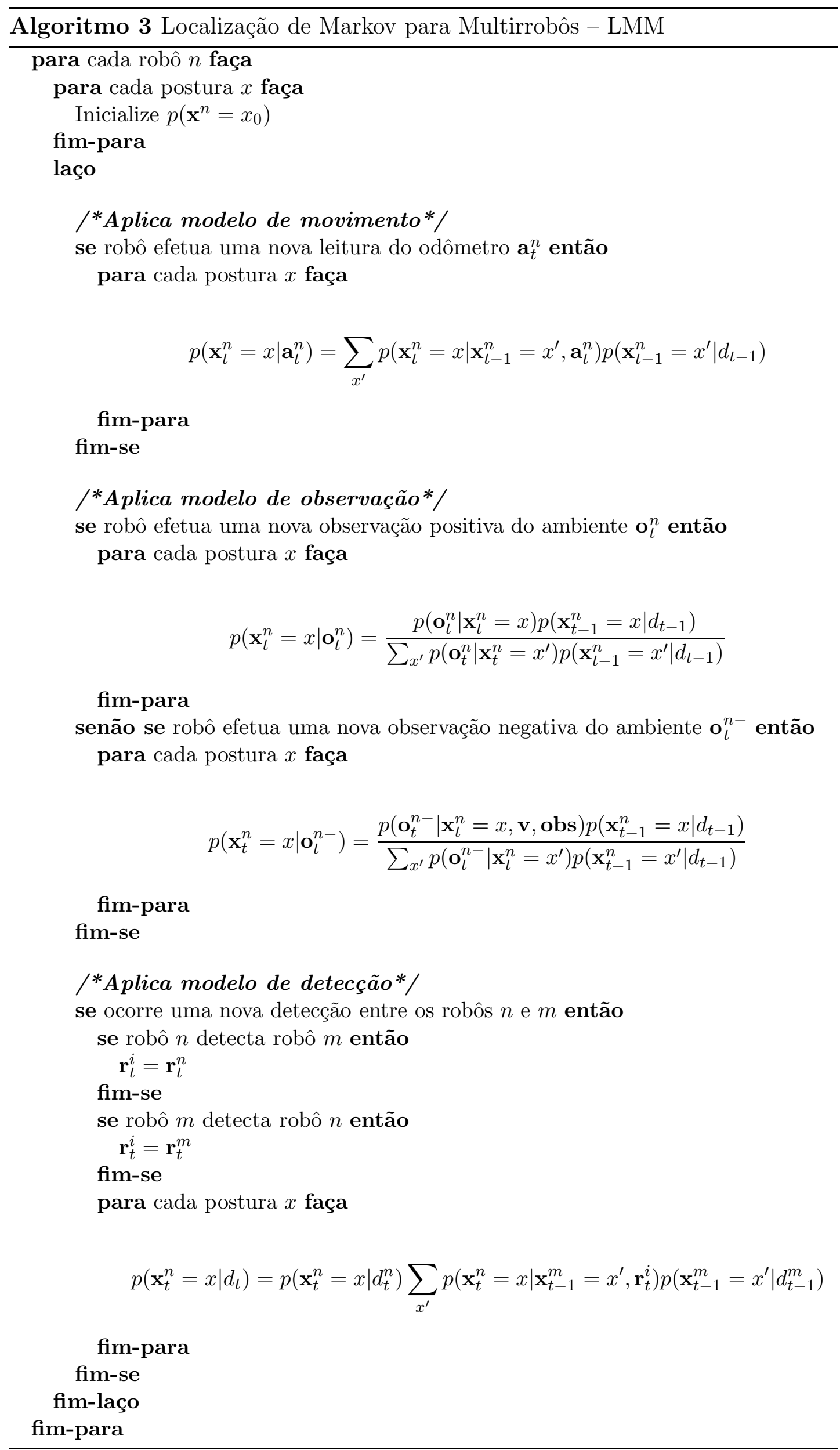


Desta maneira, o processo de comunicação pode ser iniciado pelo MC nos casos em que uma detecção ocorre. O robô que detecta inicia o processo de comunicação, enviando mensagens para os robôs detectados, com as informações:

- Identidade do robô que efetuou a detecção.

- A distância relativa entre o robô que detectou e o detectado.

- A crença de postura do robô que efetuou a detecção.

O robô detectado, após receber mensagem do robô que o detectou, envia uma mensagem de resposta, contendo:

- Identidade do robô detectado.

- A crença de postura do robô detectado.

Cada um dos robôs, o que detectou e o detectado, de posse das informações de distância relativa e das crenças de posturas dos dois robôs, atualiza sua própria crença de postura.

O MC recebe o conteúdo da mensagem que deve ser transmitida e a identidade do robô que vai receber a mensagem. O MC prepara a mensagem para ser enviada, com base no conhecimento dos protocolos e linguagens de comunicação utilizados para transmissão de informação. Os itens que devem constar obrigatoriamente da mensagem são: a identidade do emissor, a identidade do receptor e o conteúdo da mensagem.

A localização de multirrobôs pode acontecer com ou sem mapa. No caso de o mapa não estar disponível, os robôs podem utilizar suas observações internas e suas detecções para atualizarem as suas crenças de posturas. Neste caso, os robôs podem obter informações de localização relativa aos demais robôs do grupo.

O modelo de arquitetura para localização de multirrobôs é descentralizado, uma vez que cada robô atualiza sua estimação de postura localmente, utilizando suas informações locais e as informações comunicadas pelos demais robôs do grupo.

\subsection{Representação Fatorada}

A localização multirrobôs utilizando o modelo de detecção é baseada em uma representação fatorada. Nesta representação assume-se que a distribuição das 
posturas de todos os robôs é o produto de suas distribuições marginais. Para um grupo de $M$ robôs tem-se:

$$
p\left(\mathbf{x}_{t}^{1}, \mathbf{x}_{t}^{2}, \cdots, \mathbf{x}_{t}^{M} \mid d\right)=p\left(\mathbf{x}_{t}^{1} \mid d\right) \cdot p\left(\mathbf{x}_{t}^{2} \mid d\right) \cdot \cdots \cdot p\left(\mathbf{x}_{t}^{M} \mid d\right)
$$

onde $d$ é toda informação obtida pelos robôs, que inclui as observações do ambiente, medidas do movimento e detecções. A suposição de independência entre as distribuições de posturas dos robôs deixa de ser verdade quando os robôs compartilham suas crenças de postura. Por exemplo, quando o robô $R 1$ encontra $R 2$, o robô $R 1$ atualiza sua crença de postura usando a crença de postura do robô $R 2$, o que resulta em $p\left(\mathbf{x}_{t}^{1}\right)=p\left(\mathbf{x}_{t}^{1} \mid \mathbf{x}_{t}^{2}\right)$, o que contradiz a suposição de independência.

Assim, a distribuição das posturas de todos os robôs não é o produto da suas distribuições marginais, sendo a representação fatorada apenas uma aproximação da distribuição verdadeira. A distribuição das posturas de todos os robôs é de fato:

$$
p\left(\mathbf{x}_{t}^{1}, \mathbf{x}_{t}^{2}, \cdots, \mathbf{x}_{t}^{M} \mid d\right)=p\left(\mathbf{x}_{t}^{1} \mid \mathbf{x}_{t}^{2}, \cdots, \mathbf{x}_{t}^{M}, d\right) \cdot p\left(\mathbf{x}_{t}^{2} \mid \mathbf{x}_{t}^{3}, \cdots, \mathbf{x}_{t}^{M}, d\right) . \cdots \cdot p\left(\mathbf{x}_{t}^{M} \mid d\right),
$$

que é computacionalmente muito custosa, com custo crescente com o aumento do número de robôs no grupo.

A representação fatorada possui a vantagem de que a estimativa da postura é realizada localmente para cada robô, o que significa uma representação computacionalmente tratável, uma vez que a computação da distribuição conjunta das posturas pode ser intratável.

A desvantagem em se representar a distribuição conjunta $p\left(\mathbf{x}_{t}^{1}, \cdots, \mathbf{x}_{t}^{M} \mid d\right)$ como uma distribuição fatorada aproximada é que aproximações repetidas podem levar a erros que crescem com o tempo. Para minimizar essa desvantagem, Fox (2000) incluíram um contador que, uma vez que um robô é detectado, bloqueia a habilidade de outro robô detectar novamente o mesmo robô até que o robô detectado tenha percorrido uma distância pré-determinada. A razão de bloquear a comunicação entre os robôs por um certo período faz com que a estimação da postura do robô detectado seja atualizada com informações do ambiente e do seu movimento, que são independentes dos outros robôs do grupo.

Boyen e Koller (1998) e Boyen e Koller (1999) mostraram que a estocasticidade do processo serve para atenuar os efeitos do erro sobre o tempo, de maneira rápida o suficiente para prevenir que erros acumulem indefinidamente. A idéia é que o erro seja baixo se a interação entre as variáveis for fraca. A intensidade 
de interação fraca ou forte está relacionada com a quantidade de correlação gerada entre as variáveis em uma iteração do processo. Partindo do princípio que, na maioria dos sistemas, na maior parte do tempo ocorrem interações fracas e em alguns momentos ocorrem interações fortes, o sistema pode ser atualizado utilizando a aproximação fatorada na maior parte do tempo, e em alguns casos, quando uma interação forte ocorre, a atualização do sistema pode ser feita ajustando a aproximação para tratar das correlações.

Seguindo a mesma linha, Engelen (1997) mostra que há um limite superior no erro da distribuição de probabilidade aproximada. O limite é calculado utilizando a entropia relativa ou divergência de Kulback-Leibler, e serve para medir quão bem uma distribuição de probabilidade conjunta pode ser aproximada por outra distribuição com uma estrutura de dependência mais simples, de forma que:

$$
I\left(p(\mathbf{x}), p^{\prime}(\mathbf{x})\right)=\sum p(\mathbf{x}) \log \frac{p(\mathbf{x})}{p^{\prime}(\mathbf{x})}
$$

onde $p$ é a distribuição real, $p^{\prime}$ é a distribuição aproximada, ambas sobre o mesmo espaço de estados. O valor de $I$ é uma medida de discrepância entre as duas distribuições.

Para distribuição de probabilidade a priori a divergência de Kulback-Leibler satisfaz:

$$
\left|p(\mathbf{x})-p^{\prime}(\mathbf{x})\right| \leq \sqrt{\frac{1}{2} I\left(p(\mathbf{x}), p^{\prime}(\mathbf{x})\right)},
$$

que fornece um limitante superior para o erro absoluto máximo entre as distribuições $p$ e $p^{\prime}$.

Para a distribuição de probabilidade a posteriori a divergência de KulbackLeibler satisfaz:

$$
\left|p(\mathbf{x} \mid \mathbf{o})-p^{\prime}(\mathbf{x} \mid \mathbf{o})\right| \leq \sqrt{\frac{I\left(p(\mathbf{x}), p^{\prime}(\mathbf{x})\right)-I\left(p(\mathbf{x} \mid \mathbf{o}), p^{\prime}(\mathbf{x} \mid \mathbf{o})\right)}{2 p(\mathbf{o})}}
$$

que fornece um limitante superior para o erro absoluto máximo entre as distribuições $p$ e $p^{\prime}$, dada alguma evidência $\mathbf{o}$.

A representação fatorada tem sido utilizada para lidar com o problema de manter uma distribuição de probabilidade conjunta de forma aproximada em alguns problemas de estimação de estado como em (KOLLER; FRATKINA, 1998) e (NG; PESHKIN; PFEFFER, 2002).

Considerando os resultados de Boyen e Koller (1998) e Engelen (1997) para o problema de estimação de postura para um grupo de robôs, pode-se considerar que ocorre interação fraca enquanto os robôs não estão se comunicando, ou seja, 
enquanto atualizam suas posturas apenas com suas informações locais. Quando acontece uma comunicação, por ter uma informação de detecção, a interação entre os estados dos robôs é forte. Neste caso, pode-se utilizar a solução apresentada por Fox (2000) para bloquear outras trocas de mensagens entre os robôs, até que o efeito da interação forte se atenue, forçando o sistema a ter apenas interações fracas neste período, à medida que só atualiza as posturas com informações locais. Desta forma, é possível garantir que a atualização das posturas dos robôs utilizando representação fatorada é uma solução computacionalmente tratável, em que os erros existentes devido à aproximação são limitados.

\subsection{Considerações Finais}

A cooperação na localização para multirrobôs pode ser alcançada quando os robôs compartilham informações de forma a melhorar as estimativas das posturas de todos os robôs do grupo. A idéia é que os robôs utilizem mais informações do que apenas suas informações locais, enriquecendo a percepção de um robô através da obtenção das percepções de outros robôs, através da comunicação.

Na maioria dos casos a informação compartilhada baseia-se na detecção e identificação de um robô e troca das suas crenças de postura, sendo o modelo de detecção adicionado aos modelos de observação e movimento, de forma a permitir a atualização das posturas dos robôs com as informações comunicadas. Apesar do tratamento dado para a estimação de postura utilizando o modelo de detecção ser uma aproximação da distribuição real, os erros inseridos devido à aproximação são limitados. A vantagem de se utilizar tal aproximação é que a estimativa das posturas dos robôs torna-se computacionalmente tratável. 


\section{Proposta do Modelo Geral de Deteç̧ão}

A proposta da tese é apresentar uma solução para o problema de localização para multirrobôs cooperativos. O problema de localização de multirrobôs consiste em localizar cada robô do grupo dentro de um mesmo ambiente. A cooperação entre os robôs é alcançada através da comunicação de informações sobre suas crenças de postura. A idéia norteadora é que a informação comunicada pelos robôs pode ser orientada não somente às detecções positivas, mas também às negativas ou ainda à propagação, para todos os robôs, das detecções positivas. Em todos os casos os robôs compartilham informações referentes às suas crenças de postura, compartilhando seu conhecimento para melhorar as estimativas de postura de todos os robôs do grupo.

Partindo do modelo de arquitetura para localização de multirrobôs apresentado no Capítulo 4, é apresentada uma instanciação do modelo para estimar as posturas dos robôs do grupo, considerando como objetivos:

- Realizar localização global;

- Obter informações de posturas absolutas;

- Utilizar uma arquitetura descentralizada para estimativas das posturas.

Para isso, considera-se:

- O conhecimento a priori de uma mesma representação do ambiente por todos os robôs, em forma de um mapa de grades;

- Os robôs conhecem a identidade de todos os robôs do grupo do qual fazem parte;

- Os robôs são heterogêneos no que concerne os tipos de sensores que possuem: os robôs podem ter diferentes sensores internos e externos, com diferentes áreas de alcance e acurácia; 
- Todos os robôs possuem mecanismos de comunicação;

- O algoritmo de localização utilizado é a localização de Markov.

O modelo de detecção apresentado no modelo de arquitetura para localização de multirrobôs, como mostra a Figura 5.1, é estendido neste capítulo. Nas seções seguintes são propostos os modelos de detecção negativa, propagação de detecção positiva e multidetecção, que compõem o Modelo Geral de Detecção (MGD), proposto nesta tese. Estes novo MGD é integrado na localização de Markov para multirrobôs. O algoritmo resultante é apresentado na Seção 5.4.

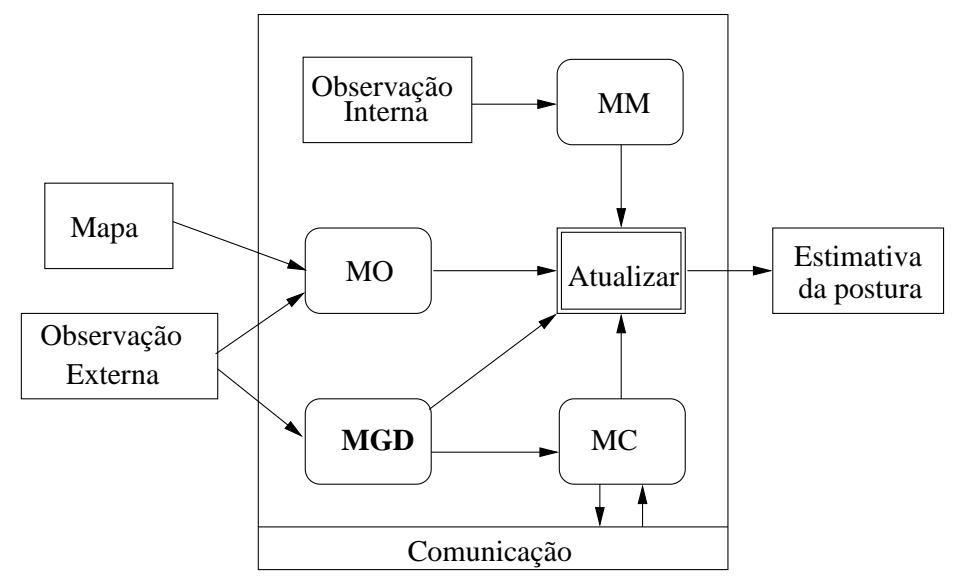

Figura 5.1: Modelo de arquitetura para localização de multirrobôs.

\subsection{Modelo de Detecção Negativa}

Uma medida de informação negativa significa que, em um dado instante de tempo, espera-se que o sensor retorne uma leitura, que de fato não ocorre. Se a leitura esperada é um marco no ambiente, e este não está localizado na área de visibilidade do sensor, e uma vez que se sabe que o marco existe, ele está com certeza fora da área de visibilidade do mesmo. Este princípio foi utilizado por Koch (2004) e por Särkkä (2004) para rastreamento de objetos, e por Hoffmann (2005) para incorporar observações negativas na localização de robôs móveis. A observação negativa, ou seja, a ausência de medidas de marcos, foi incorporada na localização de Markov através de um modelo de observação negativa. O algoritmo 1, LM, incorporou o modelo de observação negativa para o caso de localização de um único robô e o algoritmo 3, LMM, fez o mesmo para o caso de multirrobôs.

No entanto, observa-se que na localização para multirrobôs cooperativos, a informação negativa pode também significar a ausência de detecções (no caso de um robô não detectar outro), o que configura falta de informação de grupo. Neste 
caso, a medida de deteç̧ão negativa pode fornecer a informação útil de que um robô não está localizado na área de visibilidade de outro robô. Em alguns casos, esta pode ser uma informação essencial para melhorar a estimativa de postura de um robô que está isolado em uma parte do ambiente com poucos marcos discriminantes.

Considere dois robôs dentro de um mesmo ambiente. Se o robô $R 1$ não detecta o robô $R 2$, uma informação negativa é fornecida, de que o robô $R 2$ não está na área de visibilidade de $R 1$, como pode ser visto na Figura 5.2(a). A informação obtida da Figura 5.2(a) é verdadeira se for considerado que não houve nenhuma oclusão. Para verificar se obstáculos estão obstruindo o campo de visão, é necessário sensoriar o ambiente para identificar áreas livres e ocupadas. Se uma área ocupada é encontrada pelos sensores, isto significa que um robô pode não ser detectado por estar sendo escondido por um outro robô ou um obstáculo. Neste caso é possível utilizar inferência geométrica para determinar que parte da área de visibilidade pode ser usada como informação de detecção negativa, como mostra a Figura 5.2(b), onde a área cinza indica a área onde percebeu-se que o robô $R 2$ não se encontra.

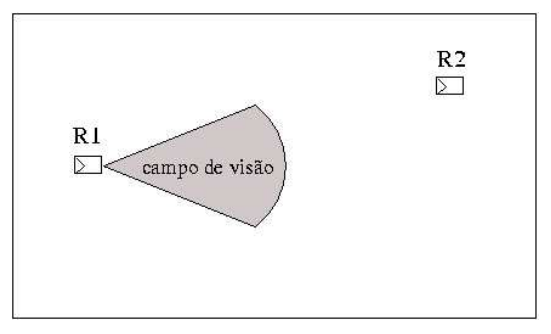

(a)

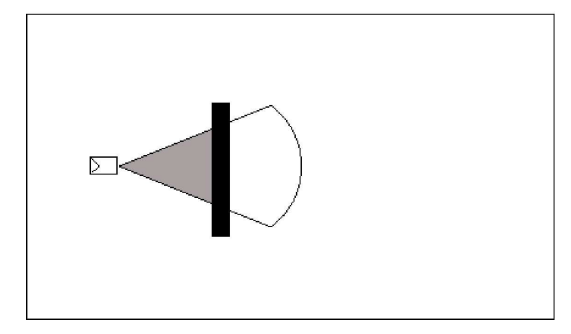

(b)

Figura 5.2: (a) Informação de detecção negativa (área branca). (b) Oclusão no campo de visão (preto: obstáculo, cinza: informação de detecção negativa).

Suponha que o robô $n$ realiza uma detecção negativa. O modelo de detecção negativa, considerando a área de visibilidade do robô e a área de oclusão, torna-se:

$$
p\left(\mathbf{x}_{t}^{n-}=x \mid \mathbf{d}_{t}^{-}\right)=\frac{p\left(\mathbf{d}_{t}^{-} \mid \mathbf{x}_{t}^{n}=x, \mathbf{v}^{n}, \mathbf{o b s}\right) p\left(\mathbf{x}_{t-1}^{n}=x \mid d_{t-1}^{n}\right)}{\sum_{x^{\prime}} p\left(\mathbf{d}_{t}^{-} \mid \mathbf{x}_{t}^{n}=x^{\prime}, \mathbf{v}^{n}, \mathbf{o b s}\right) p\left(\mathbf{x}_{t-1}^{n}=x^{\prime} \mid d_{t-1}^{n}\right)},
$$

onde $\mathbf{d}_{t}^{-}$é o evento de não detectar nenhum robô e $\mathbf{x}_{t}^{n}$ corresponde à postura do robô $n$ no tempo $t$, o robô que comunica a informação de detecção negativa. As variáveis $\mathbf{v}^{n}$ e obs representam a área de visibilidade do robô e os obstáculos identificados, respectivamente.

Toda vez que o robô $n$ não detectar outro robô $k$, pode-se atualizar a função 
distribuição de probabilidade de cada robô $k$, com $k \neq n$, da seguinte forma:

$$
p\left(\mathbf{x}_{t}^{k}=x \mid \mathbf{x}_{t}^{n-}=x\right)=\frac{p\left(\mathbf{x}_{t}^{n-}=x \mid \mathbf{d}_{t}^{-}\right) p\left(\mathbf{x}_{t-1}^{k}=x \mid d_{t-1}^{k}\right)}{\sum_{x^{\prime}} p\left(\mathbf{x}_{t}^{n-}=x^{\prime} \mid \mathbf{d}_{t}^{-}\right) p\left(\mathbf{x}_{t-1}^{k}=x^{\prime} \mid d_{t-1}^{k}\right)},
$$

onde $\mathbf{x}_{t}^{k}$, para $k=1, \cdots,(M-1)$, representa todos os robôs do grupo que não foram detectados, em um grupo de $M$ robôs.

A atualização da crença de postura com a informação de detecção negativa diminui a crença do robô que recebeu a informação estar localizado na área relativa ao alcance do sensor de detecção do robô que enviou a mensagem.

O uso do modelo de detecção negativa para atualizar a crença de postura dos robôs pode solucionar problemas de localização que não seriam possíveis caso esta informação não estivesse disponível. Um exemplo de uma situação em que a detecção negativa é determinante para uma boa localização é quando um robô ocupa uma sala em um ambiente, em que não pode detectar ou ser detectado por outros robôs. Se o ambiente possui simetrias ou ambiguidades, as observações do ambiente podem não ser suficientes para que o robô isolado em uma sala encontre sua postura. Neste caso, se um robô fora da sala, melhor localizado, informa ao robô isolado sobre quais posturas ele não está, esta informação pode reduzir a área de incerteza do robô isolado.

As contribuições relacionadas ao modelo de detecção negativa foram publicadas em (ODAKURA; COSTA, 2006b).

\subsection{Modelo de Propagação de Detecção Positiva}

Suponha que, num grupo de robôs, um robô $n$ detecta um robô $m, n \neq m$. Qual informação um robô $k$ do grupo, que não participou da detecção, pode ganhar desta detecção? O robô $k$ pode saber que sua postura não é a mesma que a postura do robô $n$ nem a mesma do robô $m$ e, ainda, que sua postura não está no caminho de detecção entre o robô $n$ e $m$; caso contrário robô $n$ teria detectado o robô $k$ e não o robô $m$. A Figura 5.3 ilustra esta situação. No exemplo há três robôs, $R 1$, $R 2$ e $R 3$ nas suas posturas reais. Em um determinado instante de tempo, os robôs têm conhecimento diferente sobre suas posturas: $R 1$ está certo sobre sua postura, $R 2$ está completamente incerto e $R 3$ está em dúvida sobre duas posturas, mostradas pelas células cinzas. Se $R 1$ detecta $R 2$, e os dois atualizam suas posturas com a informação da detecção, $R 2$ adquire certeza sobre sua postura e o $R 3$ continua em dúvida. No entanto, se a informação de detecção for compartilhada com $R 3$, este torna-se certo sobre sua postura, uma vez que 


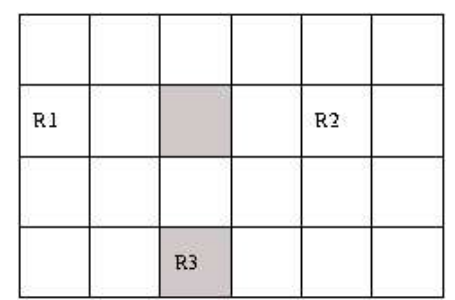

Figura 5.3: Exemplo: posturas de 3 robôs. $R 1$ está certo sobre sua postura, $R 2$ está incerto sobre sua postura e $R 3$ está em dúvida sobre sua postura (as células cinzas).

elimina a possibilidade de estar no caminho entre $R 1$ e $R 2$. O exemplo mostra a melhora na localização do grupo de robôs se a informação de detecção positiva for propagada para os demais robôs do grupo, não envolvidos na detecção.

Quando o robô $n$ detecta o robô $m$, o robô $n$ envia uma mensagem para o robô $m$, contendo sua crença de postura. A propagação da informação de detecção pode ser disparada pelo robô que realizou a detecção, no caso o robô $n$. Deste modo, a informação propagada assume a forma:

$$
\begin{aligned}
p\left(\mathbf{x}_{t}^{k_{p}}=x^{\prime \prime}\right)= & 1-\left(p\left(\mathbf{x}_{t}^{n}=x \mid d_{t}^{n}\right)+p\left(\mathbf{x}_{t}^{m}=x^{\prime} \mid d_{t}^{m}\right)+\right. \\
& \left.p_{n m}\left(\mathbf{x}_{t}^{n}=x, \mathbf{x}_{t}^{m}=x^{\prime}\right)\right)
\end{aligned}
$$

onde $p\left(\mathbf{x}_{t}^{k_{p}}=x^{\prime \prime}\right)$ é a informação comunicada para os robôs que não participaram da detecção, $p\left(\mathbf{x}_{t}^{n}=x \mid d_{t}^{n}\right)$ é a distribuição de probabilidade do robô $n, p\left(\mathbf{x}_{t}^{m}=\right.$ $\left.x^{\prime} \mid d_{t}^{m}\right)$ é a distribuição de probabilidade do robô $m$ e $p_{n m}\left(\mathbf{x}_{t}^{n}=x, \mathbf{x}_{t}^{m}=x^{\prime}\right)$ é a distribuição de probabilidade de um robô estar entre os robôs $n$ e $m$. Assim, para cada robô $k$ do grupo, com $(k \neq n)$ e $(k \neq m)$, a atualização da postura do robô $k$ é dada por:

$$
p\left(\mathbf{x}_{t}^{k}=x \mid \mathbf{x}_{t}^{k_{p}}=x\right)=\frac{p\left(\mathbf{x}_{t}^{k_{p}}=x\right) p\left(\mathbf{x}_{t-1}^{k}=x \mid d_{t-1}^{k}\right)}{\sum_{x^{\prime}} p\left(\mathbf{x}_{t}^{k_{p}}=x^{\prime}\right) p\left(\mathbf{x}_{t-1}^{k}=x^{\prime} \mid d_{t-1}^{k}\right)} .
$$

A propagação da informação de detecção positiva para os robôs que não participaram da detecção é mais uma informação útil que pode ser compartilhada pelos robôs para contribuir para uma melhor estimativa de postura.

As contribuições relacionadas ao modelo de propagação de detecção positiva foram publicadas em (ODAKURA; COSTA, 2005). 


\subsection{Modelo de Multidetecção}

O modelo de detecção apresentado por Fox (2000) considera apenas a detecção que envolve um par de robôs, o robô que detectou e o que foi detectado. No entanto, para um grupo não muito grande de robôs, não é raro que a detecção envolva mais de dois robôs, o que configura uma multidetecção. Neste seção é apresentado o problema de multidetecção, bem como é proposta uma forma de atualizar as crenças das posturas dos robôs envolvidos em uma multidetecção.

A multidetecção ocorre quando um robô detecta dois ou mais robôs ao mesmo tempo, ou quando um robô identifica outro que, por sua vez, identifica outro, como mostra a Figura 5.4.

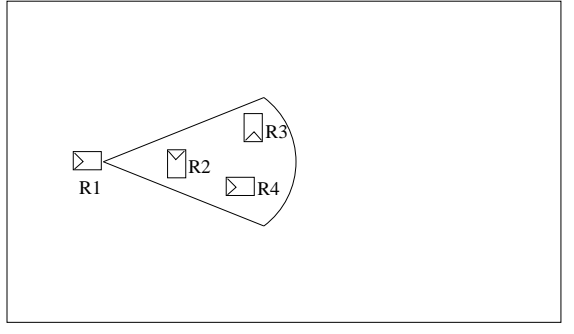

(a)

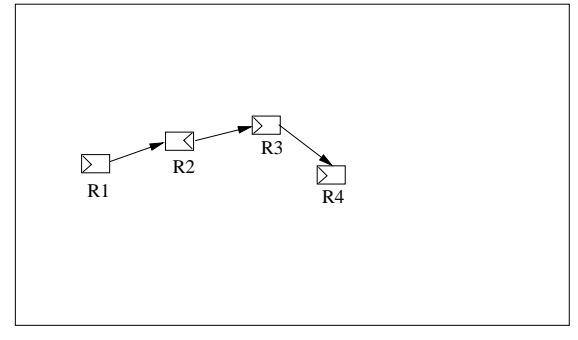

(b)

Figura 5.4: Multidetecção: (a) Robô $R 1$ detecta $R 2, R 3$ e $R 4$ (linhas ao redor dos robôs $R 2$, $R 3$ e $R 4$ representam o campo de visão de $R 1$; (b) $R 1$ detecta $R 2$, $R 2$ detecta $R 3$ e $R 3$ detecta $R 4$, ao mesmo tempo.

A situação de multidetecção para um grupo de robôs pode ser representada por um grafo orientado $G=(V, E)$, onde $V$ é o conjunto de vértices e $E$ é o conjunto de arestas direcionadas. Cada robô é representado por um vértice e cada detecção é representada por uma aresta direcionada, ligando os dois robôs que se encontraram e apontando para o robô detectado. Se o grafo possui arestas bidirecionais, significa que dois robôs estão detectando e sendo detectados um pelo outro ao mesmo tempo.

Alguns grafos representando situações de multidetecção são mostrados nas figuras seguintes. Na Figura 5.5 tem-se um conjunto de vértices, representando a situação em que não há detecções. Na Figura 5.6 tem-se um grafo desconexo que representa duas situações de multidetecção, uma envolvendo três robôs, a outra quatro, e os demais robôs não participam de nenhuma detecção. Por fim, na Figura 5.7 tem-se um grafo completo em que é representada a situação de multidetecção em que todos os robôs detectam e são detectados por todos os outros.

Dado um grafo $G=(V, E)$ representando uma situação de multidetecção, 
Figura 5.5: Grafo representando oito robôs em a situação em que não ocorre detecção.

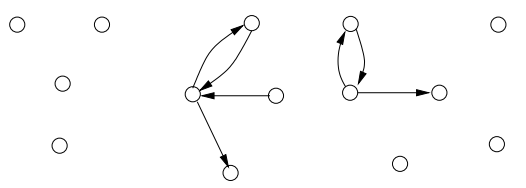

Figura 5.6: Grafo representando quatorze robôs em uma situação em que dois subgrupos de robôs participam de multidetecção.

a atualização das posturas dos robôs seguindo $G$ é computada para cada par de robôs ligados por uma aresta, seguindo o modelo de detecção positiva. No caso do grafo possuir arestas bidirecionais esta atualização precisa ser feita apenas uma vez, pois a repetição da atualização com as mesmas informações é desnecessária. Desta forma, as arestas bidirecionais devem ser convertidas para arestas unidirecionais. Para tal, dois tipos de robôs podem ser considerados: (1) homogêneos ou (2) heterogêneos, considerando suas capacidades em relação aos sensores externos de detecção, ou seja, o erro introduzido na suas medidas de distância relativa (considerando que não há falhas na identificação dos robôs). No caso de robôs homogêneos, pode-se eliminar uma direção qualquer da aresta bidirecional; no caso de robôs heterogêneos, mantém-se a direção apontando para o robô menos acurado, ou seja, a leitura do sensor mais acurado é usada para atualizar as crenças de posturas dos robôs.

Como visto no Capítulo 4, a atualização das crenças das posturas dos robôs em um grupo é dada por uma distribuição conjunta. Para um grupo de $M$ robôs tem-se:

$$
p\left(\mathbf{x}_{t}^{1}, \mathbf{x}_{t}^{2}, \cdots, \mathbf{x}_{t}^{M} \mid d\right)=p\left(\mathbf{x}_{t}^{1} \mid \mathbf{x}_{t}^{2}, \cdots, \mathbf{x}_{t}^{M}, d\right) \cdot p\left(\mathbf{x}_{t}^{2} \mid \mathbf{x}_{t}^{3}, \cdots, \mathbf{x}_{t}^{M}, d\right) \cdot \cdots \cdot p\left(\mathbf{x}_{t}^{M} \mid d\right),
$$

onde $d$ é toda informação obtida pelos robôs, que inclui as observações do ambiente, medidas do movimento e detecções.

Por razões computacionais, uma vez que é muito custoso calcular a distribuição de probabilidade conjunta, o que é implementado de fato é uma aproximação desta distribuição, baseada na representação fatorada que considera que a distribuição conjunta é igual ao produto das distribuições marginais:

$$
p\left(\mathbf{x}_{t}^{1}, \mathbf{x}_{t}^{2}, \cdots, \mathbf{x}_{t}^{n} \mid d\right)=p\left(\mathbf{x}_{t}^{1} \mid d\right) \cdot p\left(\mathbf{x}_{t}^{2} \mid d\right) . \cdots \cdot p\left(\mathbf{x}_{t}^{M} \mid d\right) .
$$




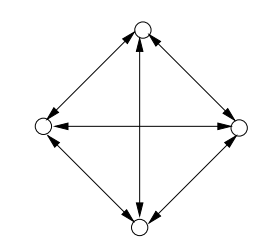

Figura 5.7: Grafo representando a situação em que todos os quatro robôs detectam e são detectados uns pelos outros.

Da mesma forma que na atualização de posturas no caso da detecção entre dois robôs, a multidetecção também é considerada uma aproximação da distribuição conjunta, na forma de uma representação fatorada. No entanto, como um caso de multidetecção envolve vários robôs, podendo no pior dos casos ser representado por um grafo completo, é necessário alguma forma de reduzir a quantidade de comunicação entre os robôs, a fim de reduzir custos computacionais e de processamento.

Para realizar a atualização das posturas no caso da multidetecção, utiliza-se a idéia de que robôs mais certos sobre suas posturas têm mais informação útil para compartilhar, logo, devem comunicar primeiro, propagando seus conhecimentos para o restante do grupo.

Uma medida que pode ser utilizada para estimar a incerteza da crença na postura do robô é o valor de entropia $H$. A entropia mede a quantidade de informação fornecida pela função densidade de probabilidade, e é definida como (RUSSELL; NORVIG, 1995):

$$
H=-\sum_{x} p(\mathbf{x}=x) \log (p(\mathbf{x}=x))
$$

onde $p(\mathbf{x}=x)$ denota a crença do robô estar localizado na postura $x$. O valor de entropia $H$ é zero se o robô está perfeitamente localizado em uma determinada postura, e o valor de entropia alcança um valor máximo se o robô está totalmente incerto sobre sua postura, o que significa que a função densidade de probabilidade é uniformemente distribuída.

A informação obtida pelo encontro de dois robôs é dada pelo valor mínimo da entropia entre os robôs, $H_{i j}=\min \left(H_{i}, H_{j}\right)$, onde $H_{i j}$ representa o valor de entropia do encontro dos robôs $R_{i}$ e $R_{j}$. Neste caso, para um grafo unidirecional $G=(V, E)$, todas as arestas $\left(R_{i}, R_{j}\right) \in E$ são rotuladas com um valor ponderado que corresponde à entropia $H_{i j}$.

Dado um grafo bidirecional ponderado $G$, o problema de multidetecção pode ser formulado como: separar o grafo em componentes conexos $C_{j}$, para $j=$ $1, \cdots, N_{c}$, onde $N_{c}$ é o número de componentes conexos; encontrar, para cada 
componente $C_{j}$, um subconjunto de arestas $E_{C_{j}}^{\prime}$ a partir de $E_{C_{j}}$, de uma maneira que todos os vértices de $V_{C_{j}}$ sejam incidentes nas arestas em $E_{C_{j}}^{\prime}$, resultando em um novo componente $C_{j}^{\prime}=\left(V_{C_{j}}, E_{C_{j}}^{\prime}\right)$ com peso total mínimo.

Em qualquer momento é possível representar uma configuração de deteç̧ão dos robôs por um grafo $G=(V, E)$ e encontrar os componentes conexos $C_{j}$, para $j=1 \cdots, N_{c}$, onde $V=\cup V_{C_{j}}, E=\cup E_{C_{j}}$ e $E_{C_{j}} \neq \emptyset$. Para cada $C_{j}$, os seguintes passos devem ser seguidos para atualizar as crenças de postura dos robôs:

1. Reduzir toda aresta bidirecional para aresta unidirecional, apontando para o robô com medidas sensoriais de distância menos acuradas.

2. Atribuir um peso $H_{i j}$ para cada aresta $\left(R_{i}, R_{j}\right)$.

3. Encontrar um subconjunto de arestas $E_{C_{j}}^{\prime} \subseteq E_{C_{j}}$, tal que $C_{j}^{\prime}=\left(V_{C_{j}}, E_{C_{j}}^{\prime}\right)$ tenha peso mínimo.

4. Ordenar as arestas $\left(R_{i}, R_{j}\right) \subseteq E_{C_{j}}^{\prime}$ por ordem crescente dos pesos $H_{i j}$.

5. Atualizar as crenças das posturas dos robôs seguindo a ordenação das arestas de $E_{C_{j}}^{\prime}$.

Como um exemplo, considere a configuração mostrada na Figura 5.8(a), representada pelo grafo:

$$
G=(\{R 1, R 2, R 3, R 4, R 5\},\{(R 1, R 2),(R 2, R 3),(R 3, R 2),(R 3, R 4))\}),
$$

com $R 2$ com medida de detecção mais acurada que $R 3$; assim, o grafo unidirecional que representa a multidetecção é:

$$
G=(\{R 1, R 2, R 3, R 4, R 5\},\{(R 1, R 2),(R 2, R 3),(R 3, R 4))\}) .
$$

Neste caso, $G$ tem somente um componente conexo:

$$
\left.C_{1}=(\{R 1, R 2, R 3, R 4\},\{(R 1, R 2),(R 2, R 3),(R 3, R 4))\}\right) .
$$

Se forem considerados que os valores de entropia mínimos para as arestas envolvidas na detecção representada por $C_{1}$ são, em ordem, $(R 2, R 3),(R 1, R 2)$ e $(R 3, R 4)$, isto é, $H_{2,3}<H_{1,2}<H_{3,4}$; então, a ordem de atualização deve ser $(R 2, R 3),(R 1, R 2)$ e $(R 3, R 4)$. Desta forma, cada par de robôs atualiza suas crenças de posturas seguindo a ordem apresentada na Figura 5.8(b). Agora, suponha que os valores de entropia mínimos sejam, em ordem, $(R 1, R 2),(R 3, R 4)$ e $(R 2, R 3)$, então, a ordem de atualização é $(R 1, R 2)$ e $(R 3, R 4)$, como pode ser 
visto na Figura 5.8(c). Neste caso não é preciso atualizar $(R 2, R 3)$, uma vez que $R 2$ e $R 3$ já foram atualizados na comunicação feita em $(R 1, R 2)$ e $(R 3, R 4)$, respectivamente.

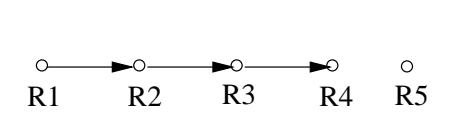

(a)

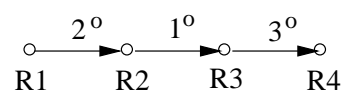

(b)

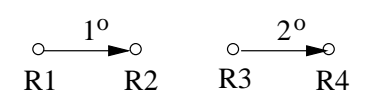

(c)

Figura 5.8: Ordem de atualização das crenças de posturas: (a) Configuração dos robôs (b) $1^{o}:(R 2, R 3), 2^{o}:(R 1, R 2)$, e $3^{o}:(R 3, R 4)$. (b) $1^{o}:(R 1, R 2)$ e $2^{o}$ : $(R 3, R 4)$.

Na localização de multirrobôs cooperativos, quando ocorre uma situação de multidetecção, esta situação é representada por um grafo, em que as arestas correspondem as detecções. Os grafos de seus componentes conexos possuem arestas que representam os casos em que mensagens são trocadas entre os robôs. É necessário que todos os robôs representados nos componentes conexos se comuniquem uns com os outros para encontrar a ordem de atualização. Cada componente conexo, ponderado, unidirecional pode ser construído localmente em cada robô, de uma forma distribuída; para isso, cada robô deve comunicar para os outros mensagens curtas contendo seus valores de entropia, de forma que cada robô pode, independentemente, construir os grafos conexos e ordenar suas arestas.

As contribuições relacionadas ao modelo de multidetecção foram publicadas em (ODAKURA; COSTA, 2006a).

\subsection{Algoritmo de Localização de Markov para Multirrobôs Cooperativos - LMMC}

O algoritmo de LMMC proposto nesta seção realiza a integração dos modelos de observação, modelo de movimento e modelo de detecção positiva, já descritos na literatura, com os modelos propostos nesta tese, a saber: modelo de detecção negativa, modelo de propagação de detecção positiva e modelo de multidetecção.

O algoritmo para LMMC é apresentado no Algoritmo 4. A cada nova informação recebida, a crença de postura é atualizada. O algoritmo recebe dois tipos de informação: local, obtida pelo próprio robô, como observação do ambiente e movimento, e global, comunicada por outros robôs do grupo, quando ocorre detecção ou multideteção. Neste caso, podem ocorrer diversos pares de robôs que, seguindo a ordem determinada, devem atualizar suas estimativas de postura. Para isso, em cada par, um robô assumirá emissor e o outro, o de receptor. 
Para simplificar a notação no algoritmo para LMMC é considerado somente o caso em que o robô $n$ em questão assume o papel de receptor, onde a distância relativa usada é aquela do emissor, $\mathbf{r}_{m}$. No caso do robô $m$ ser o receptor e o robô $n$ ser o emissor a distância relativa a ser usada é $\mathbf{r}_{n}$.

O algoritmo para LMMC, da mesma forma que o Algoritmo 3, é baseado em uma representação fatorada da distribuição de probabilidade, que é uma aproximação da distribuição real. Para que esta aproximação não apresente erros que acumulem com o tempo é necessário garantir que a interação entre os robôs seja fraca (BOYEN; KOLLER, 1999). Isto pode ser alcançado adotando a mesma solução utilizada por Fox (2000), que é bloquear a habilidade de comunicação de um robô que esteve envolvido em uma multidetecção recentemente, até que o mesmo tenha realizado um certo número de atualizações na sua crença de postura.

\subsection{Discussão}

Neste capítulo foi proposta uma abordagem integrada para localização de Markov para multirrobôs cooperativos. Este novo método de localização de multirrobôs cooperativos integra o modelo de detecção positiva de Fox (2000) e o modelo de observação negativa de Hoffmann (2005) com outras informações úteis para atualização das crenças de postura dos robôs, como: detecção negativa, propagação de detecção positiva e multidetecção.

São contribuições deste trabalho as formulações dos modelos de detecção negativa, de propagação de detecção positiva e de multidetecção, além da integração destes modelos com os modelos existentes na literatura para solucionar o problema de localização de multirrobôs cooperativos.

A integração dos modelos foi realizada pela instanciação do modelo de arquitetura descentralizada para localização de multirrobôs descrito no Capítulo 4. Desta forma, cada robô atualiza sua crença de postura localmente, utilizando suas informações locais e as informações comunicadas por outros robôs do grupo.

O algoritmo de localização de Markov foi escolhido para apresentar a instanciação do modelo de arquitetura para localização de multirrobôs por ser um algoritmo clássico na literatura. Além disso, as características de discretização regular do ambiente facilitam o entendimento das técnicas propostas para comunicação.

É sabido que o algoritmo de localização de Markov é computacionalmente muito custoso, sendo impraticável em muitas situações reais. No entanto, o foco 
do trabalho está na localização cooperativa, que se baseia na incorporação de informações compartilhadas para atualização das posturas dos robôs e uma estratégia de comunicação entre os robôs, sendo que toda a modelagem apresentada pode ser implementada em casos reais utilizando algum outro algoritmo de localização menos custoso, como por exemplo, o filtro de partículas. 


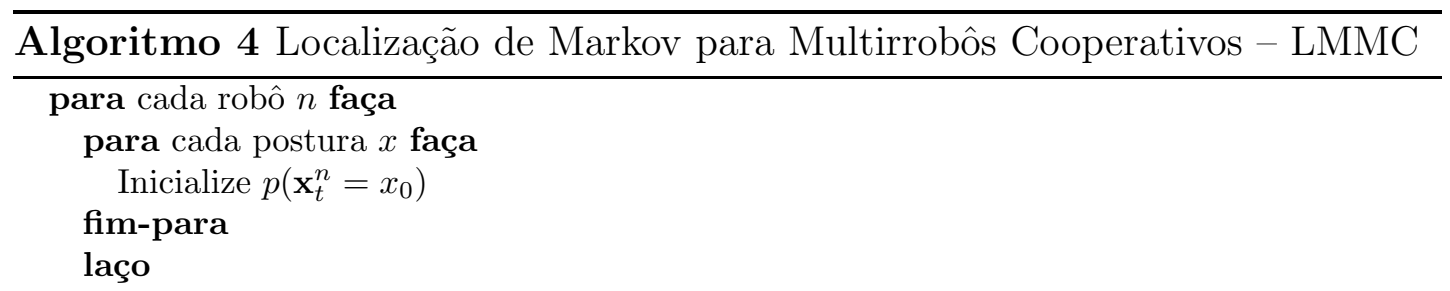

${ }^{*}$ Aplica modelo de movimento*/

se robô efetua uma nova leitura do odômetro $\mathbf{a}_{t}^{n}$ então

para cada postura $x$ faça

$$
p\left(\mathbf{x}_{t}^{n}=x \mid \mathbf{a}_{t}^{n}\right)=\sum_{x^{\prime}} p\left(\mathbf{x}_{t}^{n}=x \mid \mathbf{x}_{t-1}^{n}=x^{\prime}, \mathbf{a}_{t}^{n}\right) p\left(\mathbf{x}_{t-1}^{n}=x^{\prime} \mid d_{t-1}\right)
$$

fim-para

fim-se

/*Aplica modelo de observação*/

se robô efetua uma nova observação positiva do ambiente $\mathbf{o}_{t}^{n}$ então

para cada postura $x$ faça

$$
p\left(\mathbf{x}_{t}^{n}=x \mid \mathbf{o}_{t}^{n}\right)=\frac{p\left(\mathbf{o}_{t}^{n} \mid \mathbf{x}_{t}^{n}=x\right) p\left(\mathbf{x}_{t-1}^{n}=x \mid d_{t-1}\right)}{\sum_{x^{\prime}} p\left(\mathbf{o}_{t}^{n} \mid \mathbf{x}_{t}^{n}=x^{\prime}\right) p\left(\mathbf{x}_{t-1}^{n}=x^{\prime} \mid d_{t-1}\right)}
$$

fim-para

senão se robô efetua uma nova observação negativa do ambiente $\mathbf{o}_{t}^{n-}$ então para cada postura $x$ faça

$$
p\left(\mathbf{x}_{t}^{n}=x \mid \mathbf{o}_{t}^{n-}\right)=\frac{p\left(\mathbf{o}_{t}^{n-} \mid \mathbf{x}_{t}^{n}=x, \mathbf{v}, \mathbf{o b s}\right) p\left(\mathbf{x}_{t-1}^{n}=x \mid d_{t-1}\right)}{\sum_{x^{\prime}} p\left(\mathbf{o}_{t}^{n-} \mid \mathbf{x}_{t}^{n}=x^{\prime}\right) p\left(\mathbf{x}_{t-1}^{n}=x^{\prime} \mid d_{t-1}\right)}
$$

fim-para

fim-se

\section{/*Aplica modelo geral de detecção*/}

se robô está em uma nova detecção ou multidetecção então

para cada par de robôs da detecção na qual $n$ pertence faça

para cada postura $x$ faça

$$
p\left(\mathbf{x}_{t}^{n}=x \mid d_{t}\right)=p\left(\mathbf{x}_{t}^{n}=x \mid d_{t}^{n}\right) \sum_{x^{\prime}} p\left(\mathbf{x}_{t}^{n}=x \mid \mathbf{x}_{t-1}^{m}=x^{\prime}, \mathbf{r}_{t}^{i}\right) p\left(\mathbf{x}_{t-1}^{m}=x^{\prime} \mid d_{t-1}^{m}\right)
$$

\section{fim-para}

\section{fim-para}

\section{fim-se}

se robô $n$ recebe propagação de deteç̧ão positiva então

para cada postura $x$ faça

\section{fim-para}

$$
p\left(\mathbf{x}_{t}^{n}=x \mid \mathbf{x}_{t}^{n_{p}}=x\right)=\frac{p\left(\mathbf{x}_{t}^{n_{p}}=x\right) p\left(\mathbf{x}_{t-1}^{n}=x \mid d_{t-1}^{n}\right)}{\sum_{x^{\prime}} p\left(\mathbf{x}_{t}^{n_{p}}=x^{\prime}\right) p\left(\mathbf{x}_{t-1}^{k}=x^{\prime} \mid d_{t-1}^{k}\right)}
$$

\section{fim-se}

se robô $n$ recebe deteç̧ão negativa enviada pelo robô $m$ então

para cada postura $x$ faça

\section{fim-para}

$$
p\left(\mathbf{x}_{t}^{n}=x \mid \mathbf{x}_{t}^{n-}=x\right)=\frac{p\left(\mathbf{x}_{t}^{n-}=x \mid \mathbf{d}_{t}^{-}\right) p\left(\mathbf{x}_{t-1}^{n}=x \mid d_{t-1}^{n}\right)}{\sum_{x^{\prime}} p\left(\mathbf{x}_{t}^{n-}=x^{\prime} \mid \mathbf{d}_{t}^{-}\right) p\left(\mathbf{x}_{t-1}^{n}=x^{\prime} \mid d_{t-1}^{n}\right)}
$$

fim-se

fim-laço 


\section{Proposta do Modelo para Comunicação}

A cooperação na localização para multirrobôs é alcançada através da comunicação de informações referentes às crenças de posturas dos robôs, determinada pelas situações de detecção. Neste capítulo a comunicação entre os robôs é investigada, contribuindo para um modelo de comunicação adequado para atender as necessidades de compartilhamento de informações do modelo geral de detecção proposto no Capítulo 5.

Na Seção 6.1 é introduzido o assunto de linguagens e protocolos de comunicação. Em seguida, na Seção 6.2, são identificadas as características de comunicação necessárias para utilização do MGD. O protocolo de comunicação derivado desta análise é descrito na Seção 6.3. O MGD possibilita a atualização das crenças das posturas dos robôs com diversas informações ao custo, no entanto, de aumentar a quantidade de informação comunicada quando comparado com o MD. Uma forma de reduzir a quantidade de mensagens trocadas entre os robôs é apresentada na Seção 6.4 e o protocolo de comunicação é adaptado para ser utilizado conjuntamente com esta redução de trocas de mensagens.

\subsection{Linguagens e Protocolos de Comunicação}

Nesta seção são apresentadas algumas questões sobre comunicação em sistemas multiagentes, como forma de melhor caracterizar o modelo de comunicação para localização de robôs. O formalismo para representar a comunicação na teoria de agentes é baseado na teoria de atos de fala de Austin(1962) e Searle(1969) apud (WOOLDRIDGE; JENNINGS, 1995). Na teoria de atos de fala o discurso comunicativo é considerado uma ação, executada pelo locutor com a intenção de mudar o estado do mundo. O locutor pretende causar algum estado mental particular no ouvinte. Assim como as ações, os atos de fala também podem falhar, fazendo com que o locutor não consiga mudar o estado mental do ouvinte. 
Os atos de fala podem ser classificados como:

- Atos locutórios - resultante da ação de se emitir um enunciado.

- Atos ilocutórios - que realiza a ação, como promessa, ordem, pedido, etc.

- Atos perlocutórios - que exerce um efeito sobre o ouvinte, como amedrontar, persuadir, etc.

Em sistemas multiagentes os conteúdos locutórios e ilocutórios são representados explicitamente nas mensagens enviadas (ALVARES; SICHMAN, 1997). De uma maneira mais direta, os atos locutórios são as próprias falas, os atos ilocutórios se relacionam com a intenção do locutor, e os atos perlocutórios correspondem ao resultado desejado pela emissão.

Uma Linguagem de Comunicação de Agentes (LCA) fornece os meios para que os agentes possam trocar mensagens entre si (COHEN; LEVESQUE, 1995; LABROU; FININ; PENG, 1999; CHAIB-DRAA; DIGMUM, 2002). É a linguagem que estabelece qual a sintaxe utilizada para compor as mensagens, que define quais são os campos da mensagem e que estrutura esta deve seguir. Além disso, a LCA define a semântica, o que as informações representam. Em resumo, a LCA associa um significado às mensagens. Duas LCAs bastante conhecidas são Linguagem de Manipulação e Pergunta de Conhecimento (Knowledge Query and Manipulation Language) (KQML) e Fundação para Agentes Físicos Inteligentes - Linguagem de Comunicação de Agentes (Foundation for Intelligent Physical Agents AgentCommunication Language) (FIPA ACL), ambas baseadas na teoria de atos de fala. Nas duas linguagens as mensagens são consideradas como atos de fala cujo objetivo é possibilitar interação entre os agentes, no entanto, diferem na estrutura da sintaxe das mensagens.

A LCA define as mensagens, no entanto a comunicação entre agentes depende da troca de uma seqüência de mensagens, que configura uma conversa, que tem como propósito atingir um objetivo. Para gerenciar as trocas de mensagens em uma conversa utiliza-se um protocolo de comunicação. A utilização de um protocolo de comunicação permite que os agentes estabeleçam objetivos comuns e evitem conflitos.

\subsection{Modelo de Comunicação}

O modelo de comunicação de uma arquitetura para localização de multirrobôs, conforme apresentado no Capítulo 5 e reproduzido novamente na Figura 6.1, 
necessita de algumas modificações para atender o MGD proposto.

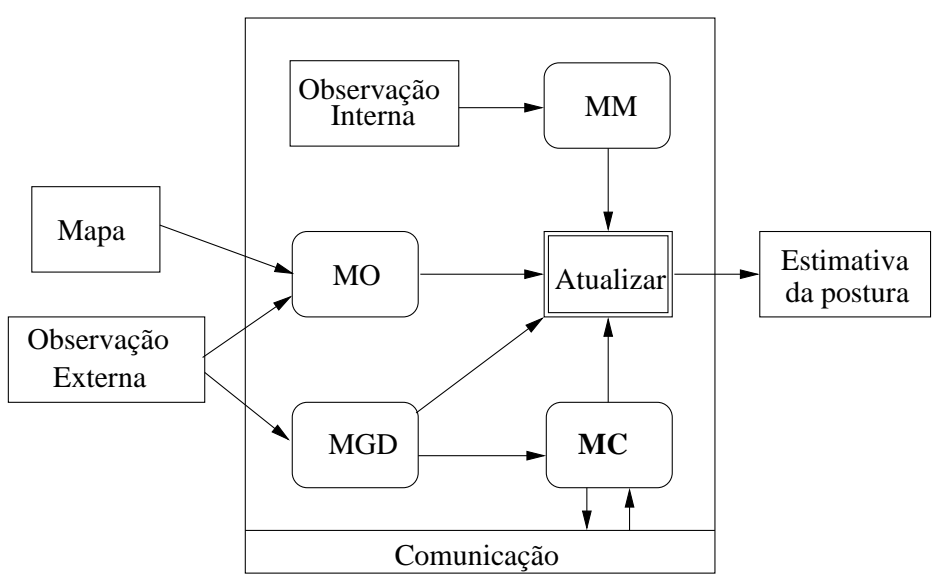

Figura 6.1: Modelo de arquitetura para localização de multirrobôs.

Segundo o MGD proposto no Capítulo 5, as comunicações entre os robôs são guiadas por detecções. Se um robô $n$ detecta um robô $m$, então o robô $n$ comunica para o robô $m$ sua crença de postura e a distância medida entre os dois. O robô $m$ por sua vez comunica para $n$ sua crença de postura. Com estas informações ambos os robôs podem atualizar suas crenças de posturas com a informação de detecção.

Para propagar a informação de detecção positiva, o robô $n$, que efetuou a detecção, comunica a crença dos outros robôs não estarem na região de detecção para todos os robôs que não participaram da detecção.

Se o robô $n$ não detecta nenhum robô, então comunica para os $(M-1)$ robôs, para um grupo de $M$ robôs, a informação de detecção negativa.

Algumas considerações precisam ser feitas sobre a atualização das posturas dos robôs utilizando informações das detecções. Quando uma detecção ocorre, seja esta positiva ou negativa, esta informação refere-se à configuração dos robôs naquele instante de tempo. Para que os robôs atualizem suas posturas com tal informação é necessário que todos os robôs permaneçam parados até que as atualizações devidas sejam realizadas. Esta restrição é bastante importante, uma vez que, sem ela, os robôs atualizariam suas posturas com uma informação inconsistente. Considere o exemplo em que o robô $R 1$ detecta $R 2$. $R 1$ pára e envia para $R 2$ uma mensagem contendo as informações da detecção. O robô $R 2$ deve parar e então atualizar sua crença de postura com a informação comunicada por $R 1$. Se o robô $R 2$ se movimentar antes de atualizar sua crença de postura com a informação de deteç̧ão, este irá atualizar sua crença de postura com uma informação que não corresponde à sua atual postura, mas sim, com a informação de postura comunicada por $R 1$ antes do seu movimento. 
Assim, quando um robô inicia a comunicação para compartilhar informação de detecção positiva, este deve avisar a todos os robôs que participam da detecção que permaneçam parados até que atualizem suas crenças de postura com a informação da detecção. Os robôs que não participam da detecção também devem ser avisados para permanecerem parados até que atualizem suas crenças de postura com a propagação da informação da detecção.

Da mesma maneira, quando um robô obtém informação de detecção negativa, este deve parar e avisar a todos os robôs que fiquem parados até que atualizem suas posturas com a informação da detecção negativa recebida.

Para o caso da multidetecção, os robôs precisam compartilhar informações sobre seus valores de entropia para que possam construir o grafo que representa a multidetecção, na qual estão envolvidos, e então ordenar o conjunto de arestas para definir a seqüência de atualização das posturas dos robôs. Para que isto seja possível, faz-se necessário que cada robô $R_{i}$ que realiza a detecção positiva comunique para todos os outros envolvidos na referida multidetecção seu valor de entropia $H_{i}$ e quais robôs foram detectados.

\subsection{Protocolo de Comunicação}

A configuração dos robôs em um determinado momento pode ser representada por um grafo $G=(V, E)$, em que $V$ é o conjunto de vértices e cada vértice representa um robô do grupo, e $E$ é o conjunto de arestas. Uma aresta ligando dois robôs indica que houve uma detecção entre estes. A direção da aresta aponta para o robô detectado. A situação em que um robô detecta e é detectado ao mesmo tempo é representada por uma aresta bidirecional.

Desta forma, um grafo $G$ pode ser composto por vários componentes conexos $C_{j}$, para $j=1, \cdots, N_{c}$, onde $N_{c}$ é o número de componentes conexos. A Figura 6.2 mostra uma configuração com dois componentes conexos, $C_{1}$ com quatro vértices, e $C_{2}$ com três vértices, onde $C_{1}=(\{5,6,7,8\},\{(5,6),(6,5),(7,6),(6,8)\})$ e $C_{2}=(\{9,10,11\},\{(9,10),(10,9),(10,11)\})$.

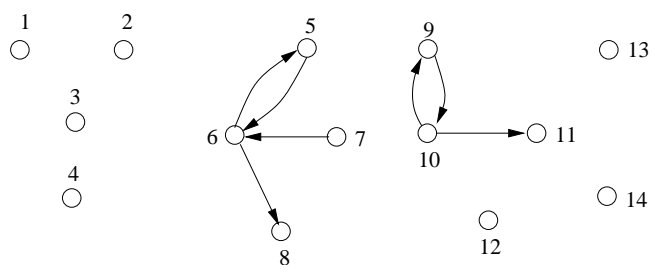

Figura 6.2: Grafo representando a situação em que dois subgrupos de robôs participam de multidetecção. 
As relações de multidetecção podem ser representadas pelos conjuntos $M_{d}^{i}$, que contêm um conjunto de vértices que indica quais robôs foram detectados pelo robô $i$. Para a Figura 6.2 as relações de detecção identificadas são: $M_{d}^{5}=\{6\}$, $M_{d}^{6}=\{5,8\}, M_{d}^{7}=\{6\}, M_{d}^{9}=\{10\}$ e $M_{d}^{10}=\{9,11\}$.

O protocolo de comunicação para localização para multirrobôs cooperativos utilizando o MGD é apresentado na Figura 6.3. Na figura o grupo de robôs é dividido em três subgrupos: no primeiro está o robô $n$ que inicia o processo de comunicação, no segundo estão os robôs que participam das detecções e no terceiro estão os robôs que não participam das detecções. As mensagens trocadas são:

- $\operatorname{stop}()$ : mensagem pedindo para que robô receptor pare.

- $\operatorname{FREE}()$ : mensagem liberando robô receptor para se movimentar.

- DET-SET(): conjunto de detecções do robô emissor, $M_{d}^{e}$, e a acurácia do seu sensor de detecção.

- $\operatorname{BELlef}()$ : crença de postura do robô emissor.

- entropy(): valor de entropia da crença de postura do robô emissor.

- $\operatorname{Propagation}()$ : crença de postura na região de detecção.

- NEGAtive(): crença de postura na região de detecção negativa.

- ACK: mensagem de resposta, significando que o robô receptor de informação de detecção já atualizou sua crença de postura.

O robô $n$ ao receber de seus sensores informação de detecção, seja esta positiva ou negativa, controla inicialmente o processo de comunicação. A primeira mensagem enviada é a de STOP(), para que todos os robôs permaneçam parados durante a fase de troca de mensagens e atualização de posturas. No diagrama são diferenciados os casos de detecção positiva e negativa.

Para o caso da detecção positiva mensagens DET-SET() são trocadas contendo as informações sobre as deteç̧ões que cada robô realizou, $\left(M_{d}^{e}\right)$, juntamente com a medida de acurácia de seu sensor de detecção. Cada robô monta o grafo (direcionado, unidimensional) de detecções. Neste momento é verificado se ocorre uma multidetecção ou se a detecção envolve apenas dois robôs. Esta verificação é necessária pois, se for uma multidetecção, os robôs devem encontrar a ordem de atualização das posturas baseada na redução e ordenação das arestas do grafo. 
A regra que estabelece o critério de decisão para definir se é uma multidetecção ou não, para cada componente conexo $C_{j}=\left(V_{C_{j}}, E_{C_{j}}\right)$, é:

$$
\text { É uma multidetecção se }\left\{\begin{array}{l}
\left|E_{C_{j}}\right| \geq\left|V_{C_{j}}\right| \text { para }\left|V_{C_{j}}\right|=3 \text { ou, } \\
\left|E_{C_{j}}\right|+1 \geq\left|V_{C_{j}}\right| \text { para }\left|V_{C_{j}}\right|>3
\end{array}\right.
$$

Caso contrário, não é uma multidetecção.

Para encontrar a ordem de atualização das posturas no caso em que a multidetecção foi confirmada, os robôs precisam trocar mensagens com seus valores de entropia da sua crença de postura, ENTROPY(). Neste momento, os robôs podem trocar suas crenças de postura, BELIEF(), na ordem estabelecida, para realizarem as atualizações.

No caso do critério de decisão pela multidetecção não ser atendido, os robôs podem trocar mensagens do tipo BELIEF(), na ordem estabelecida, para efetuarem suas atualizações de crenças de posturas, não sendo necessário comunicar seus valores de entropia.

O primeiro robô na ordem estabelecida de comunicação assume o controle da comunicação (robô $n$ ). Ao término das atualizações, os robôs receptores de informação que estão diretamente envolvidos na detecção positiva enviam uma mensagem ACK para o robô de controle.

Ao fim das atualizações com a detecção positiva, o robô de controle $n$ pode propagar a informação de detecção para os robôs que não participaram da detecção através da mensagem PropAGATION(), para que atualizem suas crenças de postura. O término da atualização é comunicado com ACK para o robô de controle.

Para o caso da detecção negativa, o robô que efetuou leitura de seus sensores de detecção envia para os robôs não detectados a mensagem NEGATIVE(). Os robôs atualizam suas crenças de postura e indicam com ACK que terminaram.

Após as atualizações das posturas, o robô $n$ de controle manda uma mensagem FREE(), liberando o grupo de robôs.

\subsection{Reduzindo Comunicação}

A comunicação entre robôs, no caso da localização, pode ser vista como uma maneira de aumentar a percepção do robô sobre seu estado no mundo. Desta forma, a estimativa de postura do robô pode ser obtida tanto das observações 
locais do ambiente, como das observações dos outros robôs, obtidas através de comunicação. Assim, como o objetivo da comunicação para localização de robôs móveis consiste em contribuir para uma estimativa de postura mais acurada, é possível utilizar uma redução de comunicação para obter a desejada qualidade de estimativa de postura concomitantemente a uma diminuição da quantidade de informação comunicada e do tempo de processamento das crenças de posturas dos robôs.

Cada vez que uma mensagem é trocada entre robôs, utiliza-se recursos de comunicação e de processamento. Este último refere-se à tarefa de atualizar a postura do robô com a nova informação recebida. Desta forma, independentemente da escolha da linguagem e do protocolo de comunicação, é útil implementar maneiras para uma redução de comunicação, que se preocupam com o quê, quando e pra quem comunicar.

O quê comunicar é o campo de conteúdo da mensagem. Para quem comunicar é determinado pelos protocolos de comunicação, ou seja, para cada caso de nova evidência, detecção positiva, negativa ou propagação, as mensagens são trocadas entre os envolvidos nesses acontecimentos. Resta responder à pergunta de quando comunicar.

Uma primeira resposta para a pergunta de quando comunicar é que a comunicação pode acontecer toda vez que uma nova evidência estiver disponível, isto é, toda vez que o modelo de detecção receber uma observação externa, diferente da anterior, seja esta uma detecção positiva ou negativa. Suponha a situação em que todos os robôs estão parados; logo, não terão uma modificação da sua crença de postura dada por um movimento ou pela percepção de um marco no ambiente ou mesmo uma nova detecção. Logo, nenhum dos robôs tem algo novo para compartilhar. No entanto, considere a situação onde dois robôs estão totalmente perdidos e trocam mensagens que não ajudam o outro a se localizar, ou ainda, quando dois robôs estão bem localizados e trocam mensagens dizendo onde estão. Em nenhum desses casos a comunicação ajuda a melhorar as estimativas de posturas dos robôs, sendo a troca de mensagens um desperdício de recursos de comunicação e de processamento de informação.

Para evitar estas situações em que uma informação sem utilidade é comunicada, pode-se utilizar uma função utilidade que avalia a utilidade da informação comunicada antes de ser enviada. Assim, cada robô, antes de iniciar um processo de troca de mensagens, aplica a função utilidade para medir se a informação a ser enviada pode ser útil ou não. 
De maneira análoga, o robô que recebe uma mensagem pode avaliar se a informação recebida é útil ou não, ou seja, se é interessante atualizar sua crença de postura utilizando a informação recebida. No caso da informação não ser útil, o robô que recebeu a mensagem economiza o processamento da informação que não vai trazer melhora na sua estimativa de postura. Além disso, se a informação recebida não for avaliada como útil, o robô que recebeu a mensagem não prossegue com a troca de mensagens, evitando trocas de mensagens desnecessárias.

A função utilidade pode ser definida em termos da certeza na estimativa da postura. Um robô que sabe onde está pode ter informações úteis para compartilhar com um robô que não o sabe, e da mesma forma, um robô que está totalmente incerto sobre sua postura não pode ajudar outro.

Assim, uma redução de comunicação pode ser obtida em termos da função utilidade. A comunicação entre robôs acontece quando o robô que inicia a troca de mensagens tem informação útil para compartilhar e a troca só continua se o robô que recebe as informações considera que recebeu uma informação útil.

Considere dois robôs $A$ e $B$, a utilidade de suas crenças de posturas dadas por $U_{A}$ e $U_{B}$, e ainda, seus limiares de utilidade dados por $L_{U_{A}}$ e $L_{U_{B}}$, respectivamente.

Se o robô $A$ assume o papel de emissor, ou seja, tem uma nova evidência e deseja compartilhar com outro robô, então:

- Se $U_{A} \geq L_{U_{A}}$ então o robô $A$ envia uma mensagem.

Se o robô $B$ recebe uma mensagem do robô $A$, ou seja, assume o papel de receptor, então:

- Se $U_{A} \geq L_{U_{B}}$ então o robô $B$ processa a informação recebida, e

- Se $U_{B} \geq L_{U_{B}}$ então o robô $B$ envia uma resposta para o robô $A$.

Desta forma, definindo qual a função utilidade e quais são os limiares empregados, é possível utilizar a redução de comunicação proposta, que restringe as trocas de mensagens entre robôs, possibilitando que a comunicação ocorra apenas quando houver informação útil para ser compartilhada.

Esta redução de comunicação pode ser utilizada em conjunto com a localização para multirrobôs cooperativos como forma de restringir a quantidade de comunicação realizada pelos robôs, sem, no entanto, permitir que ocorra uma diminuição significativa na acurácia dos resultados da localização. 
A utilidade da informação pode ser definida por $H$, que é o valor de entropia da crença de postura de um robô. O valor de entropia se aproxima de zero quando o robô está certo de sua postura e atinge valor máximo quando o robô está totalmente incerto sobre sua postura. Se um robô possui alguma informação para comunicar para os outros robôs do grupo, este primeiro verifica se $H_{e} \leq L$, para então começar a comunicação, onde $H_{e}$ é o valor de entropia do robô emissor e $L$ é o limiar de emissão. O robô que recebe uma mensagem de um emissor exerce o papel de receptor, e aceita a informação recebida se $H_{r} \geq H_{e}$, onde $H_{r}$ é o valor de entropia do robô receptor $r$.

A redução de comunicação é totalmente descentralizada, uma vez que cada robô depende apenas de sua crença de postura para decidir sua participação em uma comunicação ou não.

A redução de comunicação pode ser empregada em diferentes situações na localização de multirrobôs cooperativos: detecção positiva ou negativa, propagação de detecção positiva e multidetecção, com o objetivo de reduzir a quantidade de mensagens transmitidas, definindo condições para as trocas de mensagens e, como conseqüência, reduzindo a quantidade de computação dos robôs na tarefa de atualização de suas crenças de postura.

Na localização de multirrobôs cooperativos, quando ocorre uma multidetecção, esta situação é representada por um grafo $G=(V, E)$, composto de componentes conexos, $C_{j}$. Após redução e ordenação das arestas por peso, temse novos componentes $C_{j}^{\prime}=\left(V_{C_{j}}, E_{C_{j}}^{\prime}\right)$, que formam o grafo $G^{\prime}=\left(V, E^{\prime}\right)$. As arestas $E^{\prime}$ correspondem às detecções entre pares de robôs, e a ordem de $E^{\prime}$ define a ordem em que as atualizações das crenças de postura dos robôs devem acontecer.

Neste momento, a redução de comunicação pode ser empregada, verificando para cada par de robôs ligados por uma aresta de $E^{\prime}$, a utilidade ou não da comunicação entre eles, e restringindo a comunicação quando esta não for útil para melhorar as estimativas de postura dos robôs.

O protocolo de comunicação proposto pode ser adaptado para incorporar estas reduções na quantidade de mensagens comunicadas. O novo protocolo de comunicação é apresentado na Figura 6.4. A principal diferença entre esta versão e a anterior está na adição de uma mensagem com o valor de entropia, ENTROPY() toda vez que uma mensagem com informação de detecção for enviada, seja ela Belief(), propagation() ou negative(). Com o valor de entropia do robô emissor, o robô receptor pode decidir se aceita ou não a informação recebida. 


\begin{tabular}{|c|c|c|}
\hline \hline $\begin{array}{c}\text { Situação de } \\
\text { Comunicação }\end{array}$ & $\begin{array}{c}\text { Robôs } \\
\text { Envolvidos }\end{array}$ & $\begin{array}{c}\text { Condições para } \\
\text { Comunicação }\end{array}$ \\
\hline \hline Detecção única & $M^{\prime}=\{n, m\}$ & se $\left(H_{n} \leq L\right) \mathrm{e}$ \\
$(n$ detecta $m)$ & se $\left(H_{m} \geq H_{n}\right)$ \\
\hline Propagação de & $M^{\prime \prime} \cup\{n\}$ & se $\left(H_{n} \leq L\right) \mathrm{e}$, \\
Deteção & & $k \in M^{\prime \prime}$ e $k \neq n$, \\
de $n$ para $k \in M^{\prime \prime}$ & & se $\left(H_{k} \geq H_{n}\right)$ \\
\hline Deteção & $\left(M-M_{d}^{n}\right)$ & $\operatorname{se}\left(H_{n} \leq L\right) \mathrm{e}$ \\
Negativa & & para todos $k \in\left(M-\left(M_{d}^{n} \cup\{n\}\right)\right)$ \\
de $n$ para $k \in\left(M-\left(M_{d}^{n} \cup\{n\}\right)\right)$ & & se $\left(H_{k} \geq H_{n}\right)$ \\
\hline Multidetecção & $M^{\prime} \operatorname{com}$ & de acordo com ardem dos robôs \\
& $e, r \cup M^{\prime}$ & se $\left(H_{e} \leq L\right) \mathrm{e}$ \\
& & $\left(H_{r} \geq H_{e}\right)$ \\
\hline \hline
\end{tabular}

Tabela 6.1: Condições para redução da comunicação.

A redução de comunicação proposta é resumida na Tabela 6.1. A primeira coluna refere-se às situações de comunicação identificadas, onde a situação de deteç̧ão única é descrita em (FOX, 2000) e envolve um único par de robôs, e somente um robô $(n)$ efetua a deteç̧ão do robô $m$. Toda vez que uma das situações de comunicação ocorrer, a redução de comunicação é utilizada para minimizar a quantidade de mensagens trocadas enquanto obtém o máximo de informação possível. Na situação de multidetecção, $M^{\prime} \subseteq M$ representa um grupo de robôs que detectam uns aos outros simultaneamente, em que $M$ é o número total de robôs no grupo.

Os outros robôs não envolvidos em qualquer tipo de detecção (única, onde os robôs $n$ e $m$ compõem $M^{\prime}$, ou multidetecção, com $\left|M^{\prime}\right|>2$ ) compõem o conjunto $M^{\prime \prime}$, com $M=M^{\prime} \cup M^{\prime \prime}$. Quando ocorre uma propagação de detecção positiva, os robôs de $M^{\prime \prime}$ e o robô de controle $n$ (robô emissor), com $n \in M^{\prime}$, estão envolvidos.

Os robôs detectados pelo robô $n$ compõem o conjunto $M_{d}^{n}$; assim, todos os robôs não detectados por $n$ pertencem ao conjunto $\left(M-M_{d}^{n}\right)^{1}$. Desta forma, em uma situação de detecção negativa, o robô $n$ envia informação para todos robôs $k \in\left((M-\{n\})-M_{d}^{n}\right)$.

Finalmente, na situação de multidetecção, todos $M^{\prime}$ robôs estão envolvidos, como emissores e/ou receptores de informação.

As contribuições relacionadas à redução de comunicação foram aceitas para publicação em (ODAKURA; COSTA, 2007).

\footnotetext{
${ }^{1}$ A operação de subtração de dois conjuntos $X$ e $Y$ é dada por: $X-Y=\{x \mid x \in X$ e $x \notin Y\}$.
} 


\subsection{Considerações Finais}

O modelo de comunicação para localização para multirrobôs cooperativos proposto neste capítulo contempla a integração de informações locais com informações obtidas através da comunicação entre os robôs para atualizar as estimativas de posturas. As informações comunicadas são guiadas por detecções, definidas pelo MGD. São tratadas questões importantes como a coordenação das trocas de mensagens entre os robôs através de um protocolo de comunicação. Além disso, é proposta uma forma de reduzir a quantidade de informação trocada entre os robôs, sendo esta redução de comunicação incorporada ao protocolo de comunicação. 


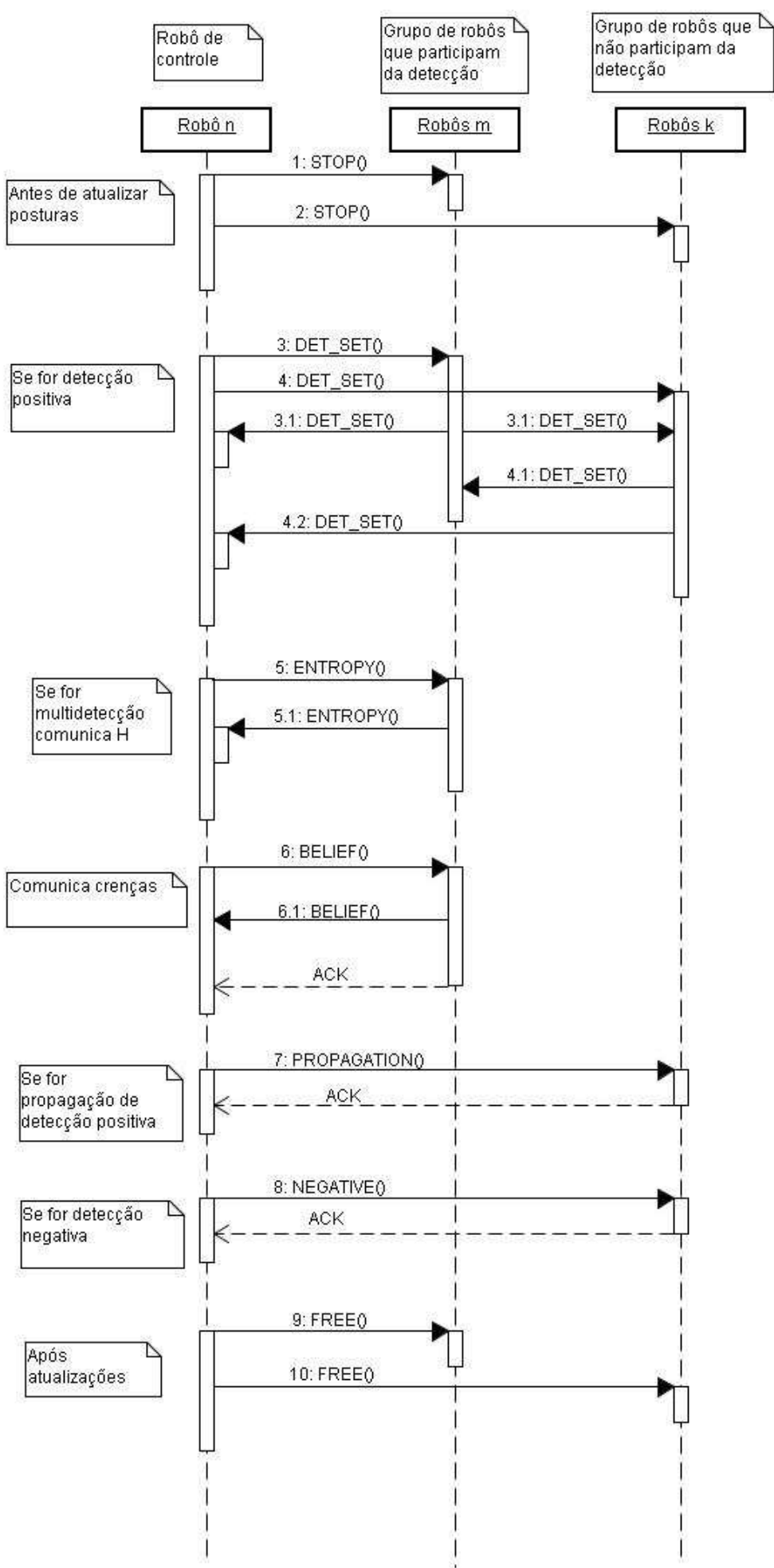

Figura 6.3: Protocolo de comunicação para o modelo geral de deteç̧ão. 


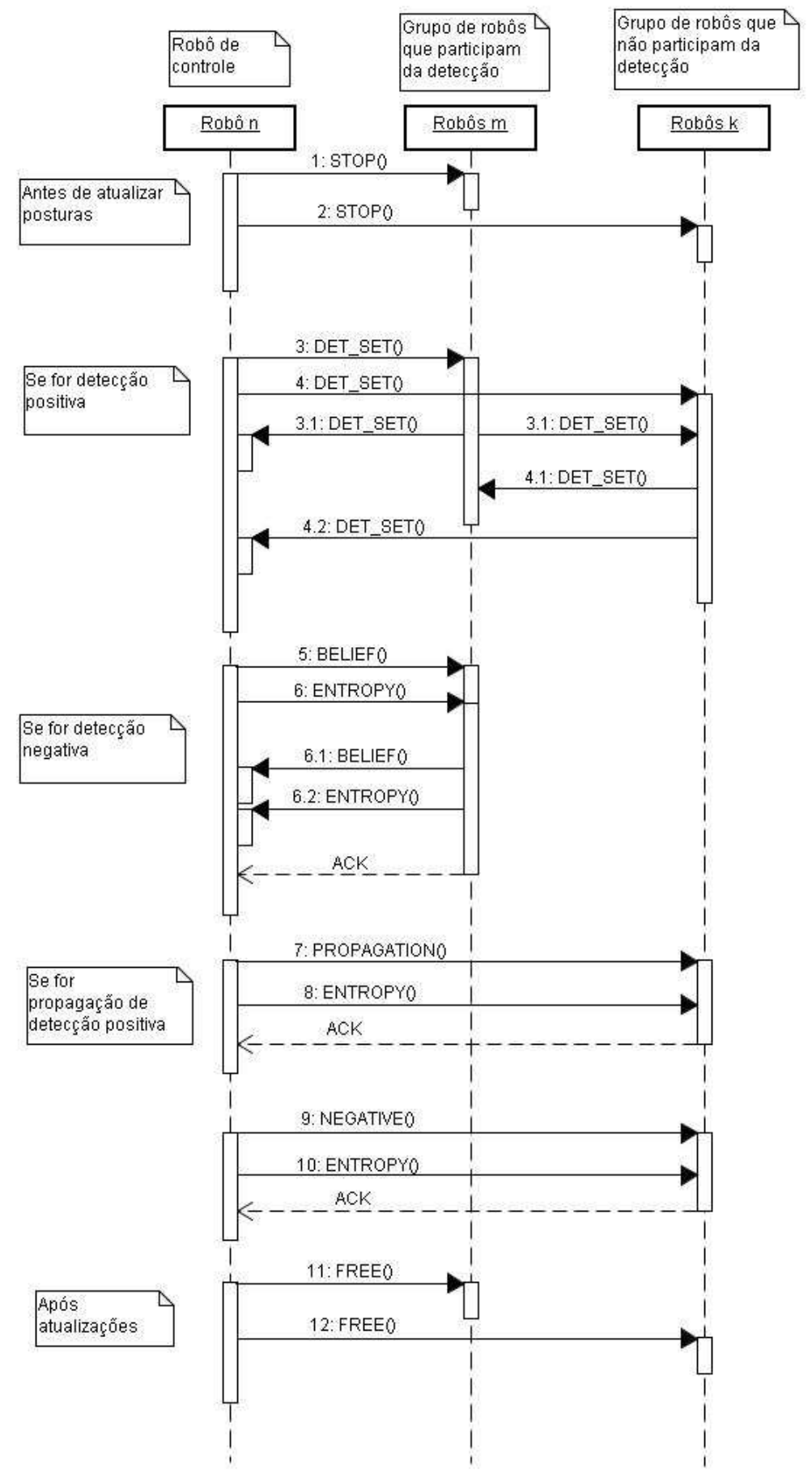

Figura 6.4: Protocolo de comunicação para detecção com redução da comunicação. 


\section{$7 \quad$ Experimentos}

Neste capítulo são apresentados os experimentos realizados utilizando a técnica de LMMC proposta nesta tese. Os resultados experimentais apresentados estão separados em seções. Na Seção 7.1 são apresentados os resultados dos experimentos com a incorporação da detecção negativa na LMM. Na Seção 7.2 são mostrados os resultados obtidos com a utilização da propagação de detecção positiva. Os resultados obtidos ao utilizar a multidetecção são apresentados na Seção 7.3. A integração de todas essas partes, resultando na LMMC, é mostrada na Seção 7.4. A proposta de redução de comunicação nas atualizações das crenças de posturas dos robôs é aplicada na LMMC na Seção 7.5. Por fim, uma discussão sobre os resultados é apresentada.

Os experimentos foram realizados com robôs simulados. Cada robô está equipado com sensor de proximidade para medir as distâncias até as paredes (sensor externo do robô), com alcance de 3 metros. O movimento dos robôs é comandado por velocidade de rotação e translação e medido por um odômetro (sensor interno do robô). Além disso, os robôs possuem um sensor de detecção para identificar outros robôs e medir a distância entre eles, com alcance de 3,5 metros. Todas as medidas sensoriais são corrompidas por erros gaussianos, exceto a identificação dos robôs, que ocorre de forma inequívoca. Todos os robôs possuem um identificador único que é conhecido a priori por todos os robôs do grupo.

O modelo do ambiente também é conhecido a priori, dado por um mapa que representa o ambiente pelos pontos iniciais e finais dos segmentos de retas que correspondem às suas paredes e obstáculos.

O ambiente é dividido em um mapa de grades com células de $0.2 \times 0.2$ metros, e resolução angular de 90 graus. A função distribuição de probabilidade mantém um valor de crença da postura do robô para cada célula da grade, sendo a postura dada pela célula que o robô ocupa e a orientação que apresenta, $(x, y, \theta)$.

Além disso, os robôs estão equipados com dispositivos de comunicação, o que permite que eles troquem mensagens entre si. Os dispositivos de comunicação 
foram implementados livres de erros, transmitindo e recebendo as informações sem corrompê-las.

No início de cada experimento os robôs são distribuídos aleatoriamente pelo ambiente, e se locomovem realizando percursos também aleatórios. O experimento pára quando todos os robôs do grupo tiverem encontrado sua postura no ambiente, ou seja, quando sua crença de postura em uma célula for maior que 0.9 , em uma faixa de 0 a 1.

Os ambientes para testes estão ilustrados na Figura 7.1. O ambiente da Figura 7.1(a) é um ambiente simétrico, com duas salas A e B e um corredor C. O tamanho deste ambiente é de $3 \times 3$ metros. O ambiente da Figura 7.1(b) é um ambiente aberto, com tamanho de $4 \times 4$ metros. Na Figura 7.1(c) é apresentado um ambiente de quatro corredores, nomeados A, B, C e D (o mesmo utilizado em (FOX, 2000)). O ambiente é simétrico, sendo possível apenas que os robôs se localizem ao passar por A ou percorrendo os outros três corredores. Este ambiente possui $6 \times 6$ metros. O ambiente da Figura 7.1(d) apresenta três salas, com tamanho de $8 \times 3.6$ metros. Nas figuras, preto corresponde a obstáculos e branco, área livre.

Todas as implementações, tanto do simulador quanto dos algoritmos de localização utilizados, foram desenvolvidos em $\mathrm{C} / \mathrm{C}++$.

\subsection{Modelo de Detecção Negativa}

Para ilustrar a atualização de postura com informação negativa, pode-se supor a situação em que dois robôs encontram-se no ambiente da Figura 7.1(a). O robô $R 1$ está posicionado na sala $(A)$ e conhece sua postura. O robô $R 2$ está posicionado na sala $(B)$ e sua crença de postura está em dúvida entre a sala $(A)$ e $(B)$. As crenças das posturas dos dois robôs são mostradas nas Figuras 7.2(a) e 7.2(b), respectivamente, onde a quina superior esquerda da sala da Figura 7.1(a) corresponde à coordenada $(0,0)$, da Figura 7.2 , com eixo $x$ na horizontal, da esquerda para a direita, e o eixo y na vertical, de cima para baixo. Note que a dúvida de postura do robô $R 2$ é representada por dois picos em sua distribuição de probabilidade, uma em cada sala. Pela simetria do ambiente, é impossível para $R 2$ determinar, apenas com observações do ambiente, que sua postura real está na sala $(B)$. Ainda, como os robôs estão em salas distintas, um não consegue detectar o outro. No entanto, se o modelo de detecção negativa for utilizado para atualizar a crença de postura, $R 2$ será capaz de se localizar no ambiente. A informação de 


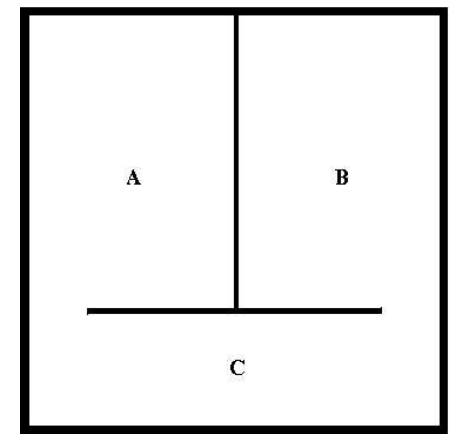

(a)

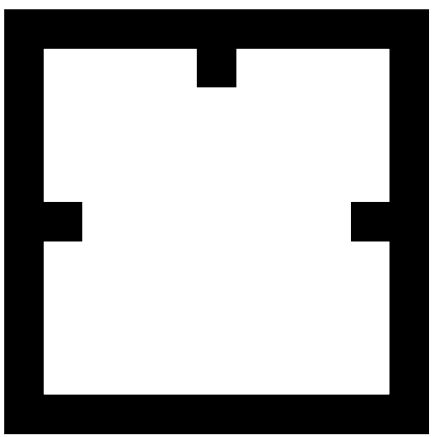

(b)

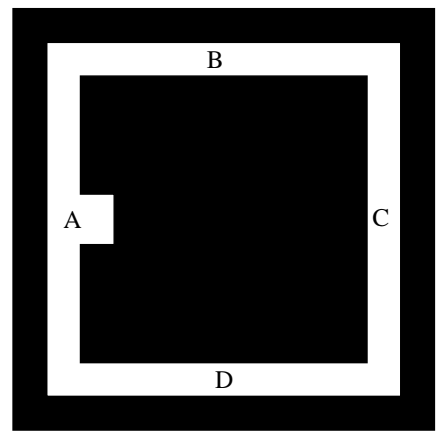

(c)

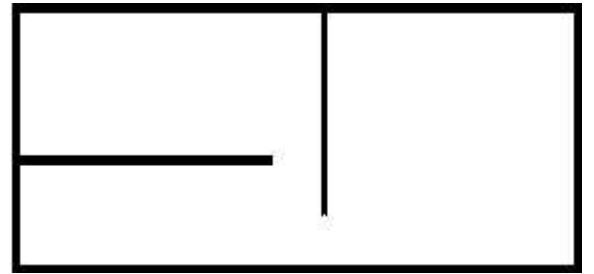

(d)

Figura 7.1: Ambientes de teste: (a) Duas salas simétricas (A e B) e um corredor C. (b) Ambiente aberto. (c) Ambiente de corredores (A, B, C e D). (d) Três salas.

detecção negativa derivada da área de visibilidade de $R 1$ é ilustrada na Figura 7.2(c). Quando $R 2$ atualiza sua crença de postura utilizando a informação de detecção negativa fornecida por $R 1$, este torna-se certo sobre sua postura, como mostra a Figura 7.2(d).

Alguns testes foram realizados com o objetivo de comparar a LMM de Fox (2000) com esta mesma técnica acrescida do modelo de detecção negativa.

O primeiro experimento foi conduzido no ambiente da Figura 7.1(a), com três robôs. O gráfico apresentado na Figura 7.3(a) mostra o erro de localização pelo número de passos. O erro de localização é calculado como sendo a distância euclidiana entre a posição $(x, y)$ real do robô e a posição estimada. Como a crença da postura dos robôs é uma distribuição de probabilidade que mantém um valor de crença de postura para cada célula da grade, utiliza-se como valor de postura estimada a postura com maior valor de probabilidade. O número de passos significa o número de vezes que os robôs atualizaram suas crenças de postura. Isto ocorre toda vez que um movimento, uma observação do ambiente, uma detecção positiva ou uma detecção negativa são utilizados para atualizar a crença de postura. Em cada execução os robôs iniciam a tarefa de localização partindo de posturas iniciais aleatórias. Os valores de erro de localização são valores médios 


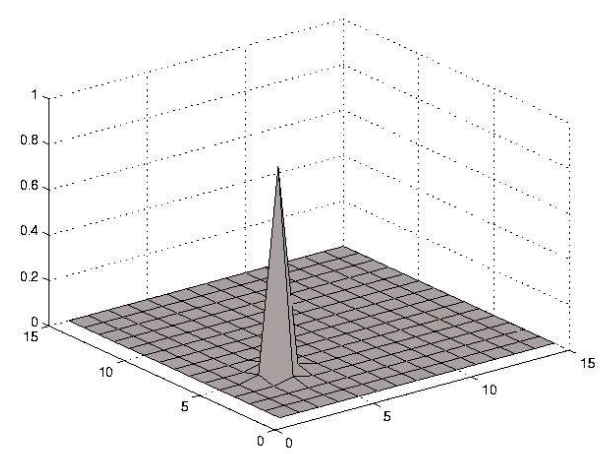

(a)

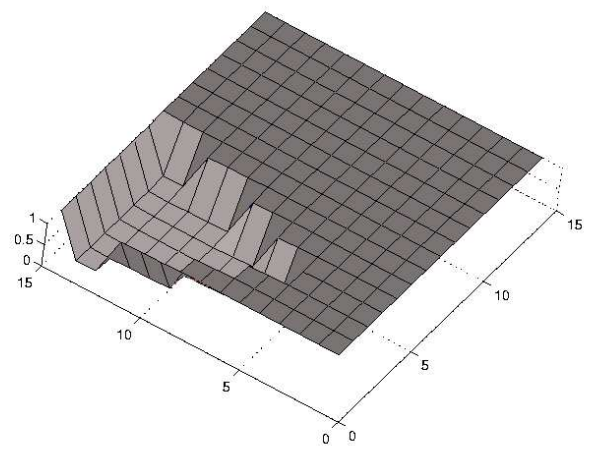

(c)

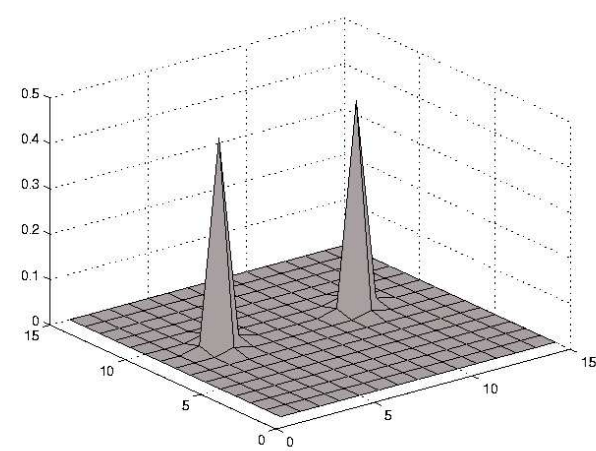

(b)

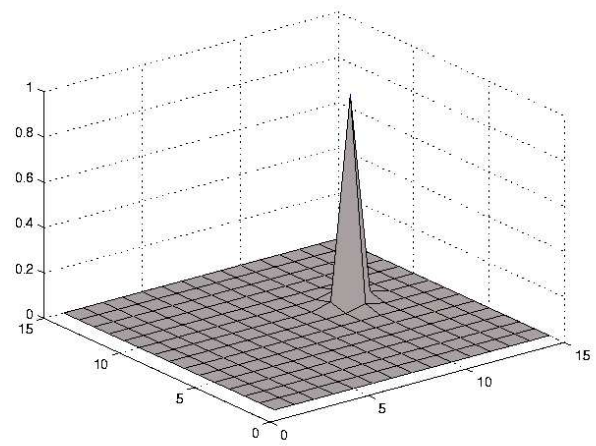

(d)

Figura 7.2: (a) Função densidade de probabilidade do robô R1. (b) Função densidade de probabilidade do robô $R 2$. (c) Informação de detecção negativa comunicada pelo robô $R 1$. (d) Função densidade de probabilidade do robô $R 2$ após incorporar a informação de detecção negativa.

para três robôs em cinco execuções. A utilização do modelo de detecção negativa reduziu os erros de localização quando comparado com a localização apenas com detecções positivas. A partir do passo 25 a localização com detecção negativa determina a postura de todos os robôs, enquanto que a localização apenas com detecção positiva somente o faz passo 45 .

Para avaliar se as técnicas comparadas são significativamente diferentes, isto é, se a incorporação do modelo de detecção negativa na LMM melhora os resultados de localização, foi utilizado o teste $t$ de Student (NEHMZOW, 1999), também conhecido como t-test. Este teste permite verificar se os resultados de duas experiências diferem significativamente. Este teste é bastante utilizado, pois permite decidir se um algoritmo de controle exibe um desempenho melhor que outro.

Para estabelecer se dois valores médios $\mu_{x}$ e $\mu_{y}$ são diferentes, o valor $T$ é 
calculado seguindo a equação:

$$
T=\frac{\mu_{x}-\mu_{y}}{\sqrt{\left(n_{x}-1\right) \sigma_{x}^{2}+\left(n_{y}-1\right) \sigma_{y}^{2}}} \sqrt{\frac{n_{x} n_{y}\left(n_{x}+n_{y}-2\right)}{n_{x}+n_{y}}},
$$

onde $n_{x}$ e $n_{y}$ são os números de pontos, $\mu_{x}$ e $\mu_{y}$ as médias e $\sigma_{x}$ e $\sigma_{y}$ os desvios padrões dos pontos nos experimentos $x$ e $y$.

Se módulo de $T \geq t_{\alpha}$, onde a constante $t_{\alpha}$ define a probabilidade que o teste tem de estar errado, chamado nível de confiança, a hipótese $H_{0}$ de que $\mu_{x}=\mu_{y}$ é rejeitada, significando que os experimentos diferem significativamente. Esta probabilidade é geralmente definida como $5 \%$. O valor de $t_{\alpha}$ depende do número de experimentos e pode ser encontrado na maioria dos livros de estatística.

Outros experimentos foram executados no ambiente da Figura 7.1(b), onde os valores de erro de localização são valores médios para quatro robôs em seis execuções; no ambiente da Figura 7.1(c), onde os valores de erro de localização são valores médios para oito robôs em oito execuções, e no ambiente da Figura 7.1(d), onde os valores de erro de localização são valores médios para dez robôs em quatro execuções.

O teste $t$ de Student foi aplicado para todos os dados experimentais obtidos. Foi calculado o valor do módulo de $T$ para cada passo. O resultado do teste $t$ de Student mostrou que, para experimentos conduzidos nos ambientes das Figuras 7.1(b), 7.1(c) e 7.1(d), não houve uma melhora significativa com o uso da detecção negativa. A razão é que, nestes casos, não ocorrem tantas situações em que um robô está isolado em ambiente ambíguo, de forma a se beneficiar da informação de detecção negativa. No entanto, para o experimento da Figura 7.3(a), o resultado do teste $t$ de Student mostra que as técnicas comparadas são significativamente diferentes, com nível de erro de 15\%, como mostra a Figura 7.3(b).

\subsection{Modelo de Propagação de Detecção Positiva}

A atualização das crenças de posturas dos robôs utilizando propagação da detecção positiva é apresentada nesta seção. É feita a comparação entre a LMM de Fox (2000) com esta mesma técnica acrescida do modelo de propagação de detecção positiva.

Quatro experimentos foram executados e seus resultados são apresentados em gráficos que mostram o erro de localização pelo número de passos. O teste $t$ 


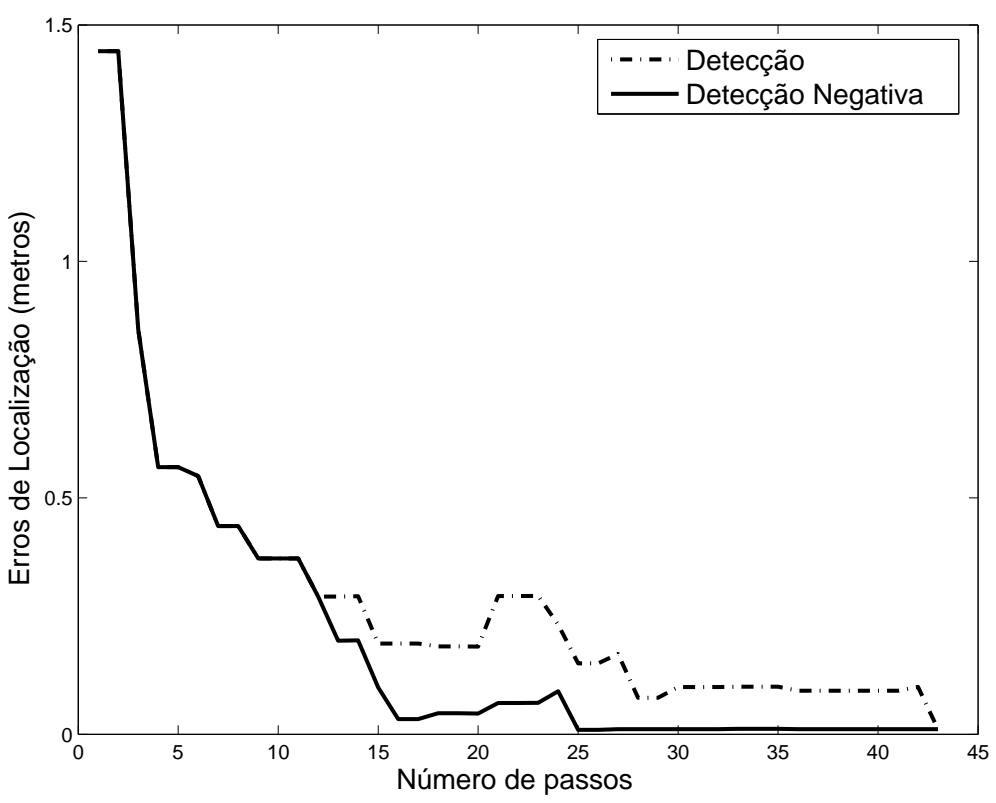

(a)

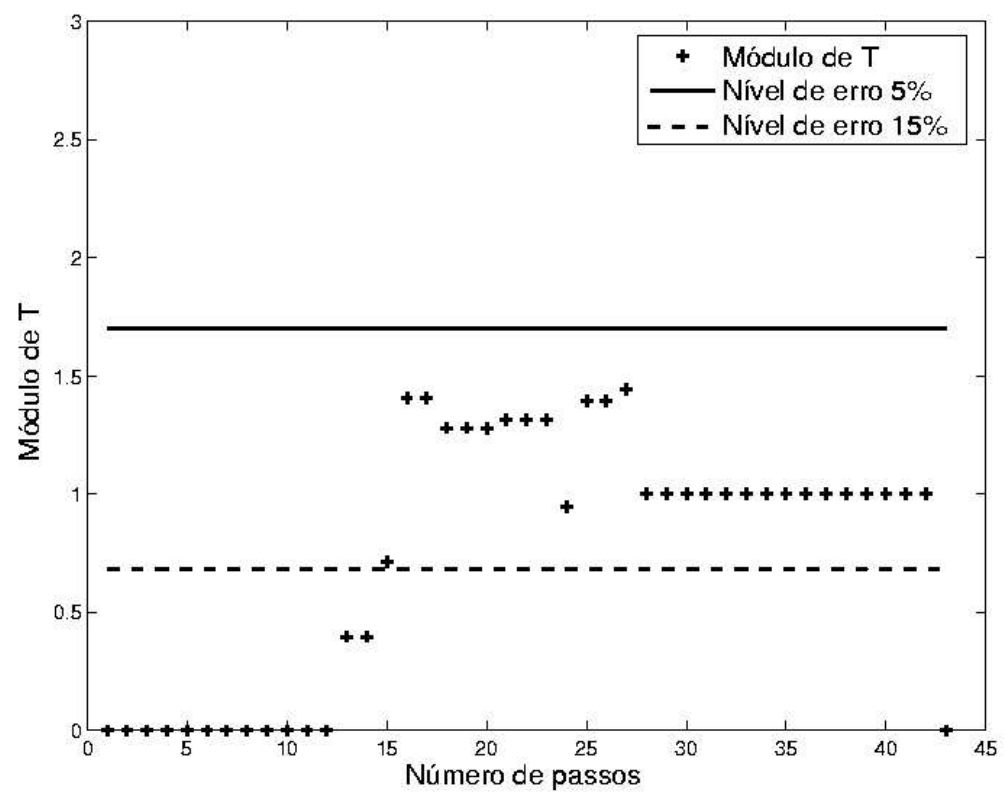

(b)

Figura 7.3: Comparação entre LMM e LMM acrescido do modelo de detecção negativa com três robôs no ambiente simétrico da Figura 7.1(a). (a) Erros de localização. (b) Resultado do teste $t$ de Student. 
de Student foi realizado para os quatro experimentos. Foi calculado o valor do módulo de $T$ para cada passo. A Figura 7.4(a) mostra os resultados do primeiro experimento. Os valores de erro de localização são valores médios para três robôs em cinco execuções no ambiente da Figura 7.1(a). O resultado do teste $t$ de Student para este experimento é apresentado na Figura 7.4(b).

A Figura 7.5(a) mostra os resultados do segundo experimento. Os valores de erro de localização são valores médios para quatro robôs em seis execuções no ambiente da Figura 7.1(b). O resultado do teste $t$ de Student para este experimento é apresentado na Figura 7.5(b).

A Figura 7.6(a) mostra os resultados do terceiro experimento. Os valores de erro de localização são valores médios para oito robôs em oito execuções no ambiente da Figura 7.1(c). O resultado do teste $t$ de Student para este experimento é apresentado na Figura 7.6(b).

A Figura 7.7(a) mostra os resultados do quarto experimento. Os valores de erro de localização são valores médios para dez robôs em quatro execuções no ambiente da Figura 7.1(d). O resultado do teste $t$ de Student para este experimento é apresentado na Figura 7.7(b).

O resultado do teste $t$ de Student mostra que os experimentos das Figuras 7.4(a), 7.6(a) e 7.7(a), são significativamente diferentes, com nível de erro de 15\%. No entanto, os experimentos da Figura 7.5(a) não mostram uma melhora significativa, uma vez que neste ambiente, por ser muito aberto e com um número não muito grande de robôs, há uma quantidade mais reduzida de robôs que se beneficiam com a propagação da detecção positiva, pois a chance de estarem envolvidos na detecção é maior.

\subsection{Modelo de Multidetecção}

A atualização das crenças das posturas dos robôs no caso de multidetecção é investigada nesta seção. Inicialmente são apresentados quatro experimentos comparando a localização com detecção positiva como proposto na LMM por Fox (2000) e a localização com multidetecção. Seus resultados são apresentados em gráficos que mostram o erro de localização pelo número de passos. O teste $t$ de Student foi realizado para todos os experimentos. Foi calculado o valor do módulo de $T$ para cada passo.

O primeiro dos experimentos é apresentado na Figura 7.8(a) que mostra o erro de localização pelo número de passos. Os valores de erro de localização são 


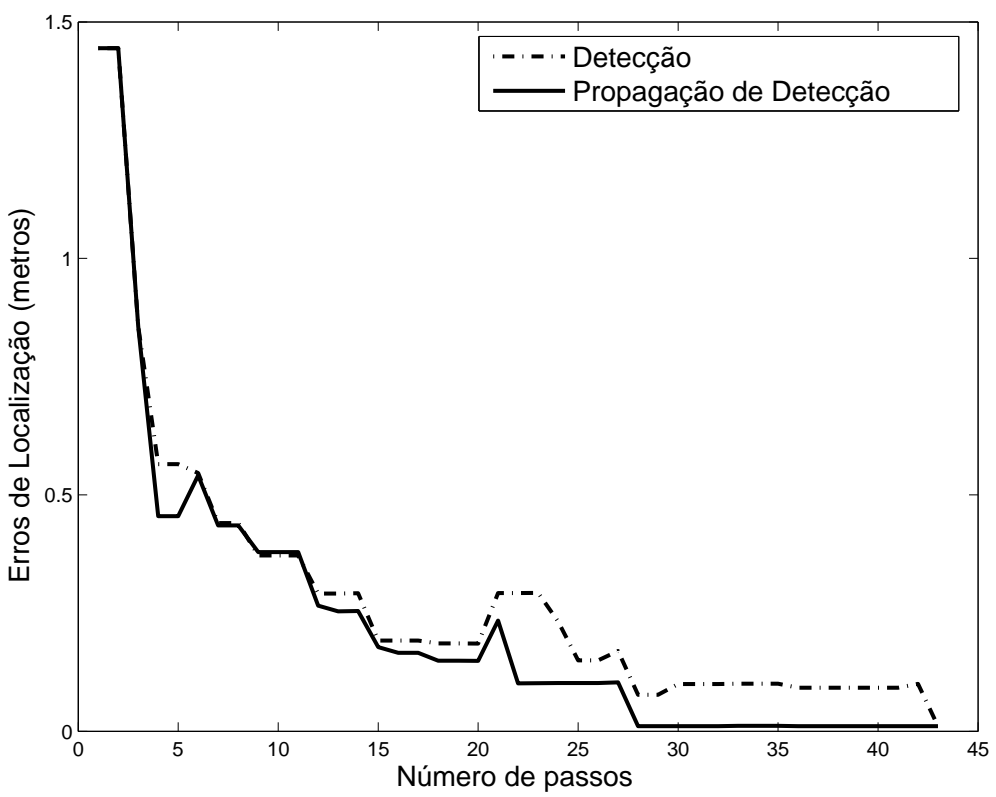

(a)

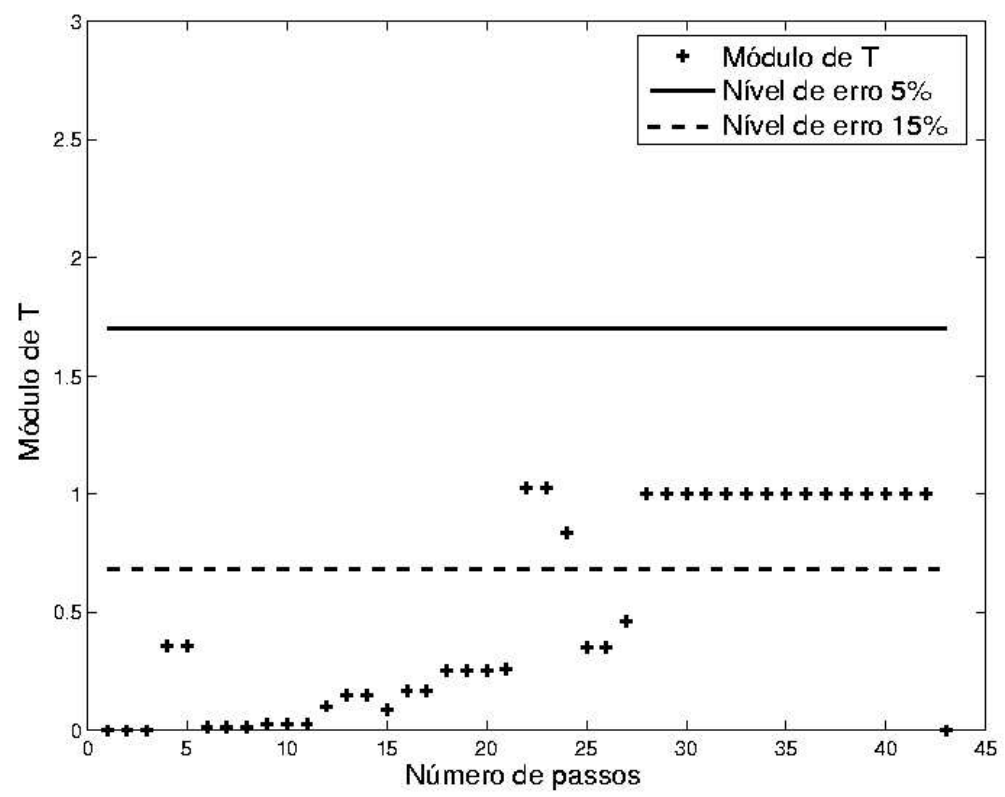

(b)

Figura 7.4: Comparação entre LMM e LMM acrescido do modelo de propagação da detecção positiva com três robôs no ambiente simétrico da Figura 7.1(a). (a) Erros de localização. (b) Resultado do teste $t$ de Student. 


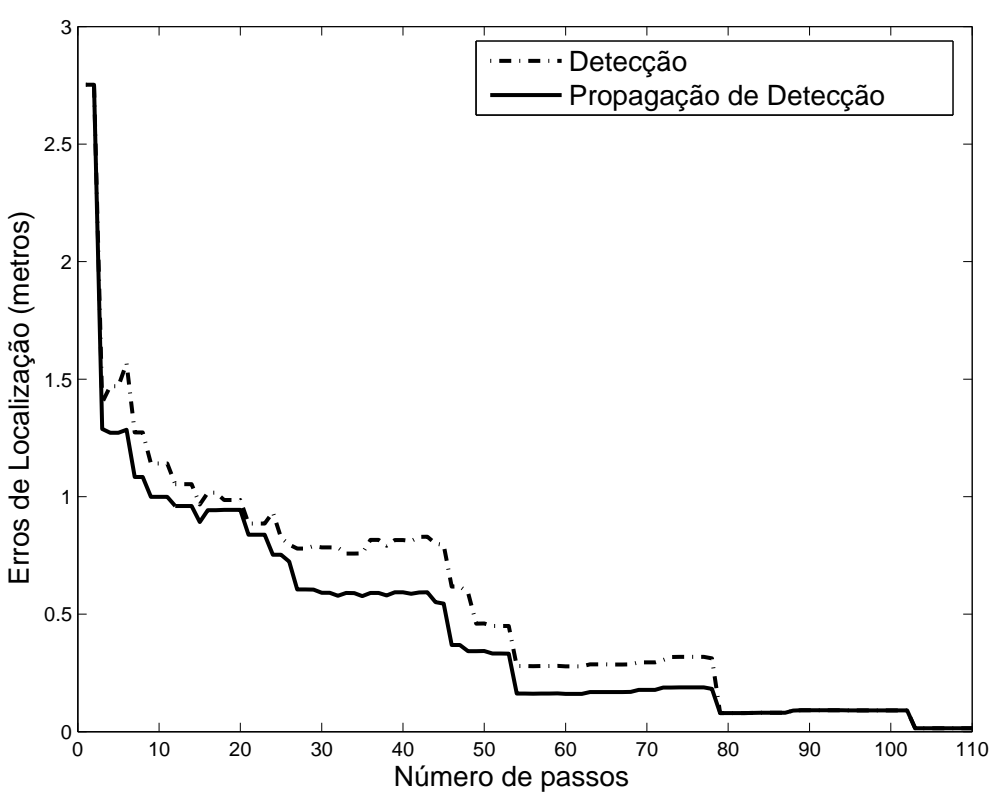

(a)

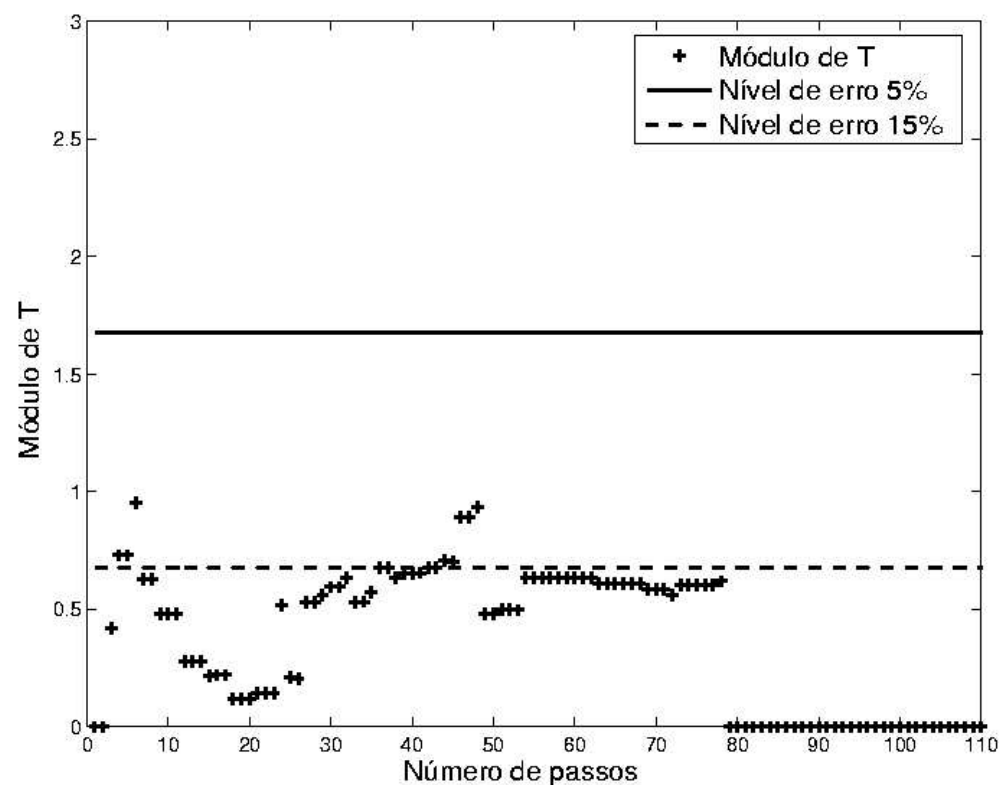

(b)

Figura 7.5: Comparação entre LMM e LMM acrescido do modelo de propagação da detecção positiva com quatro robôs no ambiente aberto da Figura 7.1(b). (a) Erros de localização. (b) Resultado do teste $t$ de Student. 


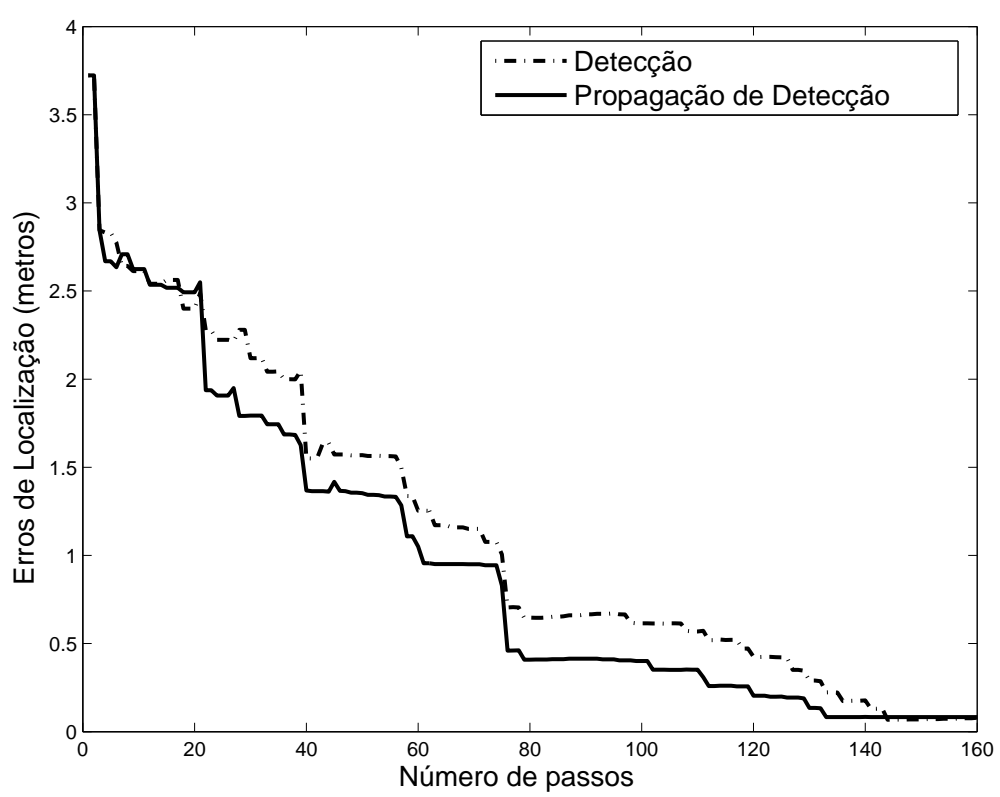

(a)

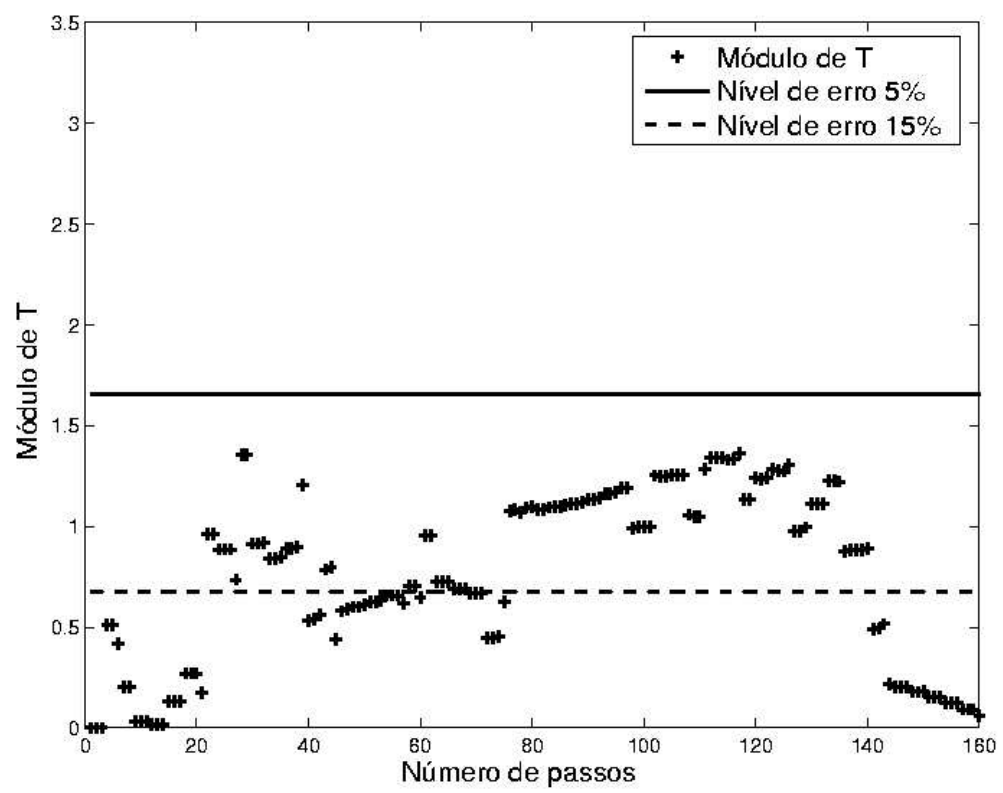

(b)

Figura 7.6: Comparação entre LMM e LMM acrescido do modelo de propagação da detecção positiva com oito robôs no ambiente de corredores da Figura 7.1(c). (a) Erros de localização. (b) Resultado do teste $t$ de Student. 


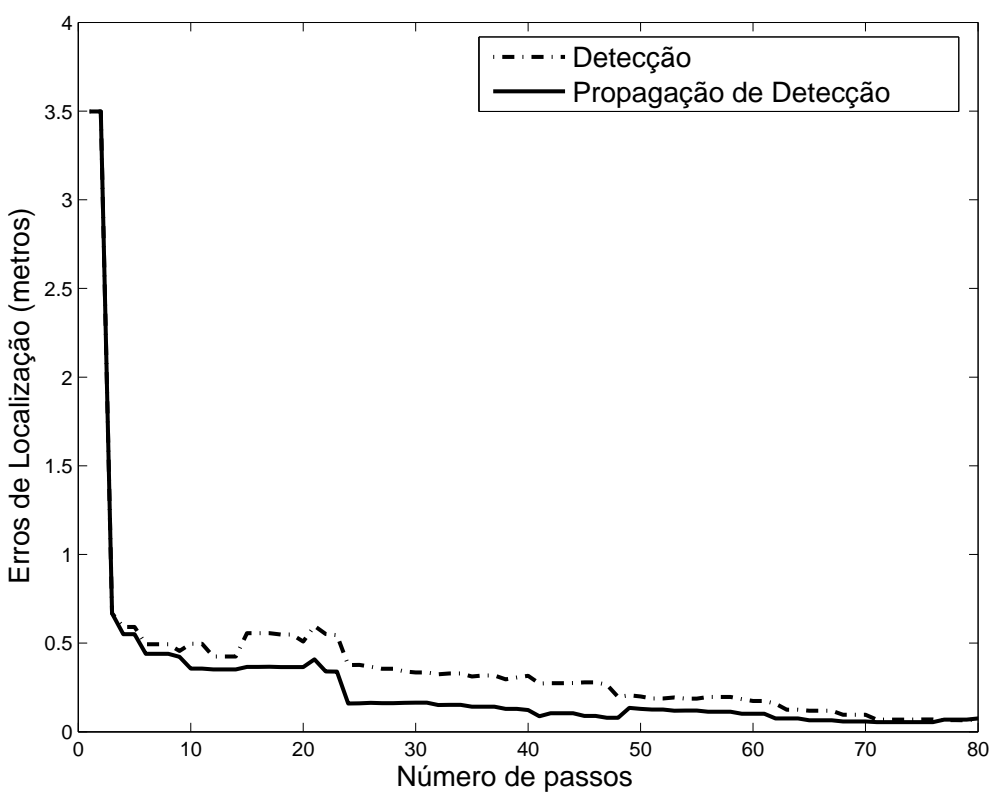

(a)

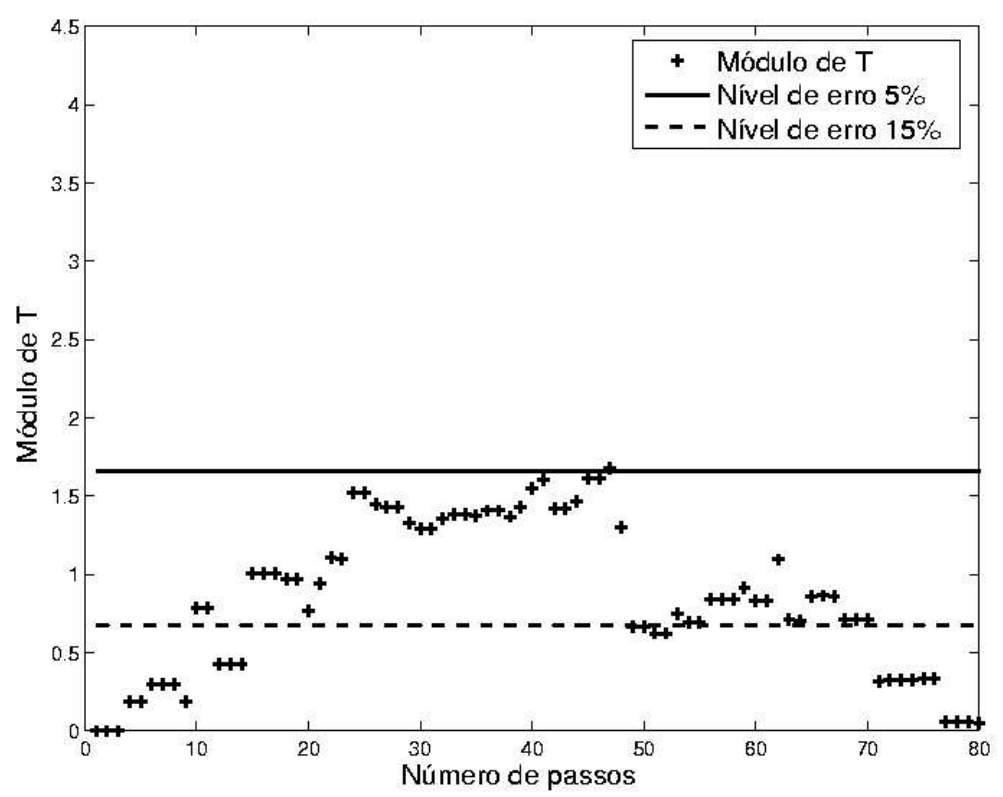

(b)

Figura 7.7: Comparação entre LMM e LMM acrescido do modelo de propagação da detecção positiva com dez robôs no ambiente de salas da Figura

7.1(d) com 10 robôs. (a) Erros de localização. (b) Resultado do teste $t$ de Student. 
valores médios para três robôs em cinco execuções no ambiente da Figura 7.1(a). O resultado do teste $t$ de Student para este experimento é apresentado na Figura $7.8(\mathrm{~b})$.

O segundo dos experimentos, apresentado na Figura 7.9(a), mostra o erro de localização pelo número de passos. Os valores de erro de localização são valores médios para quatro robôs em seis execuções no ambiente da Figura 7.1(b). O resultado do teste $t$ de Student para este experimento é apresentado na Figura $7.9(\mathrm{~b})$.

O terceiro deles é mostrado na Figura 7.10(a), mostra o erro de localização pelo número de passos. Os valores de erro de localização são valores médios para oito robôs em oito execuções no ambiente da Figura 7.1(c). O resultado do teste $t$ de Student para este experimento é apresentado na Figura 7.10(b).

Por fim, na Figura 7.11(a), é mostrado o erro de localização pelo número de passos. Os valores de erro de localização são valores médios para dez robôs em dez execuções no ambiente da Figura 7.1(d). O resultado do teste $t$ de Student para este experimento é apresentado na Figura 7.11(b).

Em todos os casos o erro de localização reduz significativamente ao utilizar a atualização das crenças de posturas considerando os casos de multidetecção quando comparado com a LMM de Fox (2000). No caso da Figura 7.8(a), por exemplo, o erro de localização se aproxima de zero perto do passo 5 para a multidetecção e atinge o mesmo valor para detecção apenas depois do passo 40. O teste $t$ de Student comprova a melhora nas estimativas de postura, como pode ser visto nas Figuras 7.8(b) 7.9(b), 7.10(b) e 7.11(b). Nos dois primeiros experimentos as técnicas comparadas são significativamente diferentes, com nível de erro de $15 \%$ e nos dois últimos, os resultados são significativamente diferentes, com nível de erro de $5 \%$. Isto era esperado, uma vez que nos dois últimos experimentos desta série (7.10(b) e 7.11(b)), um número maior de robôs é utilizado, permitindo a ocorrência de uma maior quantidade de multidetecções.

Um segundo tipo de experimentos foi projetado para comparar a melhor ordem de atualização das crenças de posturas dos robôs. Os casos analisados são: (1) ordem proposta, ordenando as arestas do grafo de multidetecção pelos menores valores de entropia, (2) ordem inversa, ordenando pelos maiores valores de entropia e (3) ordem numérica, onde se considera que os robôs possuem números, e então, a ordem segue o número dos robôs: primeiro robô $R 1$, depois $R 2$ e assim por diante. Os gráficos apresentados nas Figuras 7.12, 7.13, 7.14 e 7.15 mostram o erro de localização pelo número de passos. Para todos os casos, a ordem de 


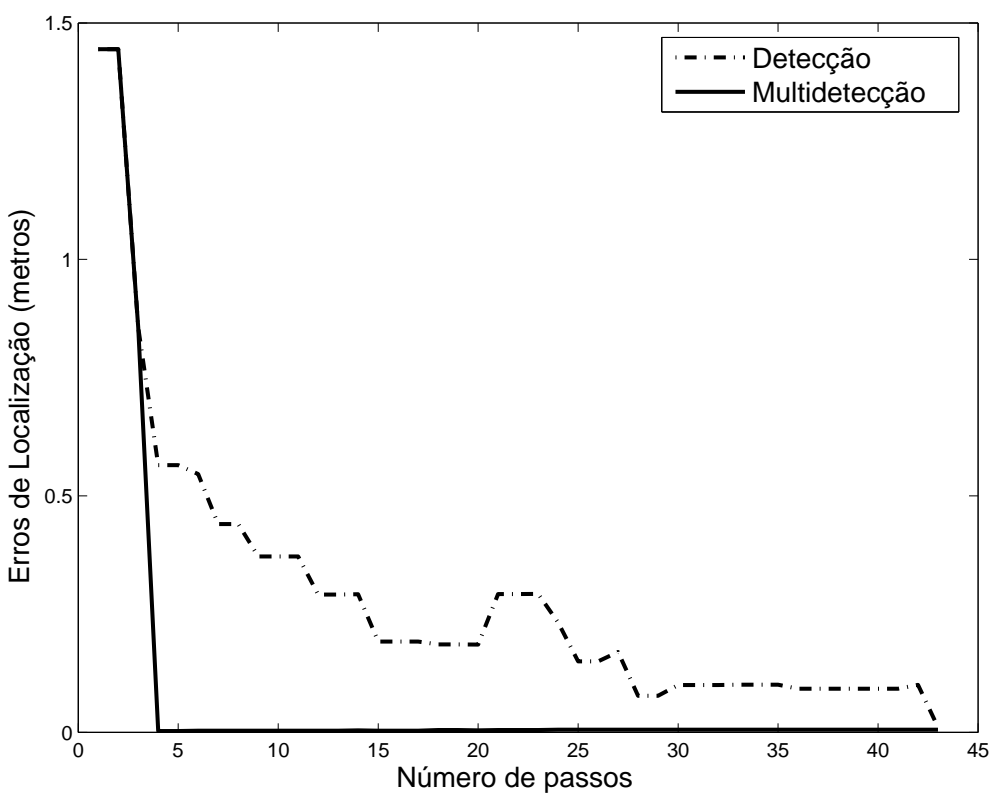

(a)

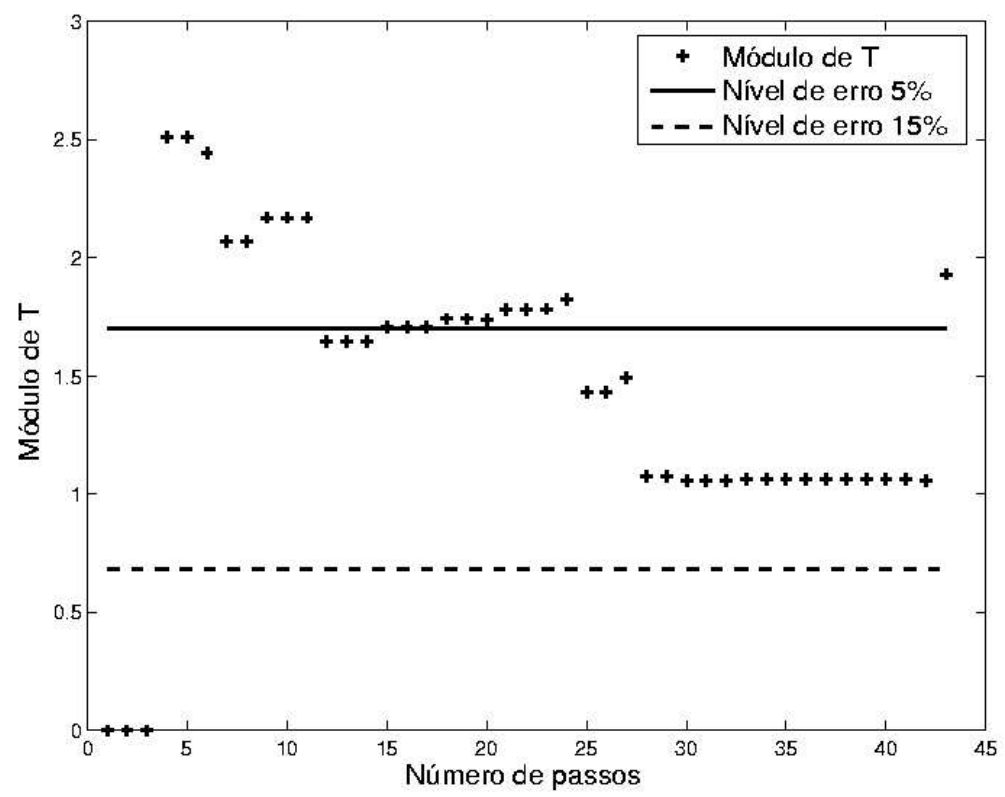

(b)

Figura 7.8: Comparação entre LMM e LMM acrescido do modelo de multidetecção com três robôs no ambiente simétrico da Figura 7.1(a). (a) Erros de localização. (b) Resultado do teste $t$ de Student. 


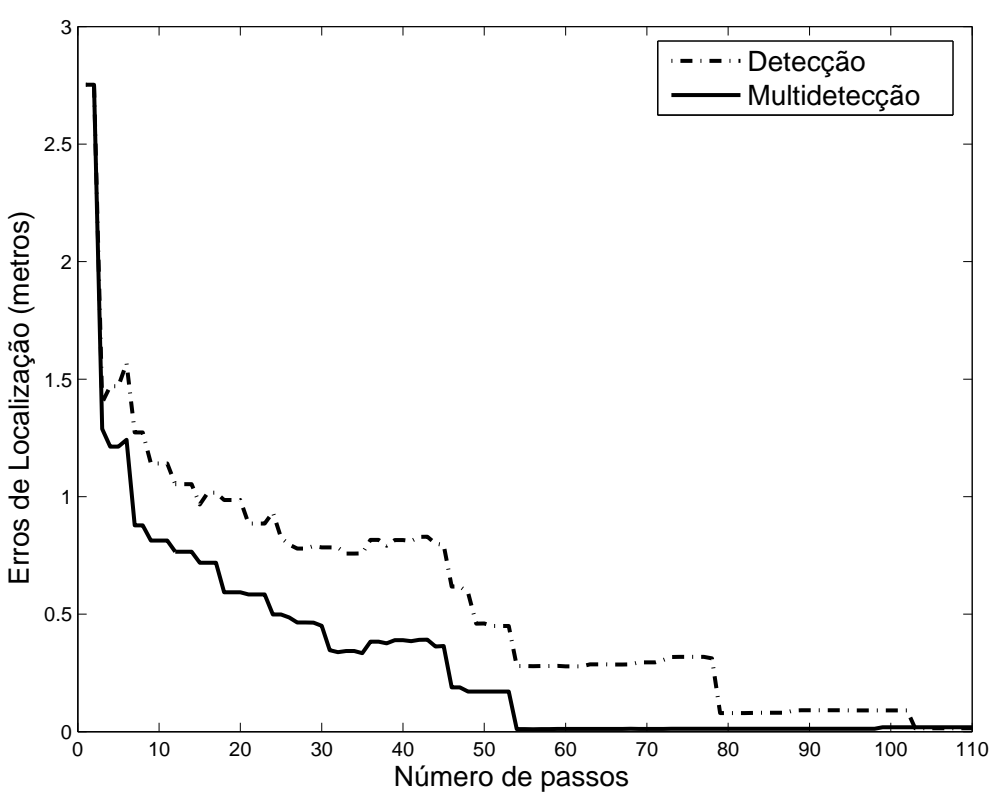

(a)

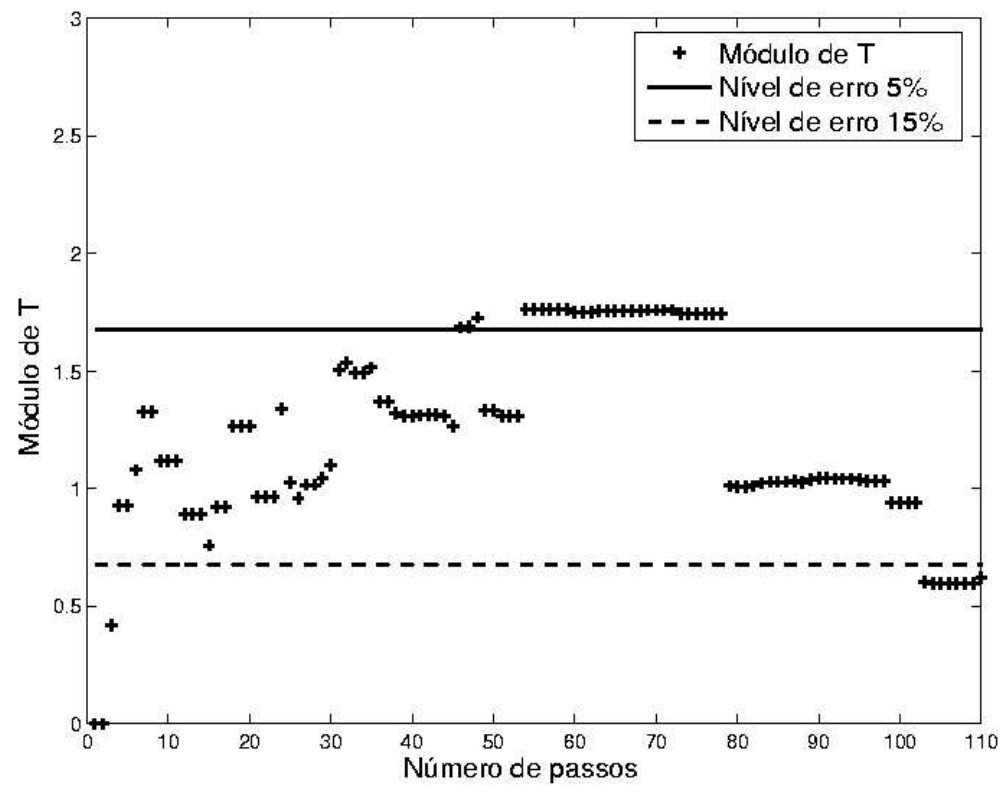

(b)

Figura 7.9: Comparação entre LMM e LMM acrescido do modelo de multidetecção com quatro robôs no ambiente aberto da Figura 7.1(b).(a) Erros de localização. (b) Resultado do teste $t$ de Student. 


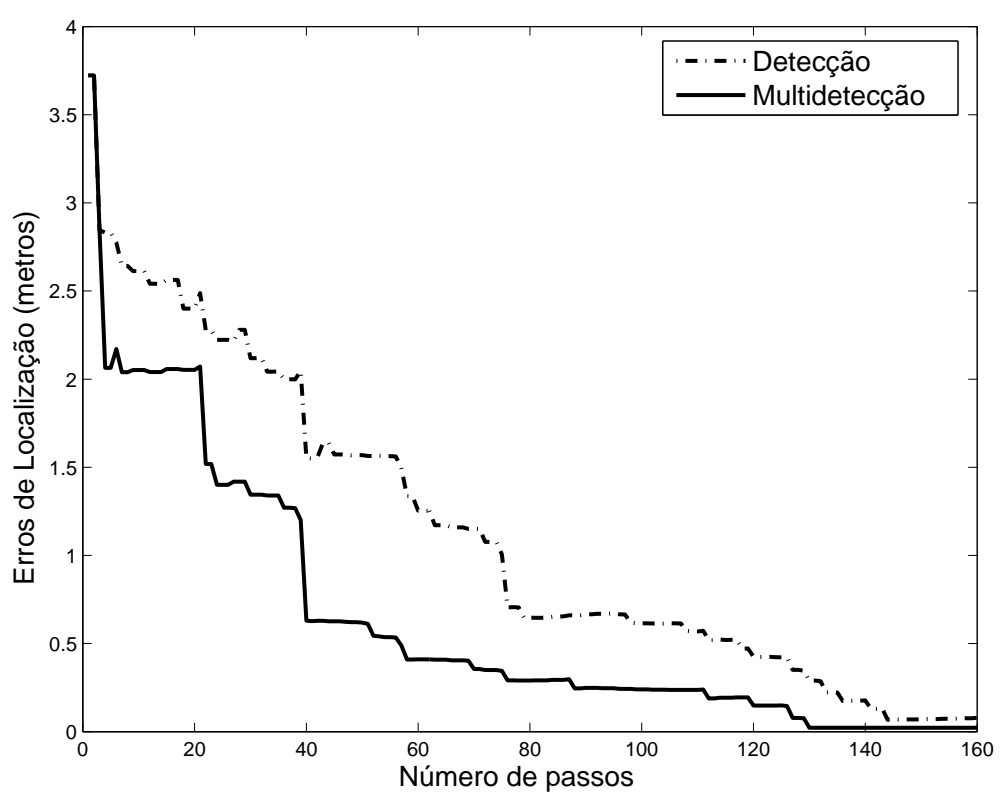

(a)

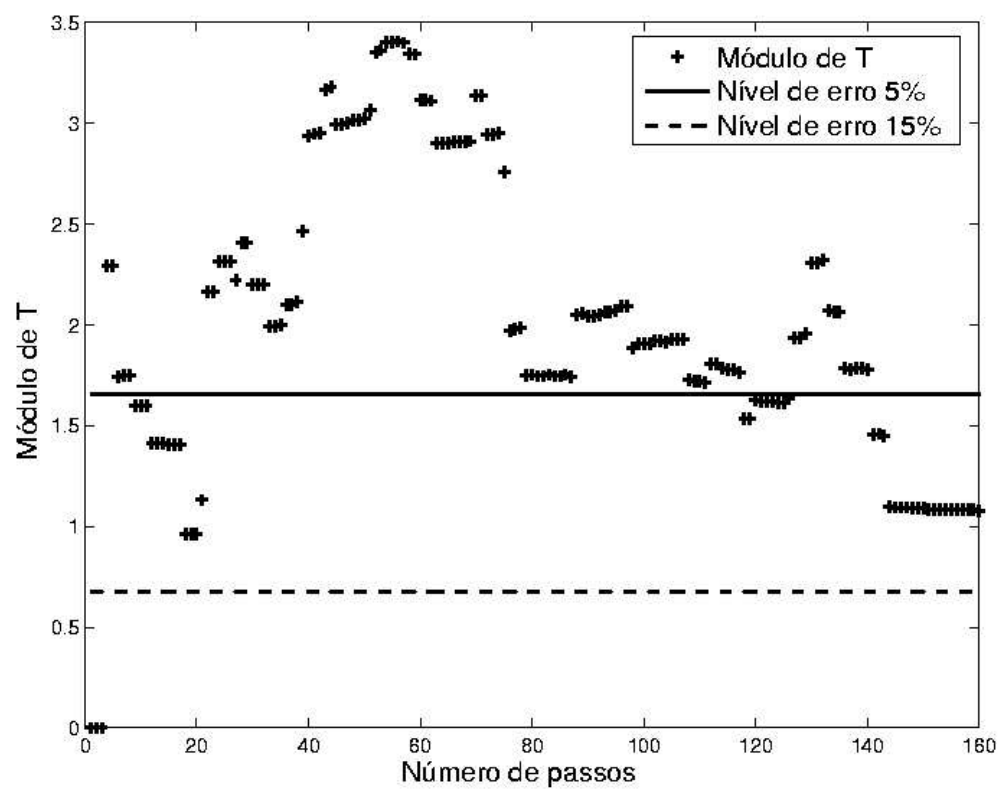

(b)

Figura 7.10: Comparação entre LMM e LMM acrescido do modelo de multidetecção com 8 robôs no ambiente de corredores da Figura 7.1(c). (a) Erros de localização. (b) Resultado do teste $t$ de Student. 


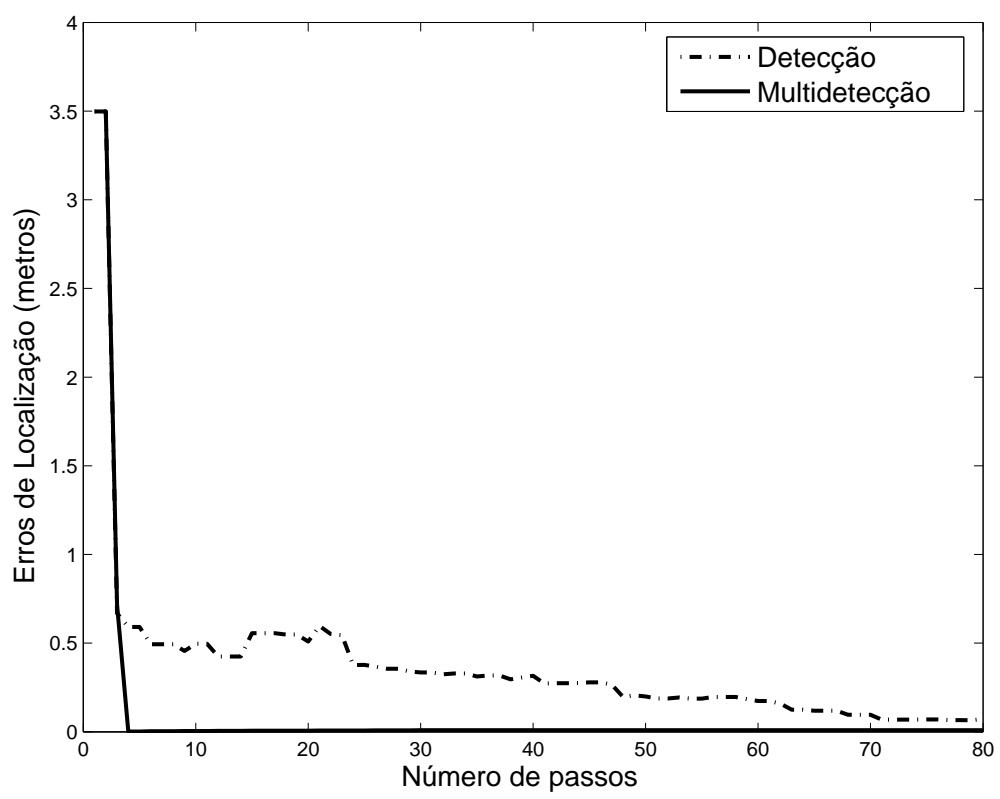

(a)

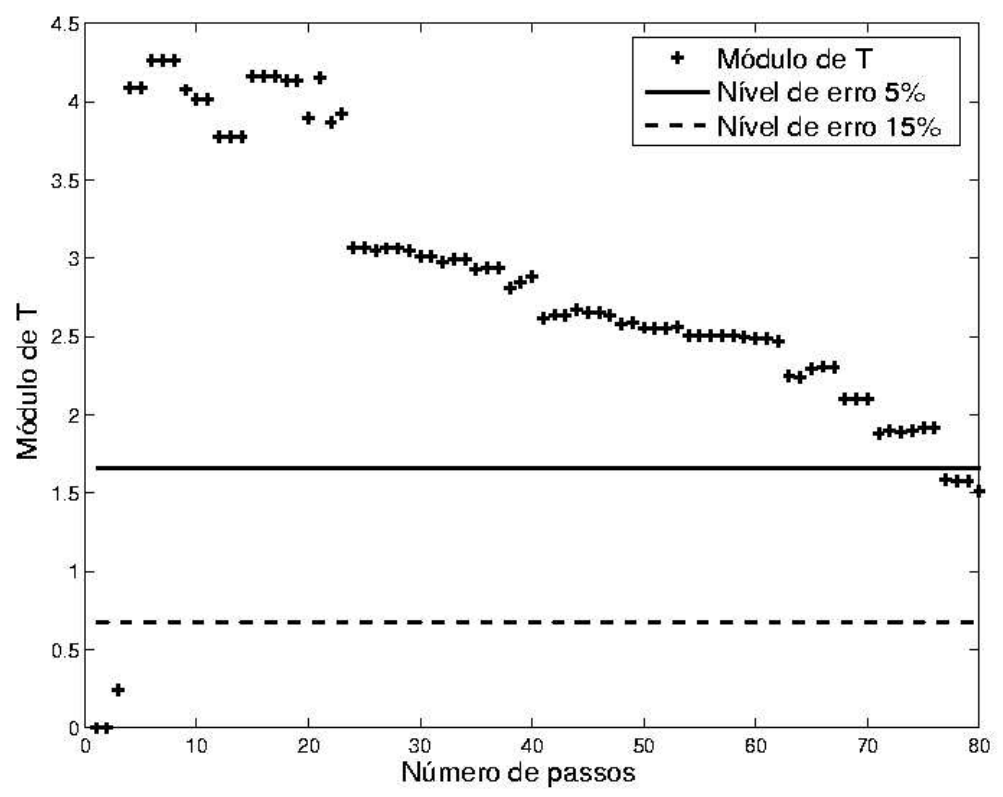

(b)

Figura 7.11: Comparação entre LMM e LMM acrescido do modelo de multidetecção com dez robôs no ambiente de salas da Figura 7.1(d). (a) Erros de localização. (b) Resultado do teste $t$ de Student. 


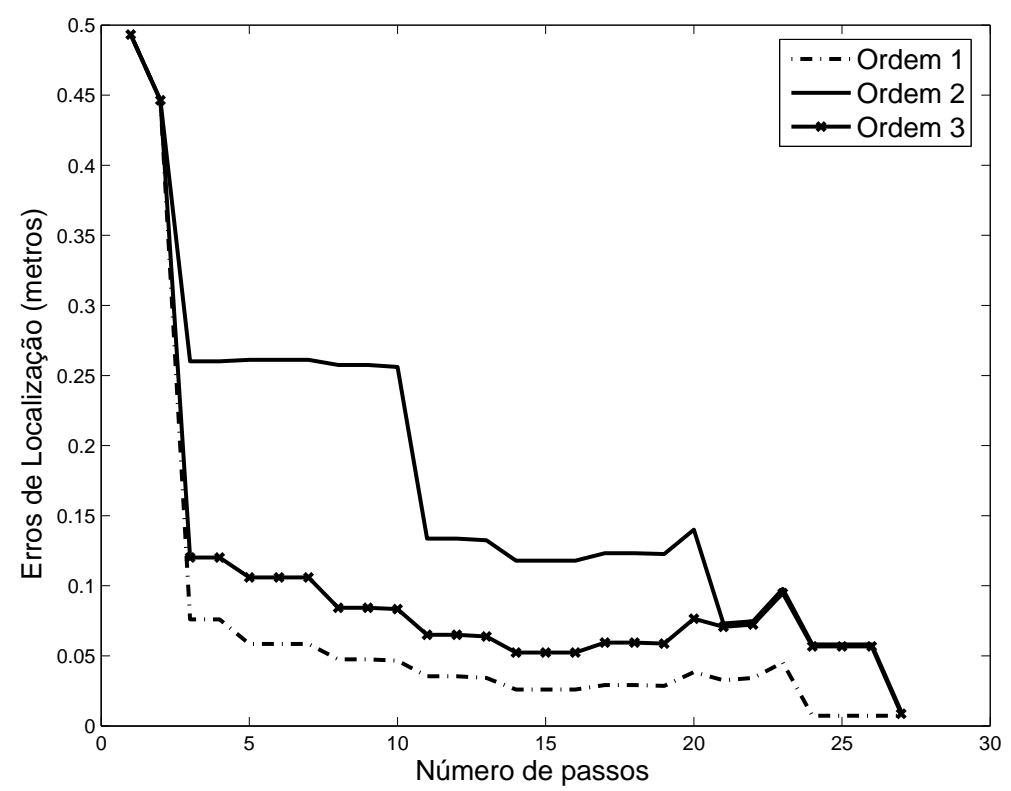

Figura 7.12: Comparação entre três ordens de atualização das crenças de posturas no ambiente simétrico da Figura 7.1(a) com 3 robôs. Ordem 1 - menor entropia (proposta), Ordem 2 - maior entropia, Ordem 3 - numérica.

atualização proposta, a ordem 1, apresentou os menores erros de localização.

\subsection{Integração dos Modelos}

Nesta seção são investigados os casos em que o robô utiliza a detecção negativa juntamente com a propagação de detecção positiva para estimar as posturas dos robôs e os casos em que os robôs atualizam suas crenças de postura utilizando a multidetecção combinada com a detecção negativa. Ambos os casos são comparados com a LMM.

Quatro experimentos foram executados e seus resultados são apresentados em gráficos que mostram o erro de localização pelo número de passos. O teste $t$ de Student foi realizado para os quatro experimentos. Foi calculado o valor do módulo de $T$ para cada passo. A Figura 7.16(a) mostra os resultados do primeiro experimento. Os valores de erro de localização são valores médios para três robôs em cinco execuções no ambiente da Figura 7.1(a). O resultado do teste $t$ de Student para este experimento é apresentado na Figura 7.16(b).

A Figura 7.17(a) mostra os resultados do segundo experimento. Os valores de erro de localização são valores médios para quatro robôs em seis execuções no ambiente da Figura 7.1(b). O resultado do teste $t$ de Student para este experimento é apresentado na Figura 7.17(b).

A Figura 7.18(a) mostra os resultados do terceiro experimento. Os valores de 


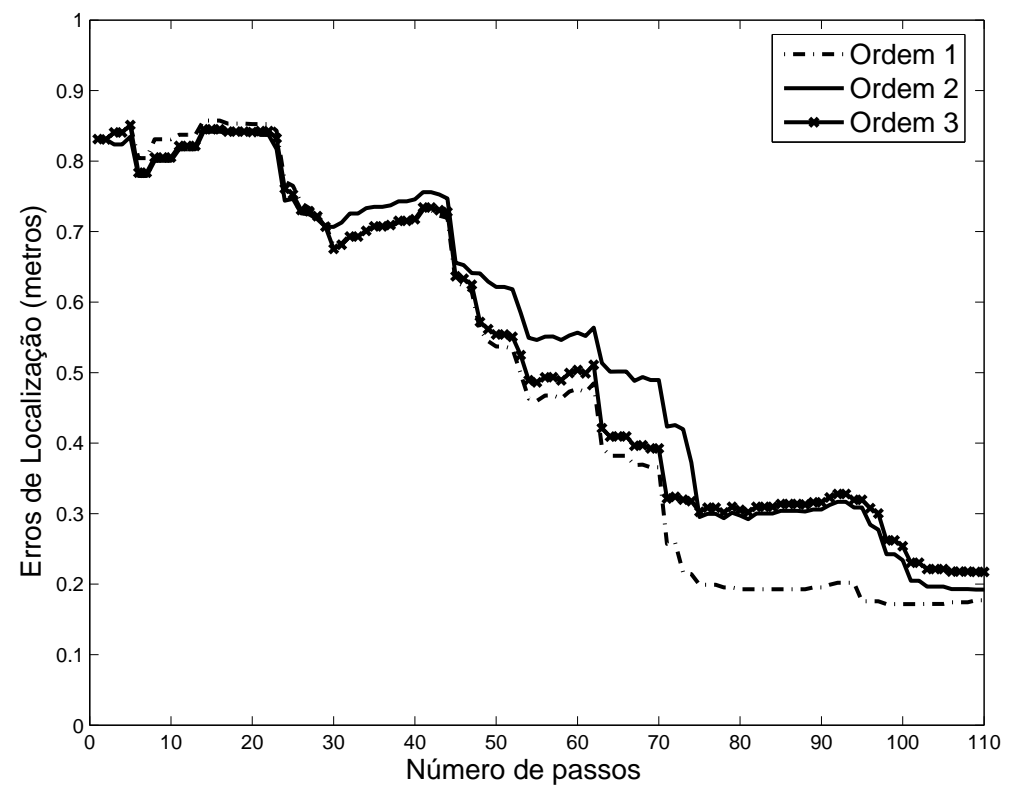

Figura 7.13: Comparação entre três ordens de atualização das crenças de posturas no ambiente aberto da Figura 7.1(b) com 4 robôs. Ordem 1 - menor entropia (proposta), Ordem 2 - maior entropia, Ordem 3 - numérica.

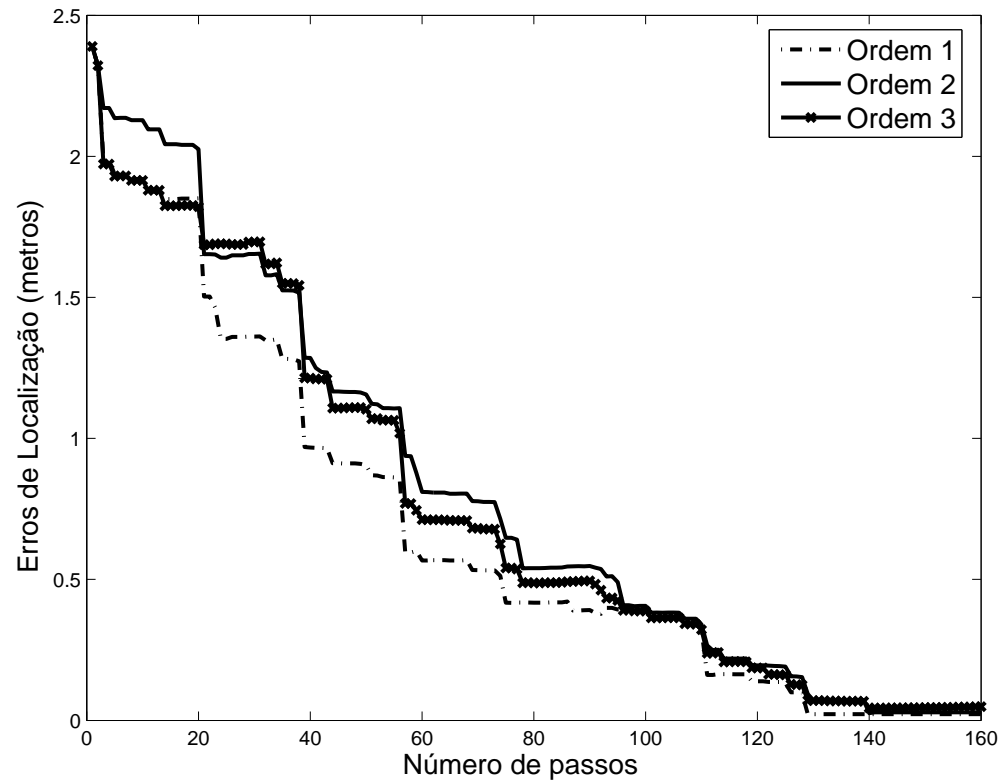

Figura 7.14: Comparação entre três ordens de atualização das crenças de posturas no ambiente de corredores da Figura 7.1(c) com 8 robôs. Ordem 1 menor entropia (proposta), Ordem 2 - maior entropia, Ordem 3 - numérica. 


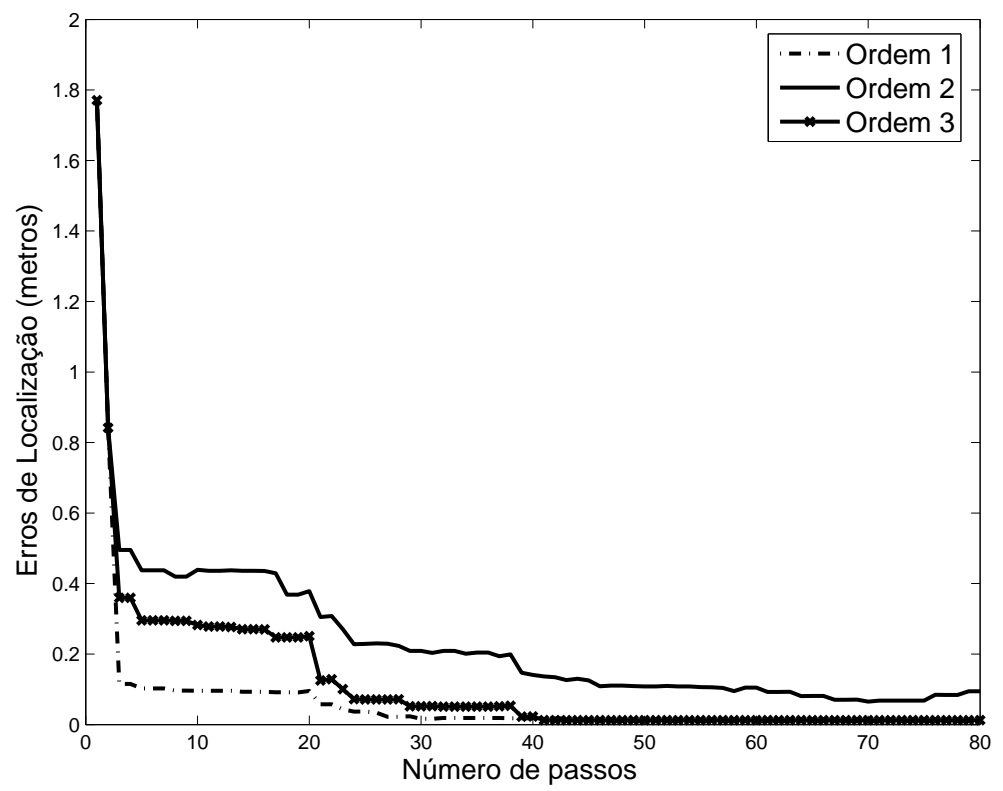

Figura 7.15: Comparação entre três ordens de atualização das crenças de posturas no ambiente de salas da Figura 7.1(d) com 10 robôs. Ordem 1 - menor entropia (proposta), Ordem 2 - maior entropia, Ordem 3 - numérica.

erro de localização são valores médios para oito robôs em oito execuções no ambiente da Figura 7.1(c). O resultado do teste $t$ de Student para este experimento é apresentado na Figura 7.18(b).

A Figura 7.19(a) mostra os resultados do quarto experimento. Os valores de erro de localização são valores médios para dez robôs em quatro execuções no ambiente da Figura 7.1(d). O resultado do teste $t$ de Student para este experimento é apresentado na Figura 7.19(b).

Em todos os experimentos apresentados a integração dos modelos de detecção negativa juntamente com a propagação da detecção positiva na LMM apresentou redução nos erros de localização. A redução nos erros de localização mostrou-se significante, com nível de erro de 15\%, em três dos experimentos, como pode ser verificado com a aplicação do teste $t$ de Student nas Figuras 7.16(b), 7.18(b) e 7.19(b). No entanto, na Figura 7.17(b), não foi verificada uma melhora significativa com a integração dos modelos de detecção negativa e de propagação da detecção positiva, como já esperado, uma vez que cada uma dessas técnicas sozinhas não havia melhorado as estimativas de posturas.

Os casos em que os robôs atualizam suas crenças de postura utilizando a multidetecção combinada com a deteç̧ão negativa são mostrados nas Figuras 7.20(a), 7.21(a), 7.22(a) e 7.23(a). Em todos os gráficos os erros de localização diminuem se comparados com a localização com detecção positiva.

A diminuição nos erros de localização mostrou-se significante em todos os 


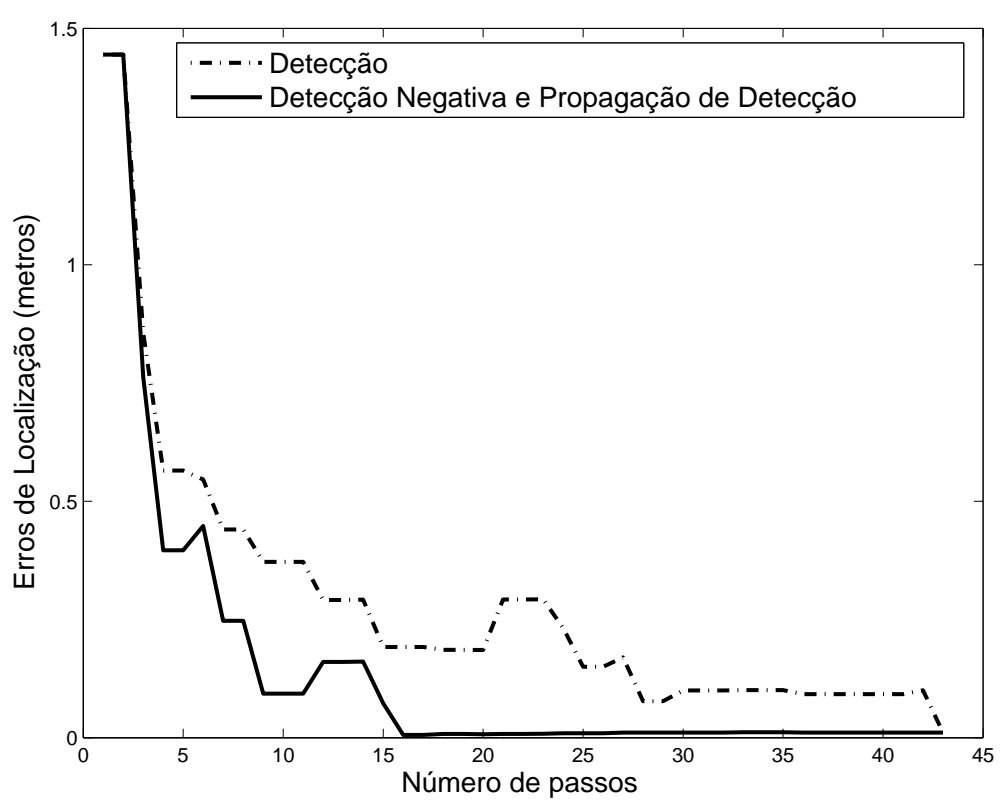

(a)

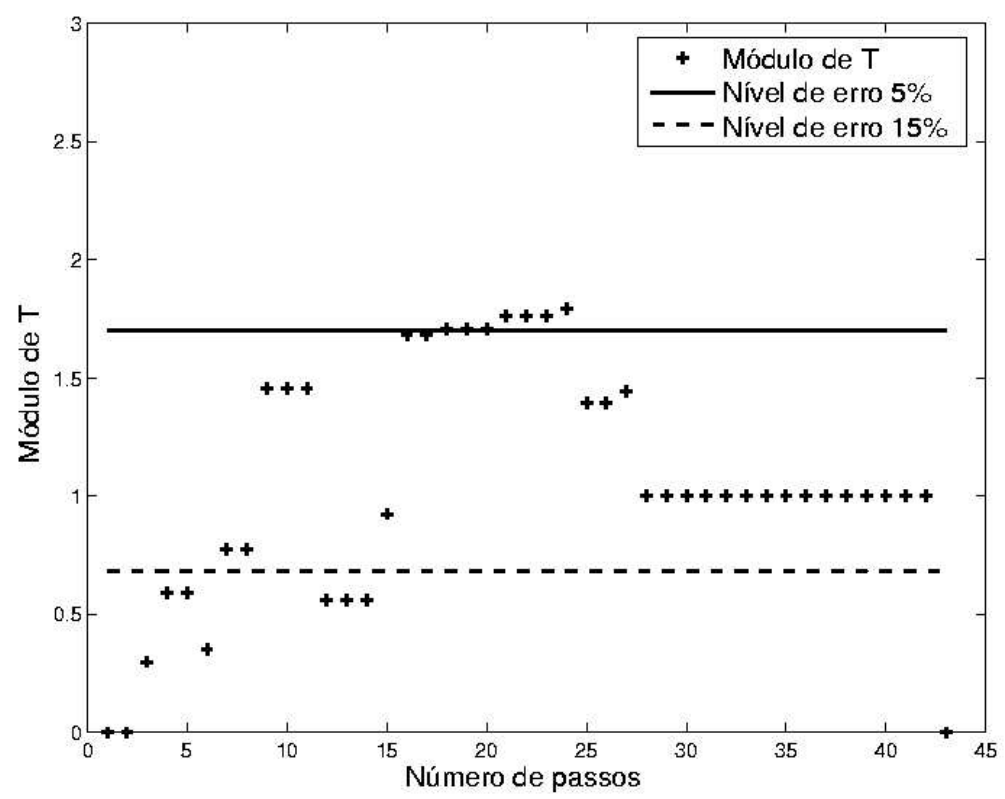

(b)

Figura 7.16: Comparação entre LMM e LMM acrescido dos modelos de detecção negativa e propagação da detecção positiva com três robôs no ambiente simétrico da Figura 7.1(a). (a) Erros de localização. (b) Resultado do teste $t$ de Student. 


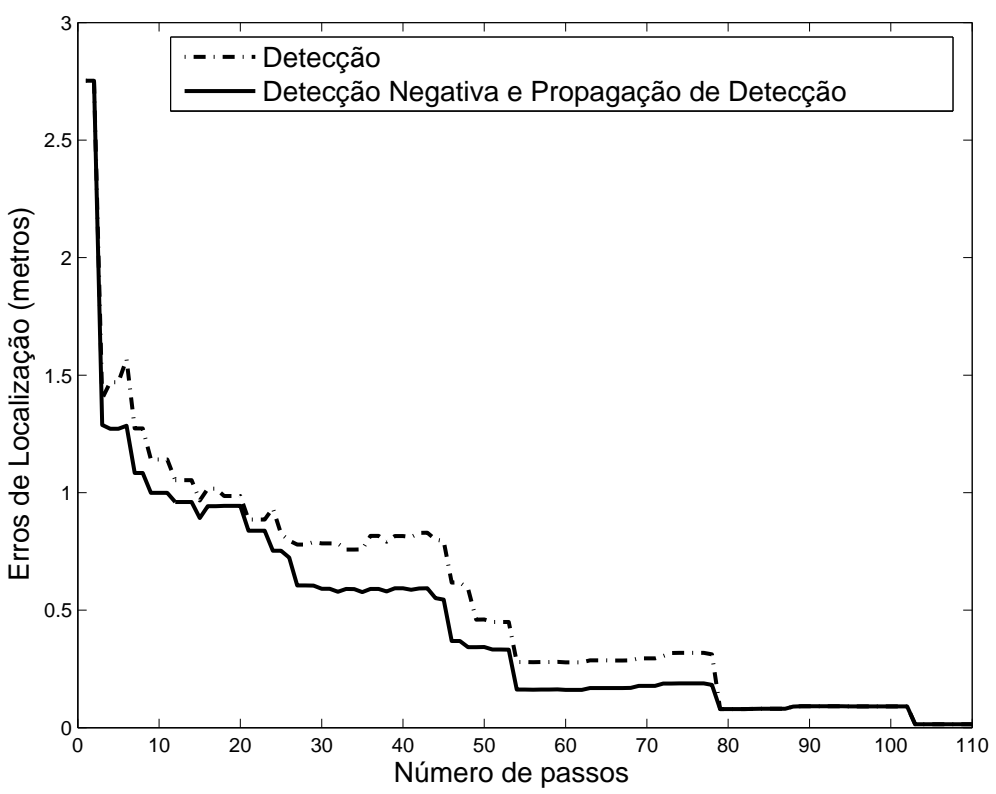

(a)

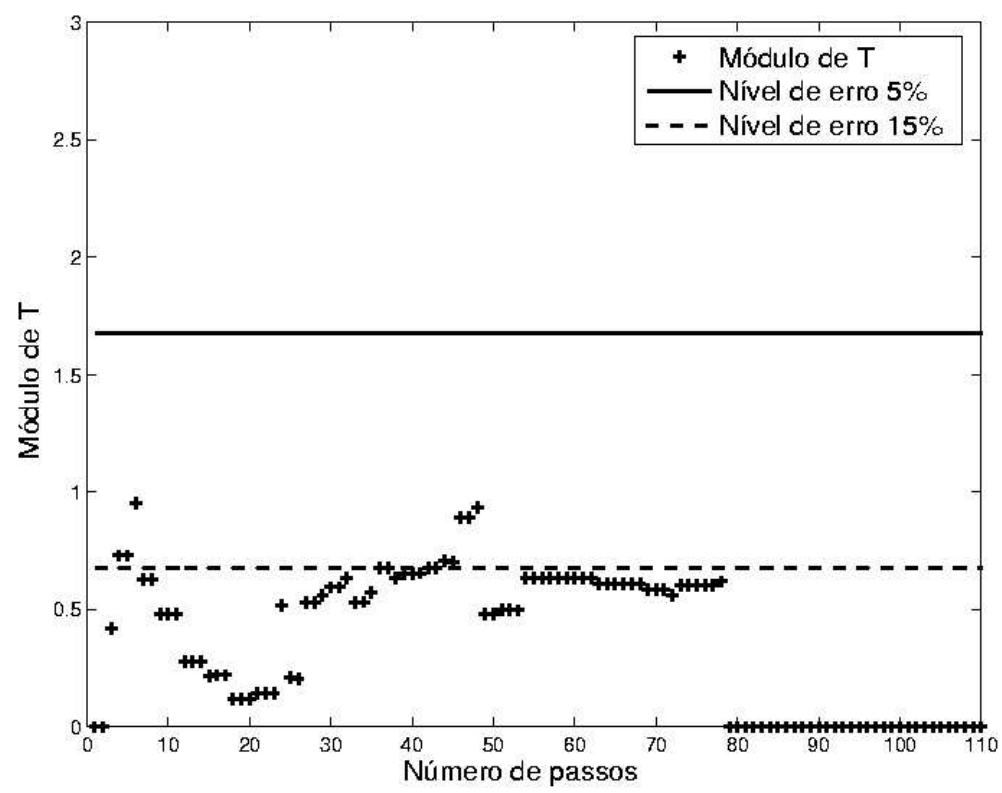

(b)

Figura 7.17: Comparação entre LMM e LMM acrescido dos modelos de detecção negativa e propagação da detecção positiva com quatro robôs no ambiente aberto da Figura 7.1(b). (a) Erros de localização. (b) Resultado do teste $t$ de Student. 


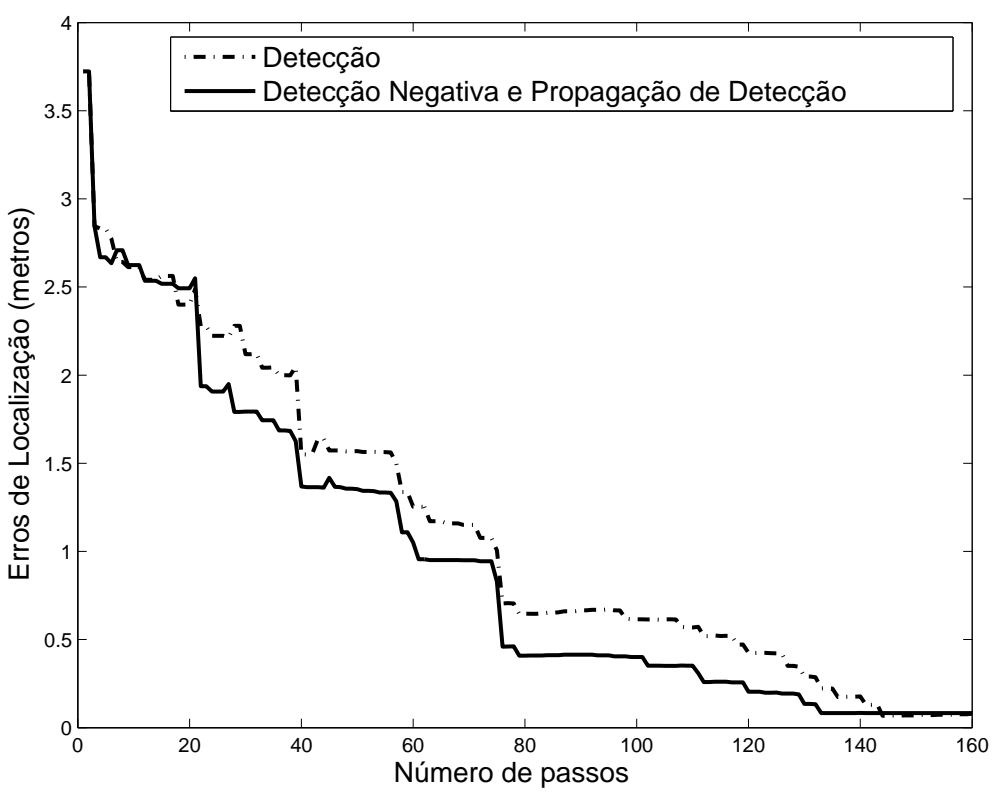

(a)

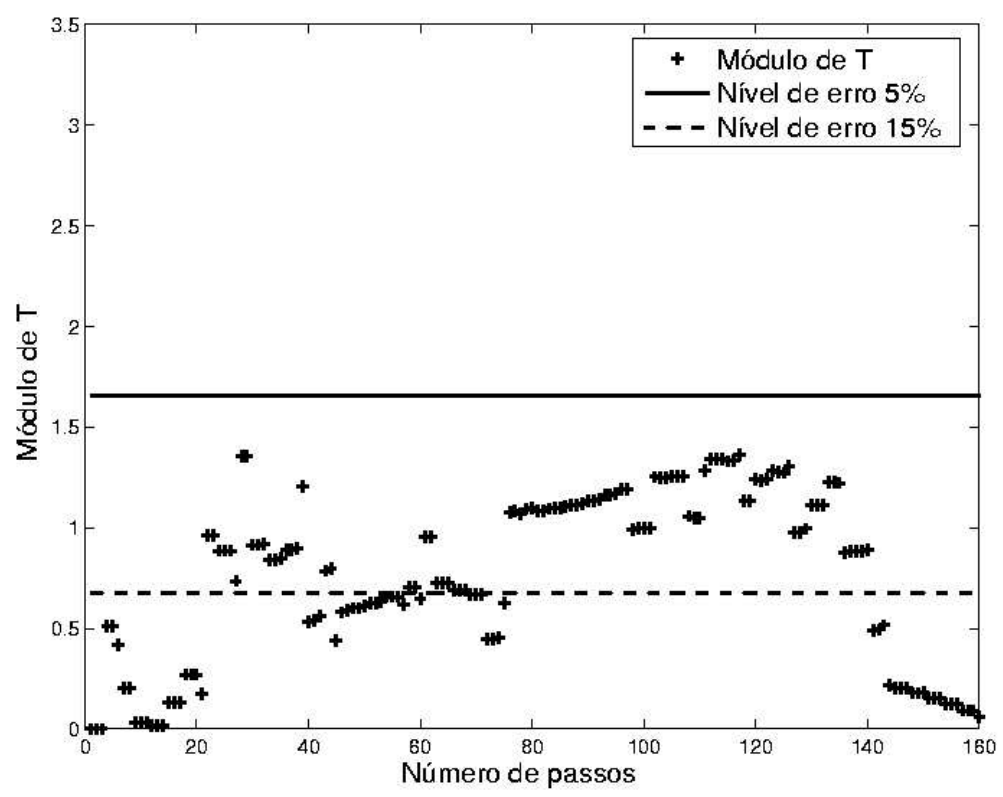

(b)

Figura 7.18: Comparação entre LMM e LMM acrescido dos modelos de detecção negativa e propagação da detecção positiva com oito robôs no ambiente de corredores da Figura 7.1(c). (a) Erros de localização. (b) Resultado do teste $t$ de Student. 


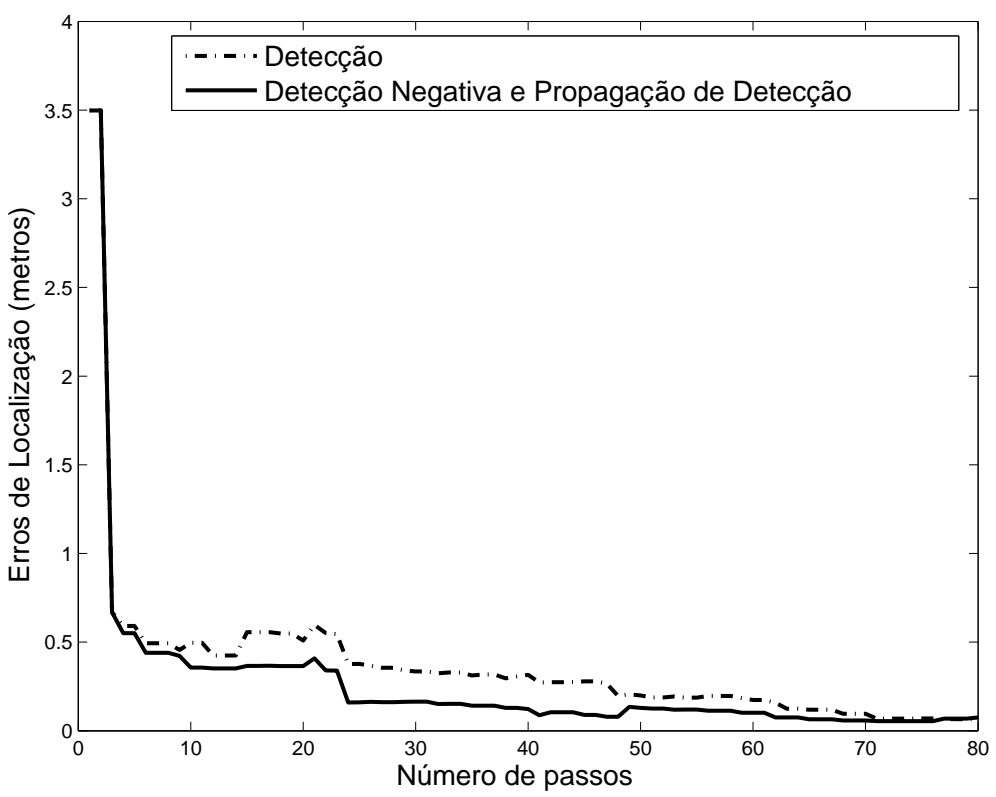

(a)

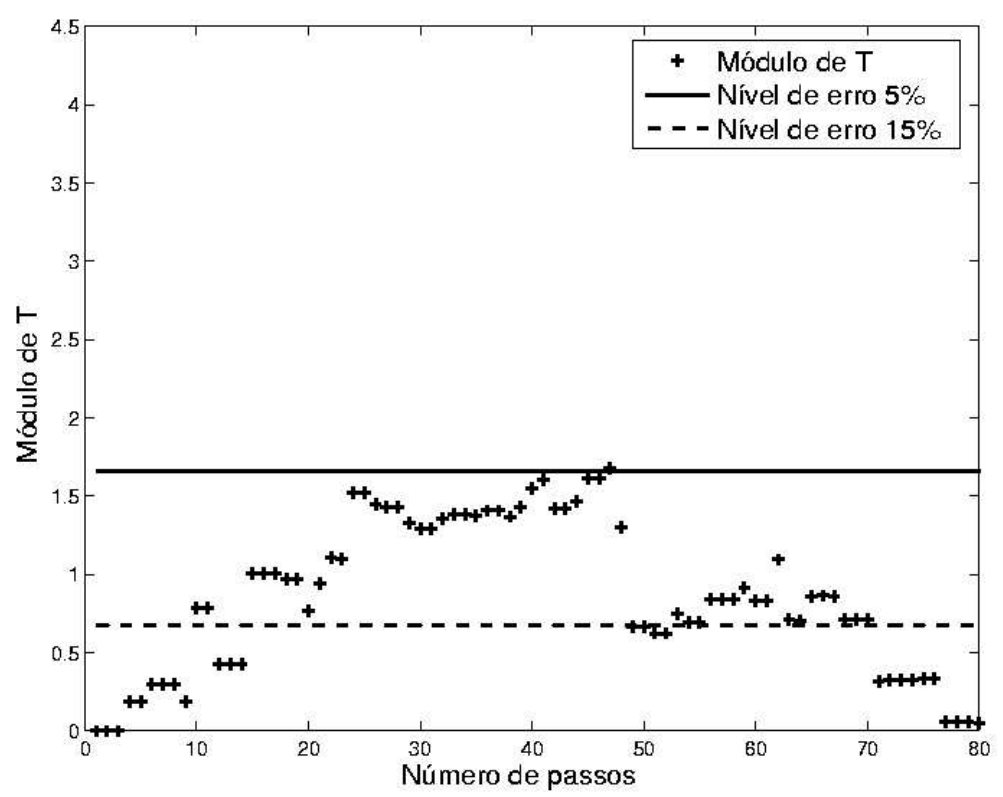

(b)

Figura 7.19: Comparação entre LMM e LMM acrescido dos modelos de detecção negativa e propagação da detecção positiva com dez robôs no ambiente de salas da Figura 7.1(d). (a) Erros de localização. (b) Resultado do teste $t$ de Student. 


\begin{tabular}{|c|c|c|c|c|}
\hline $\begin{array}{l}\text { Detecção } \\
\text { Negativa }\end{array}$ & $\begin{array}{l}\text { Propagação } \\
\text { Positiva }\end{array}$ & $\begin{array}{c}\text { Detecção } \\
\text { Negativa e } \\
\text { Propagação } \\
\text { Positiva }\end{array}$ & Multidetecção & $\begin{array}{c}\text { Multidetecção e } \\
\text { Detecção } \\
\text { Negativa }\end{array}$ \\
\hline $7.3(\mathrm{a})$ & $\begin{array}{c}7.4(\mathrm{a}), 7.5(\mathrm{a}), \\
\mathbf{7 . 6 ( a )} \text { e } \mathbf{7 . 7 ( a )}\end{array}$ & $\begin{array}{c}7.16(\mathrm{a}), 7.17(\mathrm{a}) \\
7.18(\mathrm{a}) \text { e } 7.19(\mathrm{a})\end{array}$ & $\begin{array}{c}7.8(\mathrm{a}), 7.9(\mathrm{a}), \\
\mathbf{7 . 1 0}(\mathrm{a}) \text { e } \mathbf{7 . 1 1}(\mathrm{a})\end{array}$ & $\begin{array}{c}7.20(\mathrm{a}), 7.21(\mathrm{a}), \\
\mathbf{7 . 2 2}(\mathrm{a}) \text { e } \mathbf{7 . 2 3 ( a )}\end{array}$ \\
\hline
\end{tabular}

Tabela 7.1: Resumo dos experimentos de comparação entre LMM e modelos propostos na tese, referência as figuras dos experimentos correspondentes.

experimentos, como pode ser verificado com a aplicação do teste $t$ de Student nas Figuras 7.20(b), 7.21(b), 7.22(b) e 7.23(b). Nos dois primeiros experimentos o nível de erro é de $15 \%$ e nos dois últimos de 5\%. Estes resultados comprovam mais uma vez que para os ambientes das Figura 7.1(c) e 7.1(d), com mais robôs, obtiveram os melhores resultados, pois se beneficiam da multidetecção.

Na Tabela 7.1 pode ser visto o resumo dos experimentos realizados. Os experimentos comparam a LMM com a LMM acrescida dos modelos propostos na tese. Cada valor da segunda linha representa o índice da figura na qual o experimento é ilustrado. Os valores em negrito representam os casos em que houve uma melhora significativa nos resultados ao incorporar os novos modelos, ou seja, com nível de erro menor que $15 \%$ quando aplicado o teste $t$ de Student.

\subsection{Reduzindo Comunicação}

Nesta seção são apresentados experimentos que comprovam a redução do número de mensagens trocadas entre os robôs quando se utiliza o valor de entropia para restringir a comunicação nos casos em que esta não é considerada útil.

Os gráficos desta seção mostram o valor médio de entropia da crença de postura dos robôs pelo número de passos, com a média calculada em função tanto do número de robôs quanto do número de repetições do experimento. O valor de entropia $H$ é normalizado, com valor 1 quando a crença da postura do robô é totalmente incerta e com valor 0 quando a crença na postura do robô está centrada em uma única posição do ambiente, ou seja, o robô está certo sobre sua postura. São testados dois valores de limiar entropia, $H=1$ representando a comunicação a todo o momento que uma nova evidência é obtida, independente de quão certo cada robô esteja sobre sua postura, e limiar $H=0.03$ representando a comunicação apenas quando os robôs que transmitem mensagens estão certos sobre suas posturas.

O número de mensagens comunicadas $N C$ reduz significativamente se a co- 


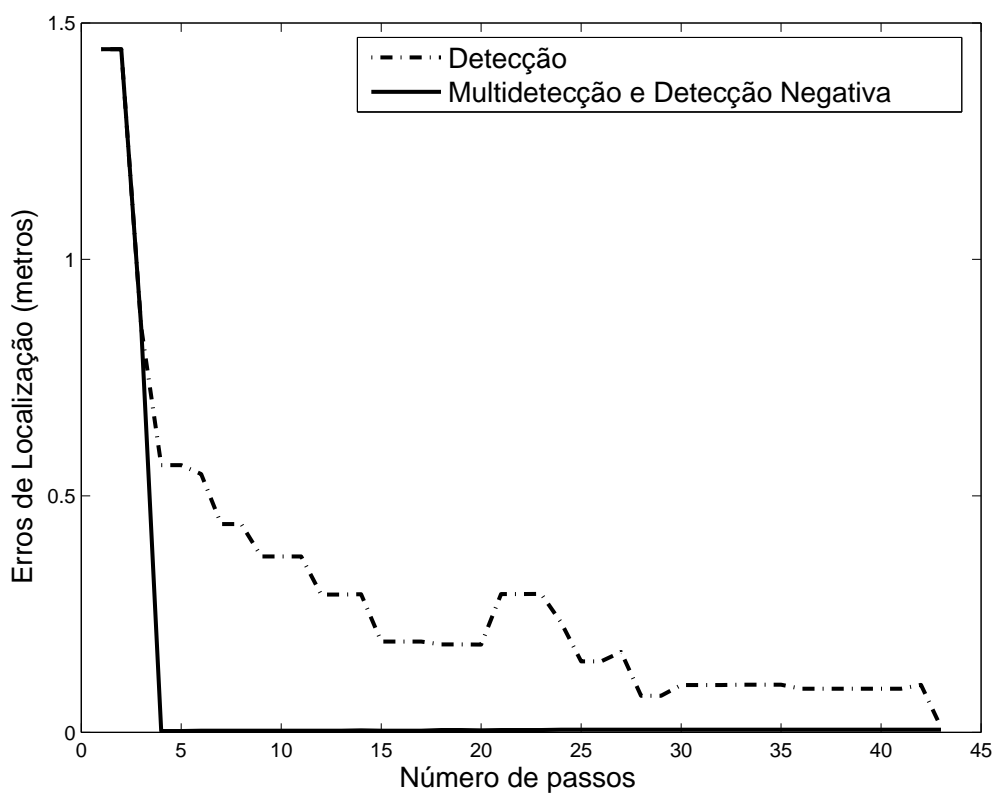

(a)

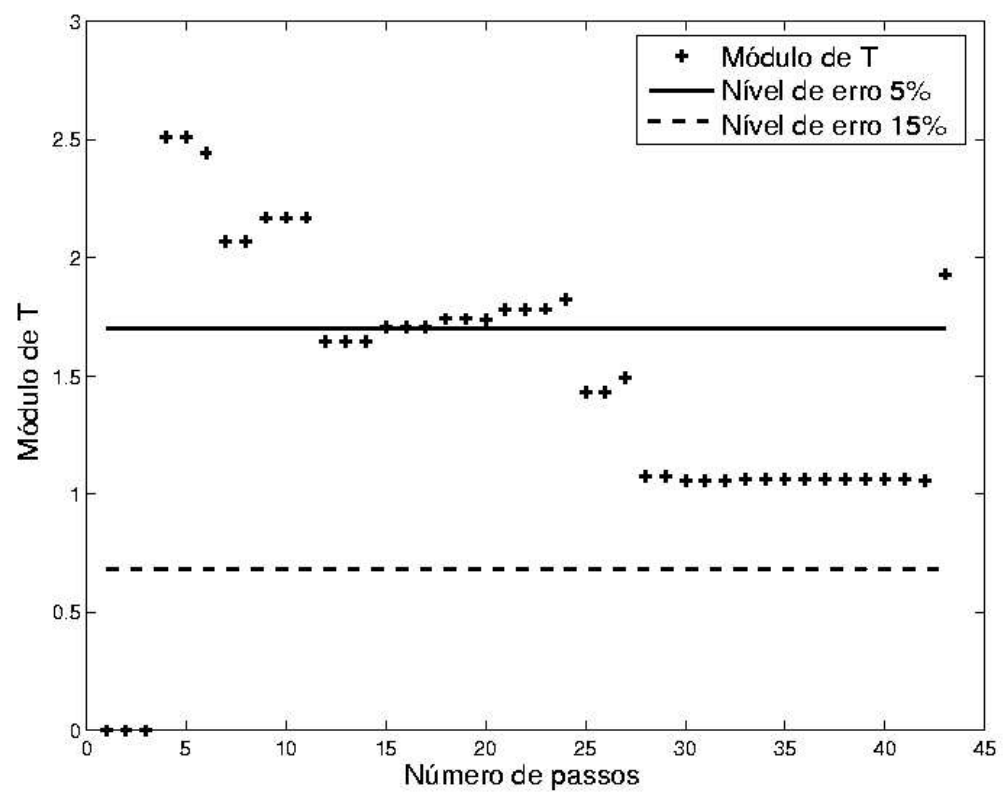

(b)

Figura 7.20: Comparação entre LMM e LMM acrescido dos modelos de multidetecção e detecção negativa com três robôs no ambiente simétrico da Figura 7.1(a). (a) Erros de localização. (b) Resultado do teste $t$ de Student. 


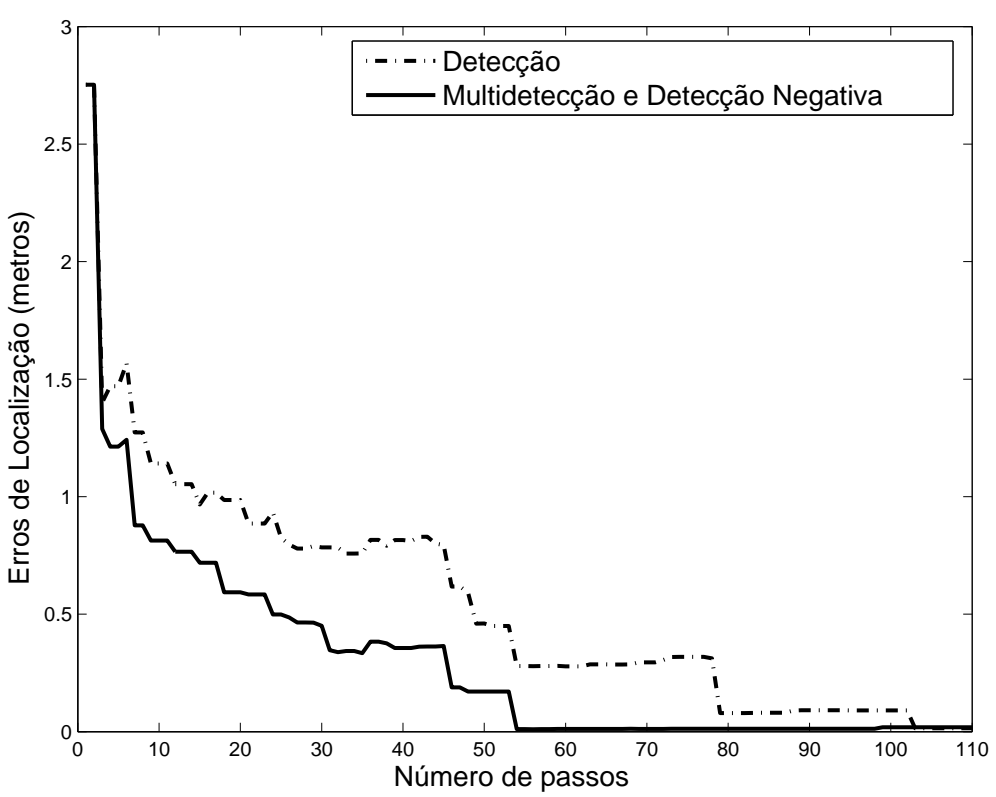

(a)

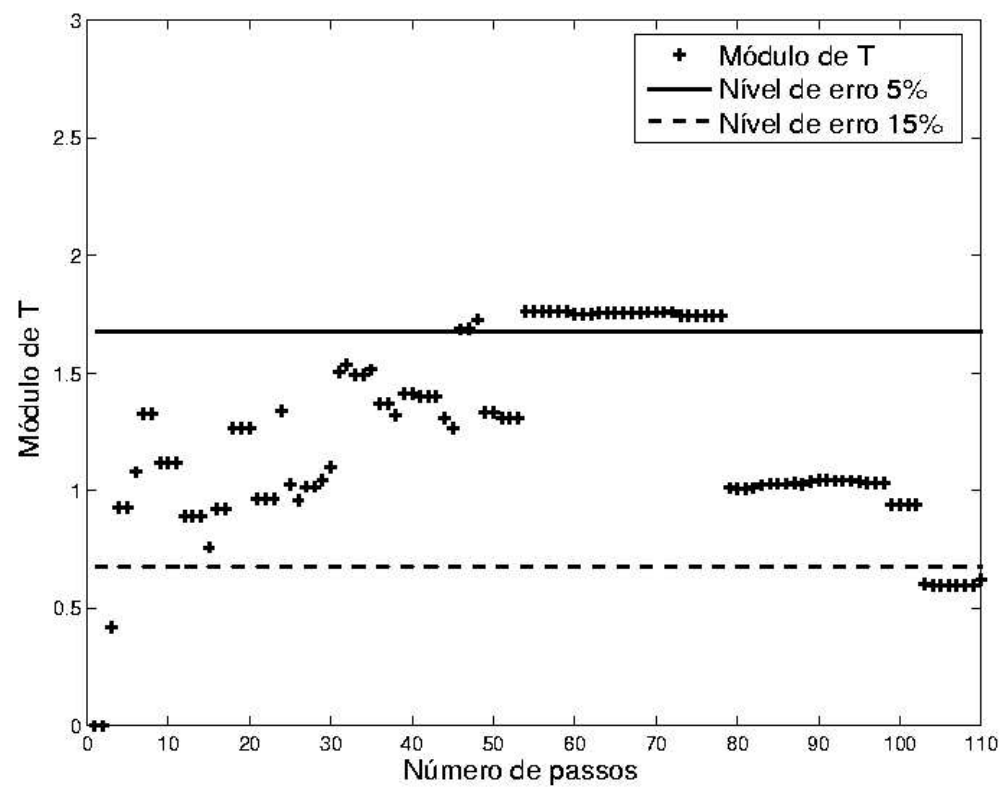

(b)

Figura 7.21: Comparação entre LMM e LMM acrescido dos modelos de multidetecção e detecção negativa com quatro robôs no ambiente aberto da Figura 7.1(b). (a) Erros de localização. (b) Resultado do teste $t$ de Student. 


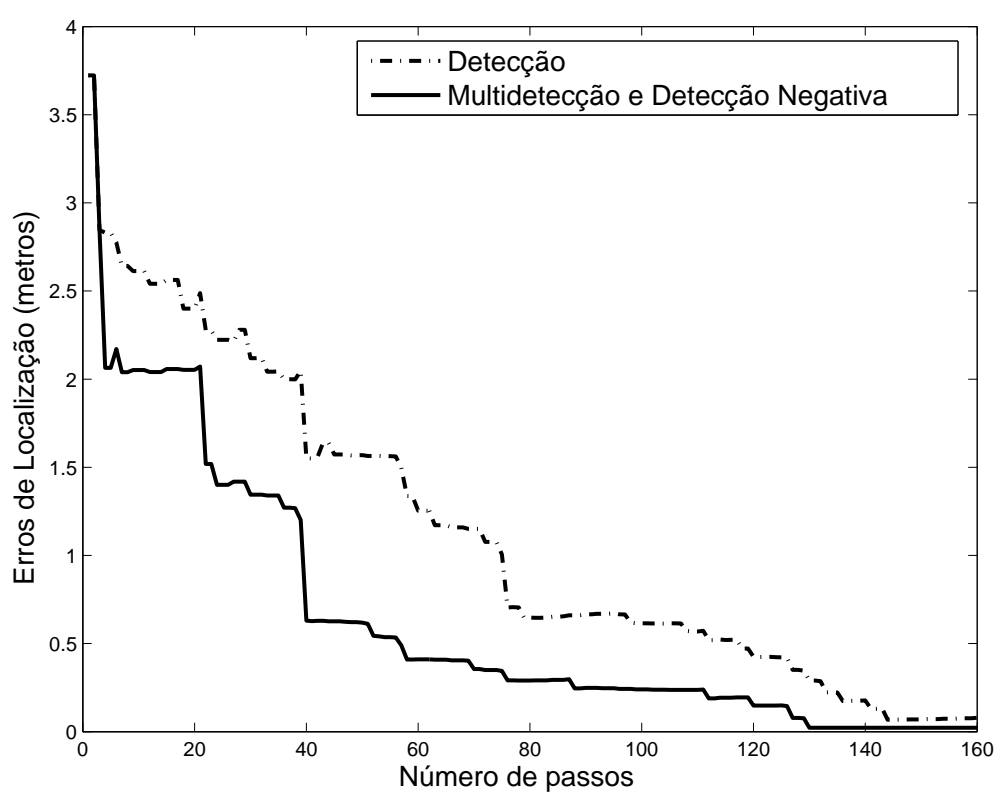

(a)

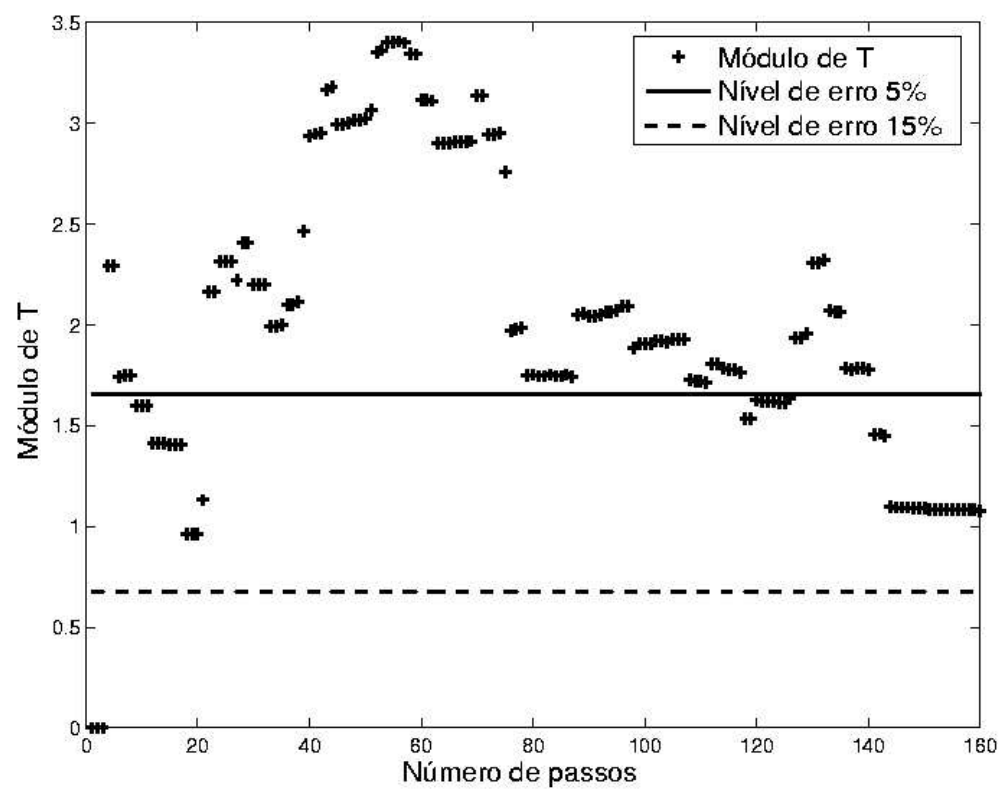

(b)

Figura 7.22: Comparação entre LMM e LMM acrescido dos modelos de multidetecção e detecção negativa com oito robôs no ambiente de corredores da Figura 7.1(c). (a) Erros de localização. (b) Resultado do teste $t$ de Student. 


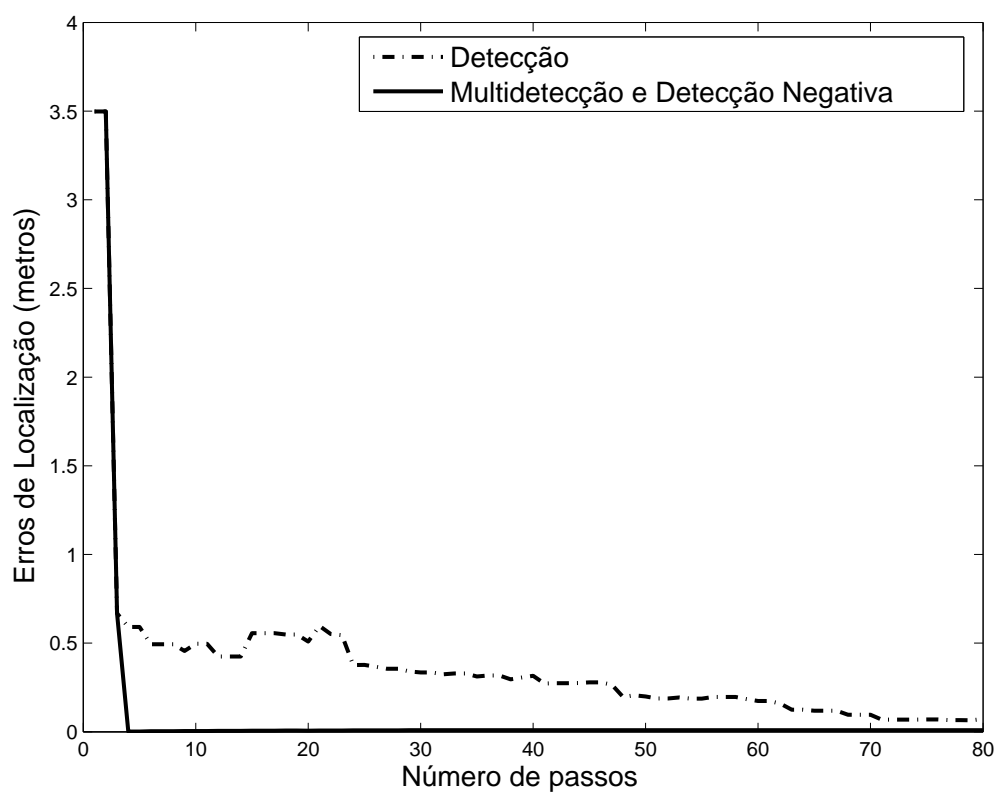

(a)

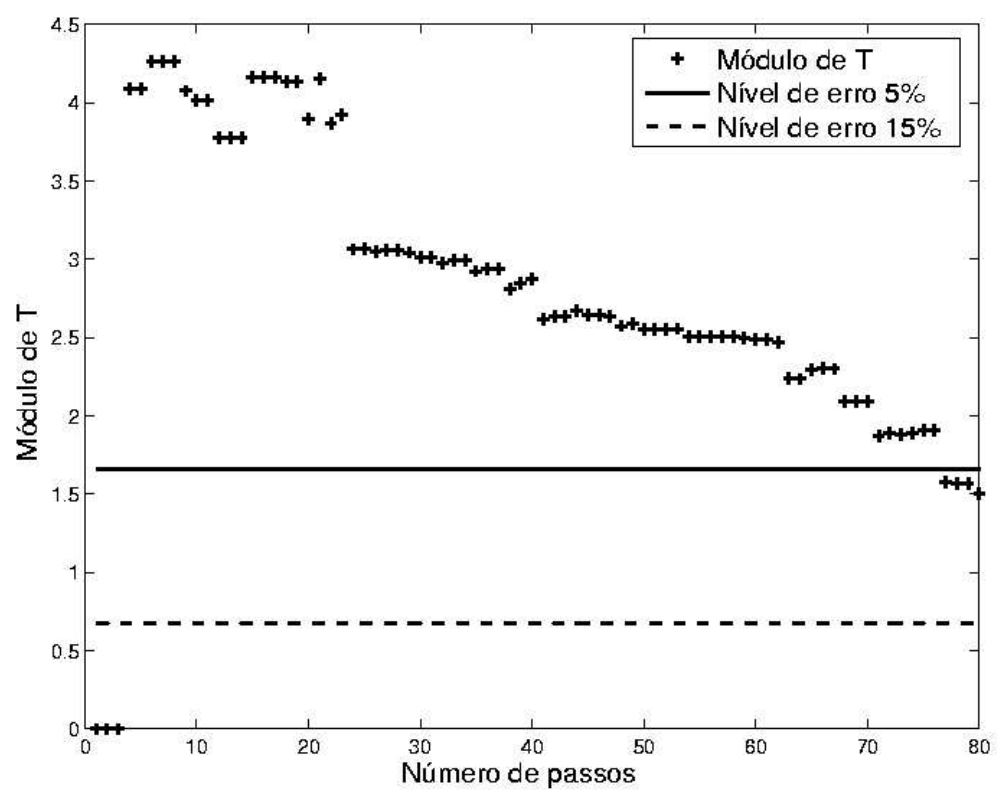

(b)

Figura 7.23: Comparação entre LMM e LMM acrescido dos modelos de multidetecção e detecção negativa com dez robôs no ambiente de salas da Figura 7.1(d). (a) Erros de localização. (b) Resultado do teste $t$ de Student. 


\begin{tabular}{|c||c|c|c|c|c|c|c|c|}
\hline \hline Ambientes & \multicolumn{2}{|c|}{ Simétrico } & \multicolumn{2}{|c|}{ Aberto } & \multicolumn{2}{c|}{ Corredores } & \multicolumn{2}{|c|}{ Salas } \\
\hline$L C$ & 0.03 & 1.0 & 0.03 & 1.0 & 0.03 & 1.0 & 0.03 & 1.0 \\
\hline \hline Deteç̧ão & 9 & 10 & 13 & 38 & 44 & 142 & 34 & 60 \\
\hline Multidetecção & 10 & 13 & 17 & 44 & 55 & 160 & 36 & 43 \\
\hline \hline
\end{tabular}

Tabela 7.2: Resumo dos experimentos de redução de comunicação para os casos de detecção e multidetecção.

municação é permitida apenas quando os robôs que transmitem informação estão certos sobre suas posturas, $H=0.03$. Isto pode ser percebido nas Figuras 7.24(a), 7.25(a), 7.26(a) e 7.27(a), para o caso de detecção única, e nas Figuras 7.24(b), 7.25(b), 7.26(b) e 7.27(b), para o caso de multidetecção. A Figura 7.24 reflete os resultados de três robôs em cinco experimentos, no ambiente da Figura 7.1(a). A Figura 7.25 reflete o resultado de seis experimentos com quatro robôs no ambiente da Figura 7.1(b). A Figura 7.26 reflete os resultados de oito experimentos com oito robôs no ambiente da Figura 7.1(c), e finalmente, a Figura 7.27 reflete os resultados de quatro experimentos para dez robôs na Figura 7.1(d).

Para os casos das Figuras 7.27(a) e 7.25(b), a redução na quantidade de mensagens trocadas foi de aproximadamente metade, enquanto que esse número chega a três vezes nos experimentos das Figuras 7.25(a), 7.26(a) e 7.27(b).

Esta redução na comunicação não afeta drasticamente a acurácia da informação de posturas dos robôs, não apresentando resultados significativamente diferentes com a aplicação do teste $t$ de Student.

Os resultados dos experimentos realizados empregando redução de comunicação são mostrados na Tabela 7.2. Os experimentos compararam método mais comunicativo $L C=1.0 \mathrm{com}$ menos comunicativo $L C=0.03$. Os valores mostrados na tabela são o número de mensagens trocadas para cada caso. O limiar $L C=0.03$ reduz a quantidade de mensagens trocadas para todos os casos.

\subsection{Discussão}

A atualização das crenças de posturas dos robôs utilizando toda informação disponível comprovadamente reduz os erros de localização, contribuindo para que o grupo de robôs encontre suas posturas em relação ao ambiente de forma mais rápida.

No entanto, a utilização de uma quantidade grande de informações para atualização das posturas implica em um maior tempo de processamento para calcular 


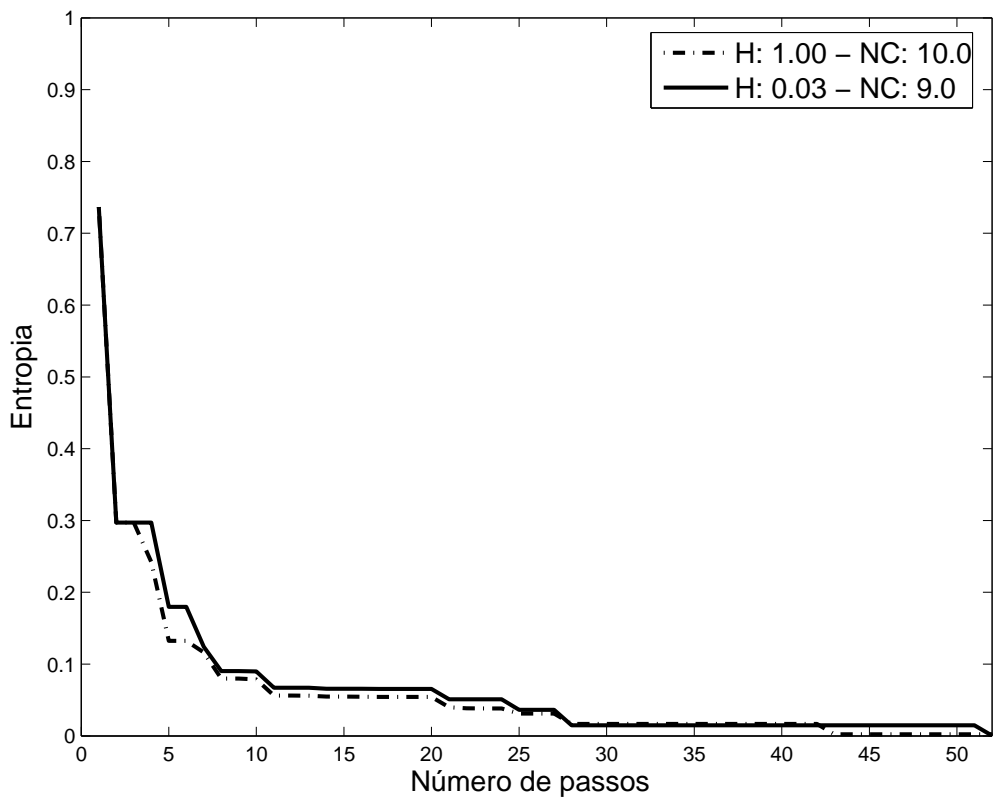

(a)

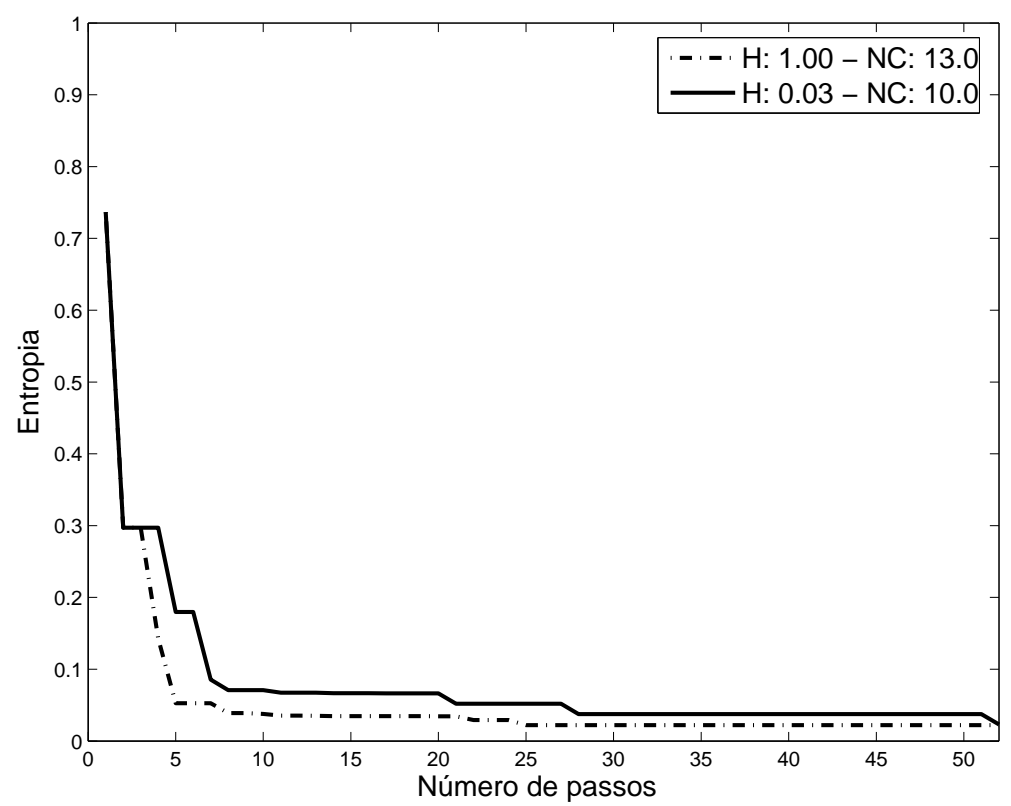

(b)

Figura 7.24: Comparação entre técnicas mais e menos comunicativas com três robôs no ambiente simétrico da Figura 7.1(a). (a) Detecção. (b) Multidetecção. 


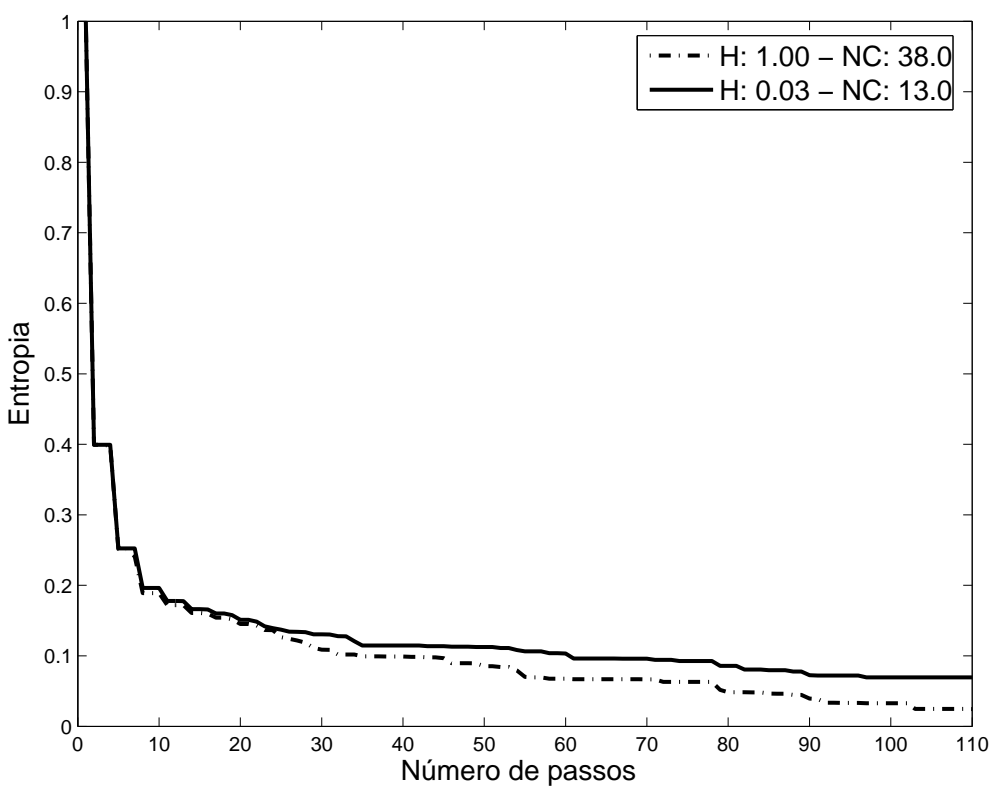

(a)

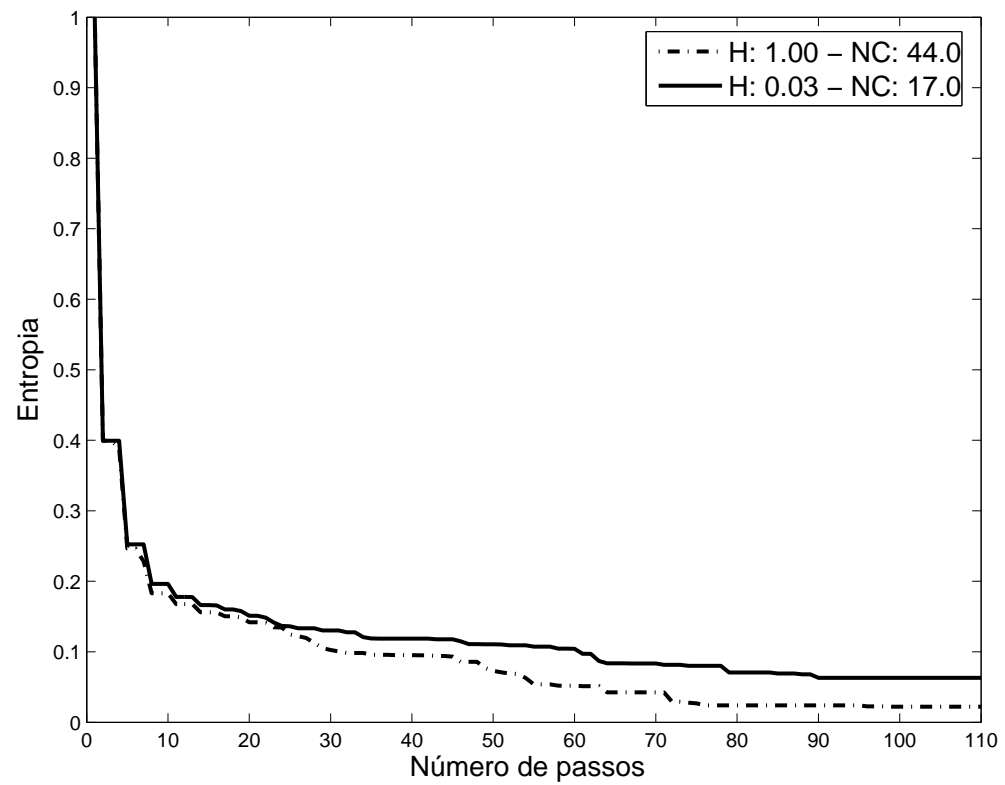

(b)

Figura 7.25: Comparação entre técnicas mais e menos comunicativas com quatro robôs no ambiente aberto da Figura 7.1(b). (a) Detecção. (b) Multidetecção. 


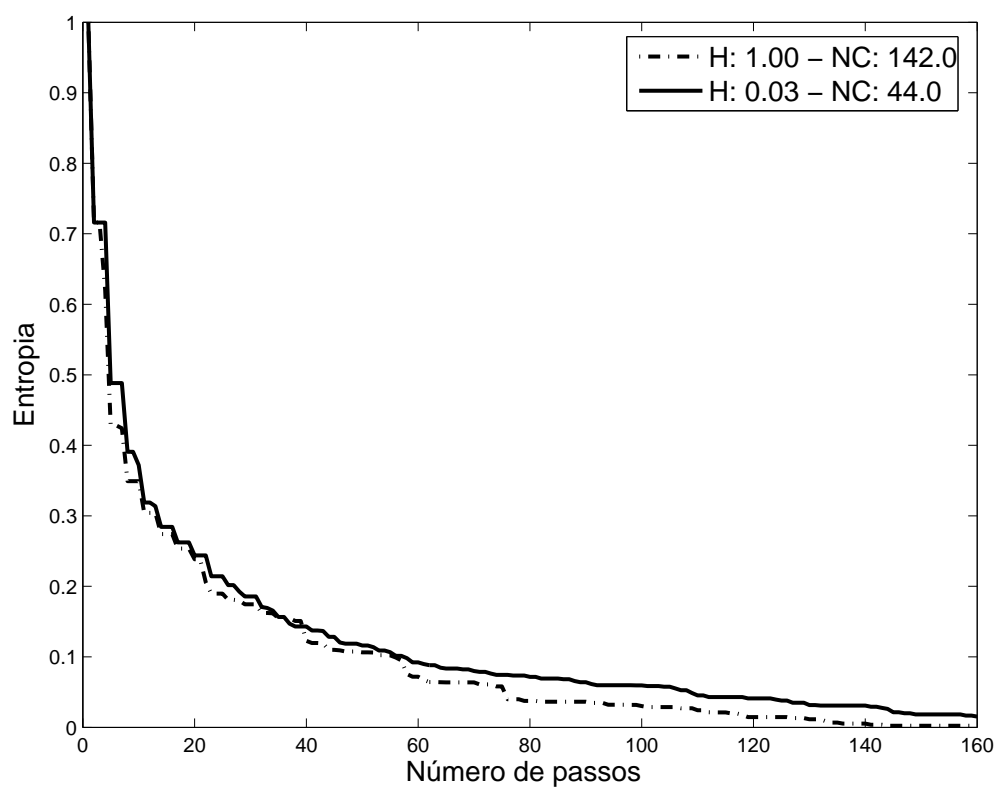

(a)

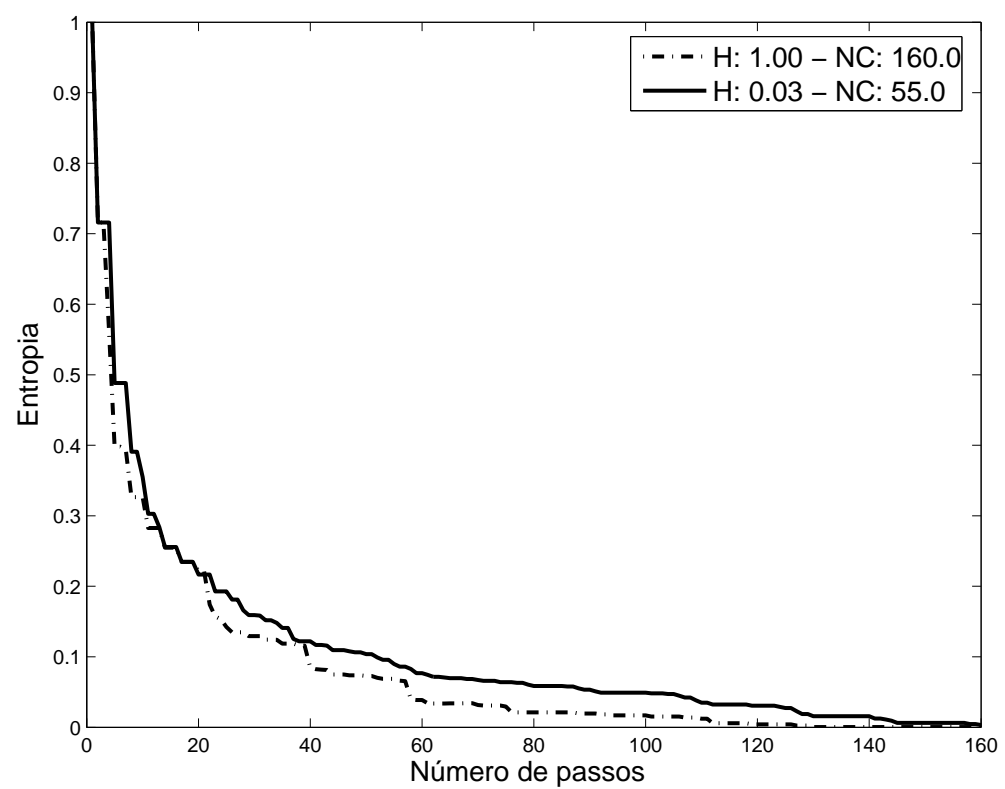

(b)

Figura 7.26: Comparação entre técnicas mais e menos comunicativas com oito robôs no ambiente de corredores da Figura 7.1(c). (a) Detecção. (b) Multidetecção. 


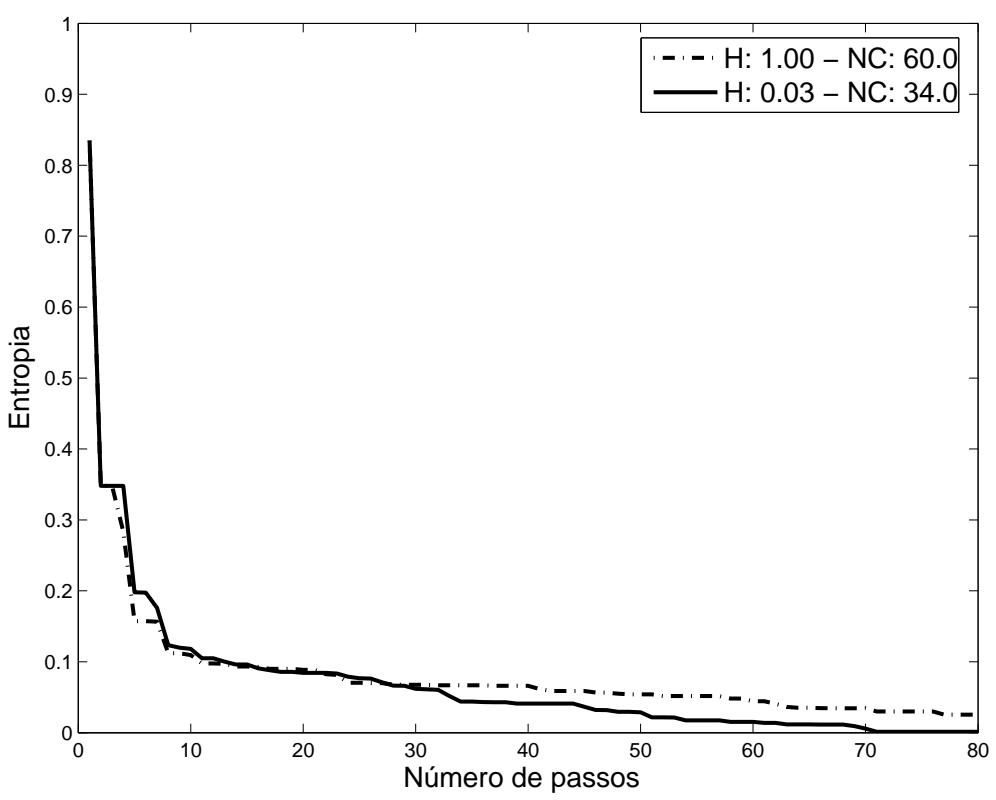

(a)

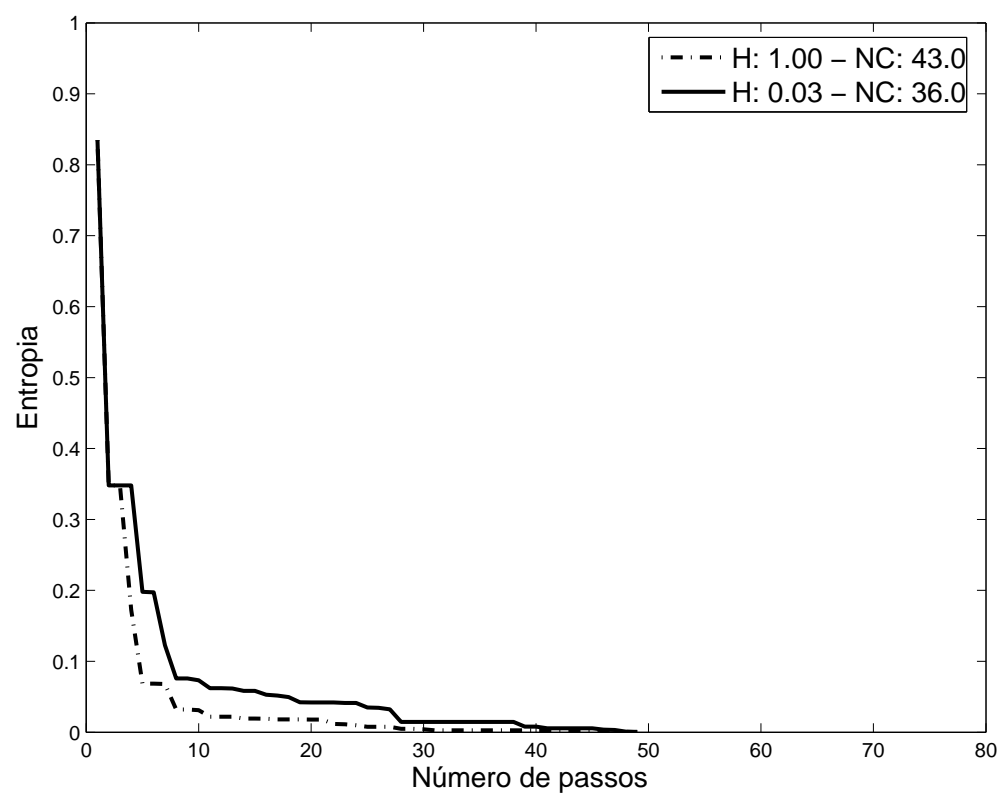

(b)

Figura 7.27: Comparação entre técnicas mais e menos comunicativas com dez robôs no ambiente de salas da Figura 7.1(d). (a) Detecção. (b) Multidetecção. 
as crenças de posturas. Além disso, se estas informações são obtidas através dos casos de detecção identificados, necessitando de troca de mensagens entre os robôs, há um aumento também na quantidade de informação comunicada. Uma forma de restringir a troca de mensagens, permitindo comunicação apenas quando há informação útil, reduz o tempo de processamento e demanda de comunicação, sem afetar em muito a acurácia nos resultados da localização.

Por fim, em relação às técnicas existentes de localização para multirrobôs cooperativos, as melhorias propostas nesta tese mostraram-se eficazes, contribuindo para redução dos erros de localização. 


\section{Conclusões e Trabalhos Futuros}

Neste capítulo são apresentadas as considerações finais desta tese. O objetivo principal da tese é propor uma solução para o problema de localização para multirrobôs cooperativos, que contribua para melhorar a acurácia das estimativas de posturas de todos os robôs do grupo. Como resultado deste objetivo foi proposta a LMMC, que é uma técnica de localização para multirrobôs cooperativos que se baseia na localização de Markov.

A proposta da LMMC inclui a formulação do modelo geral de detecção que engloba as atualizações de crenças de posturas utilizando informação de detecção positiva, propagação de detecção positiva, detecção negativa e multidetecção. Além disso, foi necessário propor o modelo de comunicação, responsável pela troca de mensagens entre os robôs. Este modelo de comunicação utiliza um protocolo de comunicação proposto para a LMMC, que considera as novas formas de atualização de posturas pertencentes ao modelo geral de detecção.

A investigação inicial do trabalho foi buscar novas formas de melhorar a qualidade de estimativa de postura dos robôs através da cooperação, ou seja, troca de informações relativas à localização entre os robôs. Em seguida, buscou-se maneiras de reduzir a quantidade de informação comunicada entre os robôs, sem, no entanto, aumentar o erro de localização. A solução encontrada foi restringir a comunicação baseada em um critério de utilidade da informação comunicada. O critério adotado foi o valor de entropia da crença de postura do robô.

Os experimentos realizados mostraram que a LMMC proposta apresenta melhores resultados, ou seja, estimativas de posturas mais acuradas, quando comparada com a técnica anteriormente proposta por Fox (2000). 


\subsection{Principais Contribuições e Limitações}

A contribuição principal da tese foi a proposta da LMMC, que gerou várias outras contribuições secundárias. Entre as contribuições alcançadas no decorrer da tese, as que resultaram em publicações foram:

- Proposta de um modelo de propagação de detecção positiva e sua incorporação na LMM (ODAKURA; COSTA, 2005).

- Proposta de um modelo de deteç̧ão negativa, bem como sua incorporação na LMM (ODAKURA; COSTA, 2006b).

- Proposta de um modelo de multidetecção, e sua incorporação na LMM (ODAKURA; COSTA, 2006a).

- Proposta de redução de comunicação entre os robôs (ODAKURA; COSTA, 2007).

Algumas limitações do trabalho:

- A atualização da crença de postura utilizando o modelo de detecção negativa só pode oferecer uma melhora na qualidade da estimação relacionada à configuração do ambiente, ou seja, apresenta melhores resultados quando o ambiente é ambíguo e os robôs não se encontram constantemente. Desta forma, nem sempre o custo computacional requerido por esse procedimento é justificado.

- A atualização da crença de postura utilizando o modelo de propagação da detecção positiva também é dependente do ambiente e da ambiguidade nas crenças de posturas dos robôs para apresentar uma melhora na acurácia das posturas estimadas. Da mesma forma, nem sempre o custo computacional requerido por esse procedimento é justificado.

- A multidetecção precisa que cada robô informe seu valor de entropia e o conjunto de robôs por ele detectados para todos os outros robôs do grupo, para que só então os robôs envolvidos na detecção possam montar, de forma distribuída, o gráfico de onde se extrai a ordem de atualização das posturas. Assim, esse procedimento exige uma grande quantidade de troca de mensagens.

- O protocolo de comunicação com redução de comunicação necessita de mensagens adicionais para informar o valor de entropia do robô que transmite 
a informação de localização, para que o robô receptor da mensagem possa decidir se aceita ou não a informação. Apesar de ser uma mensagem curta, este procedimento também sobrecarrega um pouco mais a comunicação.

- A movimentação dos robôs deve ser sincronizada, sendo que todos os robôs que atualizam suas posturas com informação do grupo em um determinado momento devem permanecer parados até que todas as atualizações sejam efetuadas. Este fato, em um ambiente multirrobôs, nem sempre é aceitável.

- A representação fatorada, por ser uma aproximação da realidade, exige que, após a atualização por uma detecção, outras detecções sejam evitadas por um determinado número de atualizações da postura. Este é problema que deve sempre ser contornado.

\subsection{Trabalhos Futuros}

Entre os trabalhos futuros está a implementação da técnica proposta em robôs reais, sendo necessário para isto, a utilização de algum algoritmo de localização mais eficiente do que a LM, como o FP.

Deve-se também estudar alguma forma de minimizar a limitação em relação à necessidade de sincronização dos robôs no momento das atualizações com informações de detecções.

Uma outra possibilidade é explorar alguma forma de pré-processamento da crença de posturas dos robôs, extraindo informação de regiões no ambiente e medindo as certezas e incertezas nas mesmas. Desta forma, robôs enviariam apenas mensagens contendo informações certas sobre as partes do ambiente que sejam de interesse do robô que recebe a mensagem. Isto possibilitaria redução no tamanho das mensagens. Além disso, deve-se explorar técnicas ativas de localização, uma vez que a abordagem desenvolvida nesta tese é puramente passiva. Essa pró-atividade pode se manifestar tanto no controle das ações de movimento para colher diferentes informações do ambiente que possam contribuir na localização, quanto iniciativa da comunicação requisitando, dos outros membros do grupo, informações específicas para aumentar a certeza de sua localização. Da mesma forma esta idéia pode ser expandida visando definir estratégias de atuação do grupo como um todo para atingir a acurácia desejada na localização no menor tempo e espaço explorado possível.

Apesar destas questões em aberto, a proposta aqui apresentada fornece uma 
sólida base que direciona a comunicação durante uma localização para multirrobôs cooperativos. Os experimentos realizados em ambientes simulados demonstraram que a proposta pode conduzir a resultados significativamente melhores de localização quando comparada à abordagem com detecção única, e ainda com uma menor quantidade de mensagens trocadas entre os robôs. 


\section{Referências Bibliográficas}

ALVARES, L. O.; SICHMAN, J. S. Introdução aos sistemas multiagentes. In: XVII Congresso da Sociedade Brasileira de Computação - CSBC'97. Brasília: SBC, 1997. p. 1-40. Jornada de Atualização em Informática - XVI JAI.

ARULAMPALAM, M. S.; MASKELL, S.; GORDON, N.; CLAPP, T. A tutorial on particle filters for online nonlinear/nonGaussian Bayesian tracking. IEEE Transactions on Signal Processing, v. 50, n. 2, p. 174-188, Fevereiro 2002.

BORENSTEIN, J.; EVERETT, B.; FENG, L. Navigating Mobile Robots: Systems and Tecnhiques. Wellesley, MA: A. K. Peters, Ltd, 1996. Disponível em: http://www-personal.engin.umich.edu/ johannb/my_book.htm, Acesso em: 10/05/04.

BOYEN, X.; KOLLER, D. Tractable inference for complex stochastic processes. In: Proceedings of the Fourteenth Annual Conference on Uncertainty in Artificial Intelligence - UAI'98. Madison, Wisconsin: Morgan Kaufmann, 1998. p. 33-42.

BOYEN, X.; KOLLER, D. Exploiting the architecture of dynamic systems. In: Proceedings of 16th National Conference on Artificial Intelligence - AAAI'99. Orlando, Florida: AAAI Press, 1999. p. 313-322.

CAMBRIDGE. Cambridge Dictionaries Online. 2006. Disponível em: http://dictionary.cambridge.org, Acesso em: 10/05/06.

CHAIB-DRAA, B.; DIGMUM, F. Trends in agent communication language. Computational Intelligence, v. 2, n. 5, 2002.

CHOSET, H.; LYNCH, K. M.; HUTCHINSON, S.; KANTOR, G.; BURGARD, W.; KAVRAKI, L. E.; THRUN, S. Principles of robot motion: theory, algorithms, and implementation. Cambridge Massachusetts: MIT Press, 2004.

COHEN, P. R.; LEVESQUE, H. J. Communicative actions for artificial agents. In: International Conference on Multi-Agents Systems - ICMAS'95. San Francisco, CA: AAAI Press, 1995. p. 65-72. 
CROWLEY, J. L. Mathematical foundations of navigation and perception for an autonomous mobile robot. In: Workshop on Reasoning with Uncertainty in Robotics. Amsterdam: Springer-Verlag, 1995. (Lecture Notes In Computer Science, v. 1093), p. 9-51.

CROWLEY, J. L.; DEMAZEAU, Y. Principles and techniques for sensor data fusion. Signal Processing, v. 32, n. 1-2, p. 5-27, Maio 1993.

DUDEK, G.; JENKIN, M. Computational principles of mobile robotics. 1 ed. Cambridge, UK: Cambridge University Press, 2000.

ENGELEN, R. A. van. Approximating Bayesian belief networks by arc removal. IEEE Transactions on Pattern Analysis and Machine Intelligence, v. 19, n. 8, p. 916-920, Agosto 1997.

FOX, D. Markov localization: a probabilistic framework for mobile robot localization and navigation. Tese (Doutorado) — University of Bonn, 1998.

FOX, D. Kld-sampling: adaptive particle filters. Advances in Neural Information Processing Systems - NIPS, 2002.

FOX, D.; BURGARD, W.; DELlAERT, F.; THRUN, S. Monte Carlo localization: efficient position estimation for mobile robots. In: Proceedings of the Sixteenth National Conference on Artificial Intelligence - AAAI'99. Orlando, Florida: AAAI Press, 1999.

FOX, D.; BURGARD, W.; KRUPPA, H.; THRUN, S. A probabilistic approach to collaborative multi-robot localization. Autonomous Robots, v. 8, n. 3, 2000.

FOX, D.; BURGARD, W.; THRUN, S. Markov localization for mobile robots in dynamic environments. Journal of Artificial Intelligence Research, v. 11, p. 391-427, 1999.

GELB, A. (Ed.). Applied Optimal Estimation. Fourteenth. Cambridge, MA: The MIT Press, 1996.

GROSS, H. M.; KOENIG, A.; BOEHME, H. J.; SCHROETER, C. Vision-based Monte Carlo self-localization for a mobile service robot acting as shopping assistant in a home store. In: Proceedings of IEEE/RSJ International Conference on Intelligent Robots and Systems - IROS'02. Lausanne, Switzerland: IEEE Press, 2002. p. 256-262. 
GUTMANN, S.; FOX, D. An experimental comparison of localization methods continued. In: Proceedings of the IEEE/RSJ International Conference on Intelligent Robots and Systems - IROS'02. Lausanne, Switzerland: IEEE Press, 2002.

HOFFMANN, J.; SPRANGER, M.; GOHRING, D.; JUNGEL, M. Making use of what you don't see: Negative information in Markov localization. In: IEEE/RSJ International Conference on Intelligent Robots and Systems - IROS'05. Edmonton, Alberta, Canadá: IEEE Press, 2005. p. 854-859.

HOWARD, A.; MATARIC, M.; SUKHATME, G. Localization for mobile robot teams using maximum likelihood estimation. In: IEEE/RSJ International Conference on Intelligent Robots and Systems - IROS'02. Switzerland: IEEE Press, 2002. p. $434-459$.

HOWARD, A.; MATARIC, M.; SUKHATME, G. Putting the 'i' in 'team': an egocentric approach to cooperative localization. In: IEEE International Conference on Robotics and Automation - ICRA'03. Taipei, Taiwan: Kluwer Academic Publishers, 2003. p. 14-19.

JENSFELT, P. Approachs to mobile robot localization in indoor environments. Tese (Doutorado) - Royal Institute of Technology, Stockholm, Sweden, 2001. Disponível em: http://www.nada.kth.se/ patrick/publications/phd.html, Acesso em: $12 / 09 / 2002$.

KALMAN, R. E. A new approach to linear filtering and prediction problems. Journal of Basic Engineering, Mar 1960.

$\mathrm{KOCH}, \mathrm{W}$. On negative information in tracking and sensor data fusion: discussion of selected examples. In: Seventh International Conference on Information Fusion. Stockholm, Sweden: International Society of Information Fusion, 2004. p. 91-98.

KOLLER, D.; FRATKINA, R. Using learning for approximation in stochastic processes. In: Proceedings fo the 15th International Conference on Machine Learning - ICML'98. San Francisco, CA: Morgan Kaufmann, 1998. p. 287-295.

KRISTENSEN, S.; JENSFELT, P. An experimental comparison of localisation methods. In: Proceedings of the IEEE/RSJ International Conference on Intelligent Robots and Systems - IROS'03. Las Vegas, EUA: IEEE Press, 2003. p. 992-997. 
KRÖSE, B.; BUNSCHOTEN, R. Probabilistic localization by appearance models and active vision. In: Proceedings of the IEEE International Conference on Robotics and Automation - ICRA'99. Detroit, MI, USA: IEEE Press, 1999. p. 2255-2260.

KRÖSE, B.; VLASSIS, N.; BUNSCHOTEN, R.; MOTOMURA, Y. A probabilistic model for appearance-based robot localization. Image and Vision Computing, v. 19, p. 381-391, 2001.

KURAZUME, R.; NAGATA, S.; HIROSE, S. Cooperative positioning with multiple robots. In: IEEE International Conference on Robotics and Automation ICRA'94. San Diego, CA: IEEE Press, 1994. p. 1250-1257.

LABROU, Y.; FININ, T.; PENG, Y. Agent communication languages: the current landscape. IEEE Intelligent Agents, p. 45-52, Março/Abril 1999.

LEONARD, J.; DURRANT-WHYTE, H. Mobile robot localization by tracking geometric beacons. IEEE Transactions on Robotics and Automation, v. 7, n. 3, p. 376-382, June 1991.

LIVATINO, S.; MADSEN, C. B. Autonomous robot navigation with automatic learning of visual landmarks. In: 7th International Symposium on Intelligent Robotic System - SIRS'99. Coimbra, Portugal: [s.n.], 1999. p. 419-428.

MADHAVAN, R.; FREGENE, K.; PARKER, L. E. Distributed heterogeneous outdoor multi-robot localization. In: IEEE International Conference on Robotics and Automation - ICRA'02. San Diego, CA: IEEE Press, 2002.

MAYBECK, P. S. Stochastic models, estimation, and control. New York: Academic Press, 1979.

MORAVEC, H. P.; ELFES, A. High-resolution maps from wide angle sonar. In: Proceedings of IEEE International Conference on Robotics and Automation. St. Louis, Missouri, USA: IEEE, 1985. p. 116-121.

MURPHY, R. Introduction to AI Robotics. Cambridge, MA: MIT Press, 2000.

MUTAMBARA, A. G. O. Decentralized Estimation and Control for Multisensor Systems. London: CRC Press, 1998.

NEHMZOW, U. Mobile Robotics: A Practical Introduction. Berlin, Heidelberg: Springer Verlag, 1999. 
NG, B.; PESHKIN, L.; PFEFFER, A. Factored particles for scalable monitoring. In: Proceedings of the 18th Conference in Uncertainty in Artificial IntelligenceUAI'02. Edmonton,Canadá: Morgan-Kaufmann, 2002. p. 370-377.

ODAKURA, V.; COSTA, A. H. R. Cooperative multi-robot localization: using communication to reduce localization error. In: International Conference on Informatics in Control, Automation and Robotics - ICINCO'05. Barcelona: INSTICC Press, 2005. p. 88-93.

ODAKURA, V.; COSTA, A. H. R. Multidetection in multirobot cooperative localization. In: First IFAC Workshop on Multivehicle Systems - MVS'06. Salvador - BA: [s.n.], 2006. p. 19-24.

ODAKURA, V.; COSTA, A. H. R. Negative information in cooperative multirobot localization. In: Advances in Artificial Intelligence - IBERAMIA-SBIA 2006. Ribeirão Preto - SP: Springer, 2006. LNAI 4140, p. 552-561.

ODAKURA, V.; COSTA, A. H. R. Efficient communication strategy for cooperative multirobot localization. In: Workshop on Multirobotic Systems for Societal Applications - 200\%. [S.l.: s.n.], 2007. No prelo.

PENEDO, C.; PAVÃO, J.; LIMA, P.; RIBEIRO, M. I. Markov localization in the robocup simulation league. In: Encontro Científico do $3^{\circ}$ Festival Nacional de Robótica, ROBOTICA 2003. Lisboa: [s.n.], 2003.

REKLEITIS, I. M. A particle filter tutorial for mobile robot localization. Quebec, 2004

REKLEITIS, I. M.; DUDEK, G.; MILIOS, E. E. Multi-robot cooperative localization: a study of tradeoffs between efficiency and accuracy. In: IEEE/RSJ International Conference on Intelligent Robots and Systems - IROS'O2. Switzerland: IEEE Press, 2002.

ROUMELIOTIS, S. I.; BEKEY, G. A. An extended Kalman filter for frequent local and infrequent global sensor data fusion. In: International Symposium on Intelligent Systems and Advanced Manufacturing - SPIE'9\%. [S.l.: s.n.], 1997.

ROUMELIOTIS, S. I.; BEKEY, G. A. Distributed multirobot localization. IEEE Transactions on Robotics and Automation, v. 18, n. 2, p. 781-795, October 2002.

RUSSELL, S.; NORVIG, P. Artificial Intelligence: A Modern Approach. New Jersey: Prentice Hall, 1995. (Artificial Intelligence). 
SÄRKKÄ, S.; TAMMINEN, T.; VEHTARI, A.; LAMPINEN, J. Probabilistic methods in multiple target tracking. Finlândia, 2004.

SCHMITT, T.; HANEK, R.; BEETZ, M.; BUCK, S.; RADIG, B. Cooperative probabilistic state estimation for vision-based autonomous mobile robots. IEEE Transactions on Robotics and Automation, v. 18, n. 2, p. 670-684, October 2002.

SIEGWART, R.; NOURBAKHSH, I. R. Introduction to autonomous mobile robots. Cambridge, Massachusetts: MIT Press, 2004.

SIMMONS, R.; KOENIG, S. Probabilistic robot navigation in partially observable environments. In: Proceedings of the International Joint Conference on Artificial Intelligence - IJCAI'95. Montréal, Québec, Canadá: Morgan Kaufmann, 1995. p. 1080-1087.

SMITH, A. F. M.; GELFAND, A. E. Bayesian statistics without tears: a sampling-resampling perspective. The American Statistician, v. 46, n. 2, p. 84-88, May 1992.

SPLETZER, J. R.; TAYLOR, C. J. A bounded uncertainty approach to multirobot localization. In: IEEE/RSJ International Conference on Intelligent Robots and Systems - IROS'03. Las Vegas, Nevada: IEEE Press, 2003.

TABUADA, P.; PAPPAS, G. J.; LIMA, P. Feasible formations of multi-agent systems. In: Proceedings of the American Control Conference. Arlington, VA: [s.n.], 2001. p. 56-61.

THOMPSON, S.; ZELINSKY, A.; SRINIVASAN, M. Automatic landmark selection for navigation with panoramic vision. In: Proceedings of Australian Conference on Robotics and Automation - ACRA'99. Australia: [s.n.], 1999.

THRUN, S. Bayesian landmark learning for mobile robot localization. Machine Learning, v. 33, n. 1, p. 41-76, 1998.

THRUN, S. Particle filters in robotics. In: Proceedings of Uncertainty in Artificial Intelligence - UAI'02. San Francisco, CA: Morgan Kaufmann, 2002.

THRUn, S.; BURGARD, W.; FOX, D. Probabilistic robotics. Cambridge, Massachusetts: MIT Press, 2005.

THRUN, S.; FOX, D.; BURGARD, W.; DELlAERT, F. Robust Monte Carlo localization for mobile robots. Artificial Intelligence, v. 128, p. 99-141, 2001. 
ULRICH, I.; NOURBAKHSH, I. Learning task-relevant features from robot data. In: Proceedings of the IEEE International Conference on Robotics and Automation - ICRA'00. San Francisco, CA: IEEE Press, 2000. p. 1023-1029.

WOOLDRIDGE, M.; JENNINGS, N. R. Intelligent agents: theory and practice. Knowledge Engineering Review, 1995. 


\section{Índice Remissivo}

arquitetura centralizada, 38

arquitetura descentralizada, 38

arquitetura distribuída, 38

cinemática direta, 11

cinemática inversa, 11

direção diferencial, 11

direção síncrona, 12

entropia, 62

exploração, 14

Filtro de Kalman, 20

Filtro de Kalman Estendido, 22

Filtro de Partículas, 30

fusão de informações, 38

localização ou auto-localização

localização baseada puramente em marcos, 15

localização de Markov, 26

localização ou auto-localização

com mapa, 16

sem mapa, 16

localização ou auto-localização

global ou absoluta, 15

localização baseada puramente em dead reckoning, 14

localização ou auto-localização, 8

incremental, localização local ou rastreamento de posição, 15

localização baseada em marcos, 15

não probabilísticos, 16

probabilísticos, 16

utilizando sensores externos, 16 utilizando sensores internos, 16

utilizando sensores internos e externos, 16

localização para multirrobôs cooperativos, 37

mapa, 8, 12

grade de ocupação, 13

métrico, 13

mapa geométrico, 13

mapa topológico, 13

mapeamento ou construção de mapas, 14

modelo de detecção, 48

modelo de comunicação, 69

modelo de detecção negativa, 57

modelo de movimento, 19

modelo de observação, 19

modelo de propagação de detecção positiva, 59

modelo geral de deteç̧ão, 56

multidetecção, 60

multirrobôs

heterogêneo, 39

homogêneo, 39

navegação, 7

planejamento de caminho, 8

posição, 14

postura, 14

absoluta, 39

relativa, 39

protocolo de comunicação, 72 
redução de comunicação, 75

robô, 6

robô móvel, 6

robô móvel autônomo, 7

sensores externos, 10

laser, 10

câmera, 10

infravermelho, 10

sonar, 10

sensores internos, 9

bússola, 9

inercial, 9

odômetro, 9

sistema de coordenadas do sensor, 8

sistema de coordenadas do ambiente ou

sistema de coordenadas global,

8

sistema de coordenadas do robô, 8

sistema de referência, 8

teste $t$ de Student, 84

tipo de movimento

alternado, 39

tipo de movimento, 39

simultâneo, 39 